WORKING PAPER · NO. 2020-155

Reversing the Resource Curse: Foreign Corruption Regulation and Economic Development

Hans B. Christensen, Mark Maffett, and Thomas Rauter

DECEMBER 2020

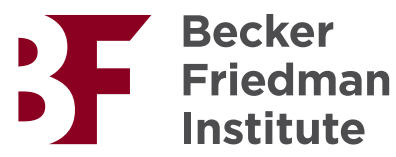




\title{
Reversing the Resource Curse: Foreign Corruption Regulation and Economic Development
}

\author{
By Hans B. Christensen, Mark Maffett, and Thomas Rauter*
}

December 2020

\begin{abstract}
We examine whether foreign corruption regulation reduces corruption and increases the local economic benefits of resource extraction. After a mid-2000s increase in enforcement of the US Foreign Corrupt Practices Act (FCPA), economic activity (measured by nighttime luminosity) increases by $14 \%$ (3\%) in African communities within a 10- (25-) kilometer radius of resource extraction facilities whose owners are subject to the FCPA. Local perceptions of corruption decline by $8 \%$. Consistent with changes in existing extraction firms' business practices contributing to the increase in development, the association between resource production, instrumented by world commodity prices, and local economic activity increases by $40 \%$.
\end{abstract}

Keywords: Foreign Corruption Regulation; Foreign Corrupt Practices Act (FCPA); Economic Development; Natural Resource Extraction

JEL Classification: F50; F60; K2; M4; O1

\footnotetext{
* University of Chicago Booth School of Business, 5807 South Woodlawn Avenue Chicago, IL 60637 (hans.christensen@chicagobooth.edu; mark.maffett@chicagobooth.edu; thomas.rauter@chicagobooth.edu). We thank Mia Giuriato and Ginha Kim for outstanding research assistance. We appreciate helpful comments from Ray Fisman, Ben Olken, Angela Reitmaier (Transparency International), Silvia Vannutelli, and workshop participants at the Arizona State University, the University of Chicago, the University of Mannheim, and the Early Insights in Accounting Webinar. We thank Nicola Coniglio and Adnan Seric for sharing the UNIDO African Investor Survey data. We gratefully acknowledge financial support from the University of Chicago Booth School of Business. This work is also supported by the Accounting Research Center, the Asness Junior Faculty Fellowship, the David G. Booth Faculty Fellowship, the IBM Corporation Faculty Fellowship, the John E. Jeuck Faculty Fellowship, and the Neubauer Family Faculty Fellowship at the University of Chicago Booth School of Business.
} 


\section{Introduction}

Large natural-resource endowments are often an economic boon for wellgoverned countries but a burden for those with weak political institutions, a phenomenon known as the "political resource curse" (Mehlum et al. 2006; Armand et al. 2020). In the presence of weak political institutions, the fiscal revenue windfalls from abundant natural resources create opportunities for corrupt government officials to extract rents and divert funds from the local economy (Robinson et al. 2006). With varying degrees of success, policymakers have tried to combat the harmful effects of natural resources in high-corruption-risk countries by strengthening local institutions and governance (e.g., by implementing domestic corruption laws and tying aid disbursements to a country's corruption record). Yet, foreign multinational firms, which are typically outside local governments' regulatory reach, are often complicit in bad governance and corruption (e.g., Guidolin and Ferrara 2007). Recognizing the costs of corruption in the developing world, governments in many developed countries have enacted foreign corruption regulations to curb firms' corrupt business practices abroad (e.g., Karpoff et al. 2017; Zeume 2017) — the most prominent and widely enforced being the US Foreign Corrupt Practices Act (FCPA). In this paper, we examine how foreign corruption regulation, in the form of a significant increase in US FCPA enforcement, affects economic growth in resource-rich areas of Africa.

If the FCPA reduces corruption and mitigates the negative aspects of resource extraction, such as inefficient resource allocation and the reinforcement of extractive political regimes, it could foster increased economic growth (Shleifer and Vishny 1993; Mauro 1995; Acemoglu and Robinson 2012; Ortiz-Ospina and Roser 2016). The FCPA could reduce corruption by directly increasing the costs of engaging in corrupt business practices for the multinational firms under its jurisdiction, as well as by indirectly increasing the incentives of these firms' local partners to avoid perceptions of corruption. FCPA compliance typically 
necessitates third-party evaluations of a contracting partner's corruption risk. Thus, local firms hoping to work with a firm under US jurisdiction have an incentive to avoid engaging in corrupt business practices, even when working with firms not subject to the FCPA. Given the sizable economic influence that extraction firms have on the surrounding communities, the FCPA's indirect effects on local firms could be significant.

Alternatively, prior research shows that one consequence of the compliance costs imposed by anti-corruption regulation is a reduction in foreign direct investment in high-corruption-risk countries (e.g., Beck et al. 1991; Hines 1995; Cuervo-Cazurra 2006; Christensen et al. 2020). Some argue that without the ability to bribe public officials it is hard to operate in areas with inefficient bureaucracies (Dutt and Traca 2016). If the costs imposed by foreign corruption regulation lead to a reduction in economically beneficial foreign investment, or the inability to pay bribes prevents regulated firms from competing against less efficient unregulated firms, foreign corruption regulation could hamper economic development. Ultimately, the net economic impact of foreign corruption regulation depends on how much the regulation decreases corruption, what regulated firms do instead of paying bribes, and whether the marginal investments forgone because of the regulation would have positively impacted development.

To speak to the impact of foreign corruption regulation, we examine changes in economic activity, as measured by nighttime light emissions, in African communities near large resource extraction facilities following a major increase in US FCPA enforcement in the mid-2000s. In our research design, we exploit the fact that 1) for reasons related to the feasibility of enforcement, FCPA cases are almost exclusively limited to firms under US jurisdiction that are headquartered in OECD countries (Christensen et al. 2020), and 2) following several prominent legal and regulatory changes (see Section 2), US enforcement of the FCPA against both US and non-US firms under US jurisdiction increased dramatically after 2004 (Martin 
et al. 2012; Olken and Pande 2012). Consequently, the enforcement shock likely impacts only the subset of African communities located near extraction facilities with a beneficial owner that is under US jurisdiction and headquartered in an OECD country after 2004. This feature of the setting allows us to estimate the treatment effect of the FCPA benchmarked against a control sample of likely unaffected communities (i.e., those located near an extraction facility with an owner that is not subject to the FCPA).

Our study focuses on the extraction industry in Africa, which is a powerful setting to examine the impact of foreign corruption regulation on economic development because resource extraction comprises a significant proportion of the African economy, is prone to corruption, and foreign corporations play a major role in these activities (Chuhan-Pole et al. 2017). We measure economic development using satellite images depicting the density of nighttime light emissions (i.e., luminosity) measured at levels of spatial stratification from 10- to 50-kilometers around an extraction facility. In rural Africa, luminosity is highly associated with economic activities, which provides us with reliable, uniform estimates of development in very localized areas (Henderson et al. 2012; Michalopoulos and Papaioannou 2014; Mamo et al. 2019). We combine the luminosity data with location, ownership, and commodity data for extraction facilities across Africa. This high degree of spatial resolution allows us to assess the impact of foreign corruption regulation at the local level, where it is most plausible that firm activities could affect economic development. To alleviate concerns about endogenous extraction site openings, closings, and ownership changes, we determine whether the facility's owner was subject to the FCPA in 2004 (i.e., before the FCPA enforcement increase).

Over a six-year period after 2004, we find that geographic areas with an extraction facility whose owner is subject to the FCPA gradually exhibit higher levels of economic activity relative to areas surrounding extraction sites that are not 
subject to the regulation. As we increase the radius of the cell surrounding the extraction site, the estimated average treatment effect monotonically declines; falling from a 14\% increase in luminosity within 10 kilometers of the facility (where the extraction industry plays a central role in the economy, directly employing nearly $20 \%$ of the total workforce) to an increase of $3 \%$ within 25 kilometers. Countries with weak political institutions before the FCPA enforcement increase, where prior research finds the resource curse's effects to be most pronounced (e.g., Mehlum et al. 2006), experience the largest increase in economic activity. Our results are robust to excluding luminosity emanating directly from the extraction facility, controlling for regional time trends, and controlling for changes in economic conditions in the headquarter country of the extraction-facility owner. We also find no evidence of a significant counterfactual treatment effect from being under US jurisdiction or being headquartered in an OECD country absent an increase in the threat of FCPA enforcement.

We find that employment levels in the local extraction sector remain relatively stable, suggesting that the observed positive association between foreign corruption regulation and economic development is not explained by a decline in activity in the extraction sector. Rather, the consistent level of activity suggests that the increase in development is driven by changes in the business practices of firms and local officials in and around the extraction sector. To assess this possibility, we estimate changes in perceived corruption and the direct contribution of resource production to local economic development.

To the extent that corruption negatively affects growth, the observed increase in local economic activity following the increase in FCPA enforcement could be explained (in part) by a reduction in corruption. For instance, foreign corruption regulation could make it more difficult for local officials to extract rents and thus improve resource allocation and increase the amount of extraction revenues that reach the local community. Consistent with this possibility, using 
microdata from the Afrobarometer survey, we find that individuals living near extraction sites whose owners are subject to the FCPA are 8\% less likely than individuals living in other areas to perceive their government as corrupt and 18\% more likely to be satisfied with their local government after 2004.

If, as a result of foreign corruption regulation, firms in (and connected to) the extraction sector stop paying (and soliciting) bribes and engaging in activities that have a negative economic impact on the local community, we expect the association between resource production and economic activity to increase. To mitigate concerns about the endogeneity of production decisions, we use variation in world commodity prices as an instrument for production quantities. Consistent with the increase in development being driven, at least in part, by changes in extraction firms' business practices, we find that the introduction of foreign corruption regulation increases the elasticity of luminosity to world commodity prices by $40 \%$ within a 10 -kilometer radius of an extraction site. The change in elasticity declines predictably as we increase the radius of the extraction area up to 50 kilometers. Additional analyses indicate that the extraction sector's increased contribution to local economic activity is not explained by ownership changes after 2004. These results, which condition the baseline association between foreign corruption regulation and economic activity on an exogenous shock to production, also help to alleviate the concern that a shock around 2005 (unrelated to the extraction sector) that differentially affects treated and non-treated cells could present an alternative explanation for our results.

Our findings contribute most directly to the literature on anti-corruption regulation. Most prior work focuses on foreign corruption regulation's impact on the operations of multinational corporations (e.g., Graham 1984, Beck et al. 1991; Hines 1995; Zeume 2017; Christensen et al. 2020; Rauter 2020; Sanseverino 2020). We instead provide evidence on how foreign corruption regulation impacts economic development in the host countries where bribes are paid and where the 
negative consequences of corruption are most acutely felt. Some prior studies examine the effects of domestic corruption regulation on corruption (Olken 2007; Ferraz and Finan 2008; Bobonis et al. 2016; Zamboni et al. 2018; Avis et al. 2016) and local firm behavior as well as economic growth (Colonnelli and Prem 2020). In contrast, we examine how foreign corruption regulation, originating in developed countries, affects local economic conditions in the developing world. Reducing foreign corruption by multinational corporations is likely more difficult than prosecuting domestic corruption because it is challenging for local law enforcement, especially in developing countries with weak institutions, to gather evidence and sanction perpetrators located abroad. Our evidence indicates that, despite any increase in the costs of operating in high-corruption-risk countries, foreign corruption regulation stimulates economic development by changing how foreign firms operate in these regions.

Our results are also related to a large literature that examines the impact of resource extraction on economic development, beginning with the finding by Sachs and Warner (1995) that countries rich in natural resources tend to experience lower growth (i.e., the "resource curse"). Although most recent work does not support an overall negative impact of natural resources on economic growth (e.g., Smith 2015; Mamo et al. 2019), many argue that the local benefits from natural resources are less than one would expect and that the political institutions of host countries explain the divergent outcomes (e.g., Mehlum et al. 2006; Robinson et al. 2006; Humphreys et al. 2007; Sarr et al. 2011). Our results suggest that anti-corruption regulation imposed on multinational corporations by countries with strong institutions (in this case, the US) can increase the extraction sector's contribution to local economic development in countries with weak political institutions. This is important because developing countries may not have the institutional strength or political will to address misconduct by multinational corporations themselves. 


\section{Institutional Details and their Connection to the Research Design}

Estimating the impact of foreign corruption regulation on economic development is challenging because corruption is unobservable and its effect on economic activity is difficult to isolate absent clearly defined treatment and control groups. To overcome these challenges, we examine a major increase in the enforcement of foreign corruption regulation that affects only a subset of African resource extraction facilities and measure economic activity based on nighttime light emissions in highly geographically localized areas around these facilities.

A mid-2000s increase in extraterritorial FCPA enforcement likely significantly increased the costs of engaging in corruption for firms under US jurisdiction (Olken and Pande 2012). Although Congress enacted the FCPA in 1977, because of a lack of domestic support and limited international cooperation, the law was not widely enforced for over two decades, particularly against non-US firms (Martin et al. 2012). Data from the Stanford Foreign Corrupt Practices Act Clearinghouse, reported in Internet Appendix Section IA1.1, provide evidence of a dramatic increase in FCPA enforcement beginning in 2005. From 1977 until 2004, there were 53 FCPA enforcement actions against corporations (fewer than 2 per year); from 2005 until 2017, there were 284 cases (more than 20 per year). For nonUS firms, the increase in enforcement was even more pronounced, growing from 4 enforcement actions from 1977 until 2004 to 97 cases from 2005 until 2017. As discussed in Internet Appendix Section IA1.1, a confluence of factors all occurring in 2004 help to explain the timing of this increase in FCPA enforcement, including (i) an expanded legal definition of bribery, (ii) the introduction of deferred and nonprosecution agreements in FCPA cases, and (iii) the enactment of the SarbanesOxley Act (Martin et al. 2012; Brewster 2017).

To assess when firms first broadly became aware of the increase in FCPA enforcement, we examine changes in investment flows to high-corruption-risk countries (see Internet Appendix Section IA1.2), which we expect, based on prior 
research, to adjust relatively quickly to any perceived increase in anti-corruption enforcement (Zeume 2017; Sanseverino 2020). Figure IA2 shows that foreign direct investment flows to high-corruption-risk countries decrease sharply starting in 2005, suggesting that multinational firms under FCPA jurisdiction were aware of (and responded to) the deterrent effect of the increase in FCPA enforcement soon after the 2004 legal and regulatory changes. Based on this evidence and the timing of the increase in enforcement actions, we use 2005 to mark the onset of the treatment period in our empirical analyses.

The FCPA's jurisdictional scope is expansive, and either the SEC and/or the DOJ can bring cases against US- and non-US-domiciled issuers, domestic concerns, and firms acting in US territory (SEC and DOJ 2012). Based on FCPA guidelines, we classify an extraction facility as being under FCPA jurisdiction if at least one of the facility's corporate owners has a stake of $20 \%$ or more and is: 1) headquartered in the US, 2) has an SEC-registered cross-listing on a US stock exchange, or 3) discloses an operating segment in the US. ${ }^{1}$ A $20 \%$ ownership stake generally provides the owner with significant influence, which is an important factor in determining culpability under the FCPA. We obtain information on the identity, ownership stakes, and headquarter countries of the ultimate owners of extraction sites from SNL Metals and Mining ("SNL") and Enverus International ("Enverus"). We collect data on US cross-listings from the websites of the major depository banks (Bank of New York and Citibank) and data on US reporting segments from Worldscope. We verify that a cross-listed firm is an SEC registrant through a search of 20-F and 40-F filings in the SeekEdgar database.

\footnotetext{
${ }^{1}$ Under international accounting standards, if a firm has a significant operational presence in another country, the firm must publicly disclose disaggregated financial information for operations in that country. For foreign firms that disclose a US segment, it is more likely that, if the firm commits an FCPA violation, that action will fall under US jurisdiction.
} 
Effective prosecution of non-US firms under the FCPA typically requires cooperation from foreign regulators. Likely for this reason, FCPA enforcement against non-US firms has been limited to firms headquartered in countries that have signed the legally binding Convention on Combating Bribery of Foreign Public Officials in International Business Transactions (i.e., the Anti-Bribery Convention). The Anti-Bribery Convention requires cooperation among signatory countries and has been signed by all OECD members and six non-members (as of the end of our sample in 2013) - for brevity, we refer to all signatory countries as "OECD countries." ${ }^{2}$ Of the 97 non-US firms targeted by an FCPA enforcement action between 2005 and 2017, only two were headquartered in a non-OECD country (Stanford FCPA Database 2020). Because enforcement of the FCPA has in practice been limited to firms headquartered in Anti-Bribery Convention signatory countries, we consider only owners that are under US jurisdiction and are also headquartered in an OECD country as being subject to the FCPA (i.e., treated). ${ }^{3}$

To avoid the possibility that our estimates reflect endogenous variation in ownership, we base our treatment assignment on data from 2004 and consider extraction facilities subject to the FCPA in 2004 to always be subject to the FCPA. About $15 \%$ of all extraction sites in our sample are treated (i.e., have at least one owner with significant influence that is subject to the FCPA, see Internet Appendix Section IA2 for details). The location of extraction facilities owned by a company subject to the FCPA is fairly dispersed across Africa (see Figure 1 Panel A).

We use the African extraction sector as our setting because, if foreign corruption regulation has an effect on high-corruption risk areas, the effect is likely to be particularly strong in this setting. Specifically, the African extraction sector is

${ }^{2}$ For a list of Anti-Bribery Convention signatory countries, see www.oecd.org.

${ }^{3}$ Although all OECD countries have their own foreign corruption regulations and some, such as Germany and the UK, have recently increased enforcement, the US accounts for $83 \%$ of all antibribery sanctions against legal entities from 1999 to 2018 (OECD 2019). 
prone to corrupt business practices and is a frequent target of FCPA enforcement after 2005. Survey data from the Afrobarometer in Table 1 Panel A show that residents of communities within $50 \mathrm{~km}$ of an extraction site are significantly more likely to perceive foreign businessmen as corrupt compared to residents not in the proximity of an extraction site. Of the 284 total FCPA enforcement actions between 2005 and 2017, 70 included FCPA violations in Africa (nearly 25\%), and 41 of these 70 cases (nearly 60\%) were against firms in the natural resource extraction industry (Stanford FCPA Database 2020).

The FCPA's potential impact on corruption extends beyond transactions involving firms directly subject to the FCPA. The FCPA also creates an incentive for local suppliers and contractors that want to work with firms subject to the regulation (e.g., construction firms) to avoid engaging in corrupt activities, even in transactions with firms not subject to the regulation. For example, besides prohibiting bribery, the FCPA also imposes recordkeeping requirements that force firms to ensure their internal control systems can prevent and detect improper payments. To ensure compliance with the FCPA's accounting provisions, firms typically perform due diligence of suppliers and service providers (Huskins 2008). This due diligence typically involves screening new and existing business partners for possible affiliations with high-corruption-risk individuals and companies that have a record of previously engaging in corrupt activities or have connections to government officials (SEC and DOJ 2012). Given these compliance requirements, prior involvement in corruption would almost certainly impede transactions with a firm subject to the FCPA. Because extraction firms are major purchasers of local services and materials in the communities around them, the indirect effects of the FCPA on local businesses could be significant. ${ }^{4}$

\footnotetext{
${ }^{4}$ One reason for foreign firms' local purchases is the common practice of imposing "local content obligations" on foreign businesses, which typically require foreign companies to source certain
} 
Because we expect the effect of FCPA enforcement to be strongest locally, our unit of observation is the circular geographic area with a radius of 10 to 50 kilometers around an active extraction facility (henceforth, a "cell"). We collect mine-level data from $S N L$ and oil-well data from Enverus. Both databases provide the latitude and longitude of extraction sites, which enables us to match these data to a particular cell and to assess the FCPA's impact at a highly geographically localized level, where, because of mineral extraction's significant economic importance, the regulation could significantly affect corruption levels. For instance, using occupational microdata from the 2004 Afrobarometer survey (see Section 4.1 for details), in Table 1 Panel B, we estimate that, within a 10-kilometer radius of an extraction site, $18 \%$ of the local workforce is employed in the extraction industry. This proportion monotonically decreases to $10 \%$ as the radius is extended to 50 kilometers. In communities not classified as extraction areas (i.e., those more than $50 \mathrm{~km}$ from an extraction facility), the fraction of mine workers is only $0.9 \%$.

To avoid treatment spillovers across oil wells, we drop blocks that are operated by multiple firms. ${ }^{5}$ If more than one commodity is extracted on the same site, that cell appears in the dataset as a separate observation for each commodity. We drop inactive mines, oil and gas wells, and wells located offshore. In Internet Appendix Section IA2, we provide details on each restriction's impact on the sample. In Internet Appendix Section IA3, we discuss the robustness of our results to alternative sampling procedures, including dropping overlapping extraction areas and keeping only commodities with the highest production value per facility.

Overall, our sample contains 487 mines of 18 minerals (673 mine-mineral pairs) and 113 oil and gas wells located across 34 African countries. Most of our

goods and services from local enterprises and provide training to their employees as a condition of their operating licenses (see UNCTAD 2012 for details).

${ }^{5}$ Blocks are geographic areas where firms with licenses can drill for oil. Host governments can award different portions of the same block to different firms, particularly if the block is large. 
extraction facilities are located in South Africa (48\%), followed by Libya (8\%), the Democratic Republic of Congo (5\%), and Zimbabwe (5\%). In Internet Appendix Section IA2, we report the sample composition by African country and region.

Internet Appendix Table IA2.2 reports the distribution of extraction facilities across resource types. Our sample includes facilities that extract 20 different commodities, with the largest concentration in gold (23\%), followed by coal $(14 \%)$, and oil (13\%). We map the geographic distribution of commodities throughout Africa in Figure 1 Panel B. As expected, individual resource types cluster geographically, but none of the five regions of Africa contain fewer than eight different minerals.

We measure economic development using the density of nighttime light emissions. GDP estimates based on national accounts and other common proxies for economic development are often measured with significant error in developing countries (Johnson et al. 2009) and are generally only available at the national level. In contrast, luminosity estimates are available at a much finer geographic specificity and allow for accurately estimating changes in economic growth at the subnational level (Henderson et al. 2011; Henderson et al. 2012; Michalopoulos and Papaioannou 2014). Compared to other economic development measures (e.g., GDP), luminosity reflects the level of economic activity more broadly. If the benefits of an increase in economic growth are highly concentrated, it is unlikely to significantly impact luminosity. Thus, the level of luminosity is more indicative of the overall well-being of people throughout the community.

We collect luminosity data from the United States Air Force Defense Meteorological Satellite Program (DMSP). DMSP satellites collect data on lowlight imaging for every location on the planet every night. The National Geophysical Data Center (NGDC) processes these data (e.g., by removing natural light sources and images obscured by cloud cover) and publishes the final, annualized data. We compute the cloud-free-observation weighted average over all 
stable nightlight pixels for each cell. Table 2 reports descriptive statistics for Luminosity across 10,318 cell-year observations from 2000 to 2013. ${ }^{6}$ Luminosity ranges from 0 (no light) to 63 (a highly developed urban area). Average Luminosity within 10 kilometers of an extraction site is 7.7 and monotonically decreases as the radius around the extraction site increases.

\section{Effect of Foreign Corruption Regulation on Economic Development}

\subsection{Main Results}

To examine how foreign corruption regulation affects economic development, we estimate the change in nighttime light emissions after the mid2000s increase in US FCPA enforcement in geographic cells with radii ranging from 10 to 50 kilometers around natural resource extraction facilities. Our generalized difference-in-differences design compares luminosity in cells with an extraction facility that has a controlling owner subject to the FCPA to cells where the extraction facility does not have an owner subject to the FCPA. Because economic activity likely responds gradually, we plot yearly coefficient estimates of the treatment effect from the following OLS regression:

$$
\text { Luminosity }_{c, t}=\beta_{1} F C R_{i} \times \text { Year }_{t}+\text { Fixed Effects }+\varepsilon_{c, t}
$$

Luminosity is the natural logarithm of the average luminosity in cell $c$ and year $t$ plus $1 .{ }^{7} F C R$ is an indicator equal to one if, in 2004, at least one extraction site owner (of 20\% or more) is subject to the FCPA (i.e., is under US jurisdiction and headquartered in an OECD country). Year is a set of indicators for each year of our sample period. We omit the indicator for 2004, which serves as the benchmark period. To control for differences in luminosity arising from time-invariant (or slow-moving) factors that are specific to each extraction site (e.g., geological

\footnotetext{
${ }^{6}$ Our sample ends in 2013 because the NGDC changed its processing methods in 2014.

7 To include observations with a value of zero and to account for the variable's skewness, we use the natural logarithm of Luminosity plus one in our analyses. We find similar results using an inverse hyperbolic sine transformation (see Table 3 and Table 5 Panel B) or dropping zeros and using Ln(Luminosity) as the dependent variable (see Internet Appendix Section IA3).
} 
conditions, property size), we include extraction-site-by-commodity fixed effects (Property $\times$ Commodity). We add Commodity $\times$ Year fixed effects to account for commodity-specific time trends. We test for statistical significance using Conley (1999) standard errors to account for spatial correlation within a 500-km radius and infinite serial correlation.

In Figure 2 Panel A, we graph the yearly $F C R \times$ Year coefficient estimates and their corresponding 95\% confidence intervals. In support of the parallel-trends assumption, treated and control cells have similar trends in luminosity before 2005 . Consistent with foreign corruption regulation increasing economic activity, between 2005 and 2010, treated cells exhibit a gradually increasing level of luminosity relative to control cells. After 2009, the treatment effect stabilizes at an approximately $20 \%$ higher level. In interpreting the economic significance, it is important to note that in this specification, we focus on the area in the immediate vicinity (i.e., a 10-kilometer radius) of the facility, where the extraction industry employs an estimated $18 \%$ of the cell's workforce.

To estimate the average post-2004 treatment effect and to simplify the reporting of sensitivity tests, we also present results based on a specification where we replace the individual Year indicators with a single Post 2004 indicator, which equals one for all years after 2004. Table 3 reports the results. In Column (1), the FCR $\times$ Post 2004 coefficient estimate is positive and statistically significant, indicating that economic activity increases by approximately $14 \%$ in the cells surrounding extraction facilities subject to the FCPA relative to cells that do not.

If the observed increase in luminosity is attributable to changes in the extraction sector, we expect the magnitude of the treatment effect to diminish as we increase the cell size and the facility becomes a less central part of economic activity within a particular cell. In Figure 2 Panel B, we graph the FCR $\times$ Post 2004 coefficient estimates and their corresponding 95\% confidence intervals for cells with radii from 10 to 50 kilometers. The $F C R \times$ Post 2004 coefficient estimate 
decreases monotonically in the length of the radius of the cell. The point estimates are positive and statistically significant for radii up to a distance of 25 kilometers. At a 25-kilometer radius, the coefficient on FCR $\times$ Post 2004 implies an increase in luminosity of approximately $3 \%$.

In Table 3 Columns (2) to (5), we present the results of four sensitivity tests. ${ }^{8}$ First, instead of adding one to Luminosity to account for zero-value observations, we use an inverse hyperbolic sine transformation. The estimated treatment effect in Column (2) increases from 13\% to approximately $18 \%$. Second, to ensure that we capture economic activity in the communities surrounding extraction sites rather than only for the extraction site itself, we exclude a onekilometer-radius cell around the extraction site. In Column (3), where we reestimate our baseline model on the donut-shaped 1-10 km area around the extraction site, we find that the estimated treatment effect remains positive, statistically significant, and only slightly attenuates. Third, in Column (4), we include Region $\times$ Year fixed effects to account for time-varying institutional and political factors (e.g., climate conditions, armed conflicts) that are correlated with Africa's five main geographic regions (shown in Figure 1). The estimated treatment effect increases from 0.136 to $0.141 .{ }^{9}$

Fourth, we examine placebo treatment effects for subsamples of our control group. Our treatment group consists of extraction facilities owned by firms under US jurisdiction headquartered in OECD countries. A potential concern is that either being under US jurisdiction or being located in an OECD country is associated with factors (unrelated to foreign corruption regulation) that change around 2005 and

\footnotetext{
${ }^{8}$ In Internet Appendix Section IA3, we report results for several additional sensitivity tests, including individually dropping each commodity, excluding overlapping extraction areas, and keeping only the main commodity for each facility.

${ }^{9}$ We do not include Country $\times$ Year fixed effects because the geographical clustering of commodities (see Figure 1 Panel B) severely limits the number of observations that would contribute to the FCR $\times$ Post 2004 coefficient estimate. See Internet Appendix Section IA2.3 for details.
} 
explain our results (e.g., a financial market shock). Fortunately, our control group, which includes firms under US jurisdiction headquartered in non-OECD countries and firms not under US jurisdiction headquartered in OECD countries, allows us to speak to the severity of this concern. US jurisdiction firms not headquartered in an OECD country are almost never targeted under the FCPA. Similarly, although the jurisdictional scope of the FCPA is broad and some treatment effect could be expected for all OECD-headquartered firms, firms that are not SEC-registered and do not have a US operating segment are substantially less likely to be targeted (Christensen et al. 2020). If the observed changes in luminosity are attributable to a factor associated with US jurisdiction or being headquartered in an OECD country, but unrelated to foreign corruption regulation, we would expect to observe similar treatment effects for these firms.

In Table 3 Column (5), we include separate interactions for USJ Non$O E C D \times$ Post 2004 and Non-USJ OECD $\times$ Post 2004. Consistent with the increase in economic activity being attributable to foreign corruption regulation, we find no evidence of a significant change in luminosity in areas where an extraction facility's owner is under US jurisdiction but not headquartered in an OECD country or where the owner is headquartered in an OECD country but not under US jurisdiction. Both coefficients are significantly different from the $F C R \times$ Post 2004 estimate (at the $10 \%$ level or higher). ${ }^{10}$

\subsection{Heterogeneity in Political Institutions}

Prior research finds that the effect of natural resources on economic development depends on the quality of local institutions (e.g., Mehlum et al. 2006;

\footnotetext{
${ }^{10}$ In Internet Appendix Section IA3.5, we present all of the results from Table 3 including these two additional interactions. In Internet Appendix Section IA3.6, we present results from an alternative approach to addressing concerns about macroeconomic shocks in the facility owner's home country where we control for observable macroeconomic conditions. This approach directly addresses selection on the observables we control for (e.g., GDP growth) and, to the extent the observable and unobservable factors are correlated, provides a way to gauge the magnitude of any potential effect of unobservable factors (Altonji et al. 2005).
} 
Robinson et al. 2006). Countries with strong institutions that promote political accountability tend to benefit more from their resource endowments because these institutions mitigate the rent-seeking opportunities that resource extraction can create. Accordingly, we expect to observe larger increases in economic development after the FCPA enforcement increase in countries with weak political institutions, where the political resource curse is likely most prevalent.

To test this prediction, we separately estimate Eq. (1) for countries with strong or weak political institutions based on the Center for Systemic Peace's Polity IV Democracy Index in 2004 (i.e., the year before the FCPA enforcement increase). The Polity $I V$ index ranks countries based on the strength of their political institutions on a scale from -10 (autocracy) to 10 (full democracy). We classify countries as strong-political-institution countries if their Polity $I V$ score is 6 or higher, the threshold for a democracy.

Figure 2 Panel $\mathrm{C}$ shows that, after the FCPA enforcement increase, the observed increase in economic activity is substantially larger in weak-politicalinstitution countries (the solid red line) compared to strong-institution countries (the dashed blue line). The regression results in Table 3 Columns (6) and (7) corroborate this finding - the treatment effect is about 25 percentage points larger in countries with weak political institutions (the difference between countries with weak and strong political institutions is statistically significant; $p$-value $=0.02$ ).

\subsection{Changes in the Size of the Extraction Sector}

The opportunity to obtain bribes can incentivize government officials to allow extraction firms to produce at levels that exceed what is optimal for the local economy. If foreign corruption regulation reduces the availability of bribes and decreases the incentives of officials to permit overproduction, the positive association between FCPA enforcement and local economic development could be explained by a shift in resources away from the extraction sector. Such an effect would reduce the extraction sector's direct contribution to local economic growth 
but could allow other sectors (e.g., agriculture) to thrive, potentially increasing the overall level of development.

In Internet Appendix Section IA4, we examine employment changes in the extraction sector. Inconsistent with a decline in extraction activity explaining the increase in development, results from this analysis provide no evidence of a decline in extraction-sector employment levels after the 2004 FCPA enforcement increase.

\subsection{Summary of Results}

To summarize, the evidence in this section indicates that local economic activity increases in cells around extraction facilities with owners subject to foreign corruption regulation, suggesting that the FCPA's corruption reducing effects outweigh any opposing effects arising from a reduction in economically beneficial investment. Consistent with foreign corruption regulation helping to reverse the political resource curse, the increase in economic activity is most pronounced in areas with weak political institutions. We find no evidence that the positive association between foreign corruption regulation and economic development is explained by a decline in activity in the extraction sector, suggesting that the observed increase in development is driven (at least in part) by a change in the business practices of firms and local officials in and around the extraction sector.

\section{Changes within the Extraction Sector}

To assess whether changes in the business practices of firms and local officials in and around the extraction sector (e.g., engaging in less corruption) can explain the observed increase in development, in this section, we estimate changes in perceived corruption and the contribution of extraction firms' activities to local economic growth.

\subsection{Perceived Corruption}

The observed increase in economic activity in extraction areas subject to foreign corruption regulation is consistent with a decline in corruption and an accompanying increase in the efficiency of resource allocation. However, 
providing evidence of a direct link is difficult, given that corruption is unobservable. Instead, we examine changes in a survey-based measure of local residents' perceptions of corruption. However, unlike the underlying level of corruption, the effect of foreign corruption regulation on corruption perceptions is not obvious. If the increase in FCPA enforcement leads to an increased awareness of corrupt activities, it is possible that the perceived level of corruption could increase even if the underlying level of corruption decreases. For this reason, we also examine satisfaction with the local government. If in the presence of foreign corruption regulation public officials can less easily extract bribes, they may be less inclined to prioritize extraction firms over other more socially beneficial sectors of the economy. Although it is less related to the underlying construct of interest, relative to perceived corruption, satisfaction with the local government is more easily observable by survey respondents and is less likely to be directly influenced by witnessing an increase in enforcement actions.

We collect sub-nationally geocoded data on corruption perceptions from the Afrobarometer survey. Afrobarometer, a non-partisan research institution, regularly conducts public opinion surveys at the individual level in more than 30 African countries. We use data from rounds one to six of the survey, a period that stretches from 1999 to 2015, and measure perceived corruption using answers to the question "How many of the following people do you think are involved in corruption: Government officials?" We define an indicator, Corrupt Government, equal to one if the response to the question is "most of them" or "all of them." To examine satisfaction with the local government, we use the answers to the question: "Do you approve or disapprove of the way the following people have performed their jobs over the past twelve months: Local government/official/assembly?" We define an indicator, Satisfaction with Local Government, equal to one if an individual responds "approve" or "strongly approve." 
We restrict the sample to survey respondents who live within 100 kilometers of an extraction facility. ${ }^{11}$ Our final sample covers the survey responses of 56,276 participants in 4,531 villages across 31 African countries between 1999 and 2015. In Internet Appendix Section IA5, we report the number of observations by country and survey round. Table 4 Panel A presents descriptive statistics. Approximately $18 \%$ of survey participants live in close proximity to an extraction site whose owner is subject to the FCPA. $44 \%$ of individuals perceive the government to be highly corrupt, and 53\% are satisfied with their local government. Roughly three-quarters of the survey responses were collected after $2004.49 \%$ of respondents are female, $44 \%$ live in urban areas, and their average age is 37 years old.

To examine how foreign corruption regulation affects corruption perceptions and satisfaction with the local government, we estimate the following OLS regression:

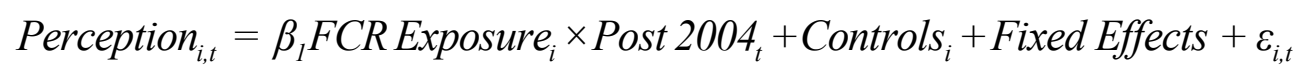

Perception is either Corrupt Government or Satisfaction with Local Government (as defined above) for individual $i$ in survey round t. FCR Exposure is an indicator equal to one if the closest extraction facility within $100 \mathrm{~km}$ of survey respondent $i$ is subject to the FCPA. Post 2004 is an indicator for survey rounds after 2004. We include controls for several individual characteristics that could be associated with perceptions, including gender (Female) because perceptions often differ across genders (e.g., Croson and Gneezy 2009; Melgar et al. 2010; D’Acunto 2020); Urban because individuals living in cities might more frequently interact with government officials (Hunt 2004; Mocan 2004); and age (Ln(Age)) to account for

\footnotetext{
${ }^{11}$ We use a larger radius $(100 \mathrm{~km})$ in this analysis because Afrobarometer does not survey the same villages across rounds (for the same reason, we do not include individual survey respondent or geographic area fixed effects in Eq. (2)). If we use a narrower radius (e.g., $25 \mathrm{~km}$ or $50 \mathrm{~km}$ ), few extraction areas enter our sample in both the pre- and post-periods. In untabulated analyses, we use radii of $25 \mathrm{~km}$ and $50 \mathrm{~km}$ and find evidence supporting an increase in satisfaction with the local government but little evidence of a reduction in corruption perceptions.
} 
intergenerational differences in perceptions (Torgler and Valev 2006). We include Region $\times$ Year fixed effects to account for time-varying political factors (e.g., corruption scandals) that are correlated with Africa's five main geographic regions. We add Commodity fixed effects to control for time-invariant or (slow-moving) differences in corruption perceptions across areas that extract different commodities. We cluster standard errors at the village level because individuals' perceptions are likely correlated within localities.

In Table 4 Panel $\mathrm{B}$, we report the regression results from estimating Equation (2). In Column (1), the $F C R \times$ Post 2004 coefficient estimate is negative, statistically significant, and indicates that individuals living near extraction sites whose owners are subject to the FCPA are $8 \%$ less likely to perceive their government as corrupt after 2004, compared to the pre-period average $(-0.043 / 0.548)$. In Column (2), we include control variables and find that, although the control-variable coefficient estimates are statistically significant, the estimated Corrupt Government coefficient magnitude remains virtually unchanged. The fact that including these control variables has little effect on the FCR $\times$ Post 2004 coefficient suggests that differences in survey respondent characteristics across treatment and control areas are unlikely to explain our findings.

In Figure 3 Panel A, we plot the treatment effect over time for each Afrobarometer survey round. In support of the parallel-trends assumption, there is no visible difference in the pre-treatment trends in corruption perceptions for areas subject to foreign corruption regulation and those that are not. In the post-2004 period, the treatment effect is negative for all periods and particularly strong in the period immediately following the increase in FCPA enforcement (i.e., round R3 in $2005 / 2006)$. That the estimated treatment effect is largest in the period immediately after the enforcement increase and then subsequently declines is consistent with respondents benchmarking their perceptions against the "new normal" of a less corrupt environment over time. 
In Table 4 Panel B Columns (3) and (4), we examine changes in individuals' satisfaction with their local government. We find that, after the 2004 FCPA enforcement increase, residents of extraction areas subject to the regulation are approximately $18 \%$ more likely to be content with the performance of their local government. In Figure 3 Panel B, we map out the treatment effect over time and find no evidence of differing pre-period trends between the treatment and control groups. In the post-period, the treatment effect is positive for all periods and, once again, strongest immediately after the enforcement increase.

Overall, the analyses in this section suggest that a reduction in corruption is a potential explanation for the observed increase in economic activity around treated extraction areas following the post-2004 increase in FCPA enforcement.

\subsection{Contribution of Extraction Activity to Economic Growth}

Although we cannot directly measure changes in corrupt activities by firms in and connected to the extraction sector, if the increase in economic development following foreign corruption regulation is attributable to a reduction in corruption, we expect the activities of extraction firms to provide more benefits to the local community (e.g., by selecting the most economically efficient rather than the most politically connected supplier or contractor). To assess this possibility, we examine changes in the association between resource production and economic development around 2004 for facilities subject to the FCPA, relative to those that are not.

Examining changes in the association between resource production and economic development is complicated by two concerns. First, production decisions are endogenous. For instance, if the economic conditions in an area improve (e.g., because of business development unrelated to natural resources), resource extraction could become more profitable, and production quantities could increase. Second, because not all firms report facility-level production, data are limited.

To mitigate these concerns, we use variation in world commodity prices as an instrument for production quantities based on the idea that production should 
increase as the world commodity price increases (and vice versa). Fluctuations in world commodity prices are plausibly exogenous to the production decisions of individual facilities (i.e., individual extraction sites are too small to affect global commodity markets), and thus likely satisfy the exclusion restriction (below we provide evidence that the instrument also satisfies the relevance criterion). Using world prices as an instrument also has the advantage that it does not restrict our sample (Dube and Vargas 2013; Berman et al. 2017). ${ }^{12}$ We collect commodity prices from the US Geological Survey and the World Bank Commodities database and exclude coal and natural gas, for which there is no uniform global price.

These results, which condition the baseline association between foreign corruption regulation and economic activity on an exogenous shock to production, also alleviate the concern that a shock around 2005 (unrelated to the extraction sector) that differentially affects treated and non-treated cells could present an alternative explanation for our results. For instance, if the firms subject to foreign corruption regulation tend to operate in areas where their headquarter country has close economic connections (e.g., former colonies), any factor correlated with that economic connection that changes around 2005 (e.g., trade agreements, headquarter-country growth, or development aid) represents a potential correlated omitted variable. The narrower focus on how extraction activity maps into local economic development alleviates concerns about omitted variables that are uncorrelated with changes in world commodity prices. Table 2 reports descriptive statistics for the price instrument.

\subsubsection{Relevance of World Commodity Prices as an Instrument}

We assess the relevance of the price instrument by examining the association between commodity prices and resource production at the facility level

\footnotetext{
${ }^{12}$ A potential concern is that changes in commodity prices are highly correlated, limiting the variability of the instrument. However, as shown in Internet Appendix Section IA5.2, there is significant variation in world prices across commodities over time.
} 
(for the subset of facilities that report production quantities) using the following OLS regression:

$$
\text { Production } \left._{c, t}=\beta_{1} \text { Ln }_{\text {Price }}, t\right)+ \text { Fixed Effects }+\varepsilon_{c, t}
$$

Production is the production value (calculated using constant commodity prices from the year 2000) for the facility in cell $c$ and year $t$. Price is the average world price for commodity $m$ in year $t$. We include Property $\times$ Commodity and Year fixed effects and test for statistical significance using Conley (1999) standard errors corrected for spatial correlation within a $500-\mathrm{km}$ radius.

Table 5 Panel A Column (1) reports results. The Ln(Price) coefficient estimate is positive and statistically significant, indicating that facilities produce more when world commodity prices are higher. The coefficient magnitude, which can be interpreted as an elasticity, implies that a one percent increase in commodity prices is associated with a 0.807 percent increase in production. This elasticity decreases to 0.760 when we additionally control for region-specific time trends in Column (2). Overall, the results in Table 5 Panel A indicate that world commodity prices are a relevant instrument for extraction activities.

\subsubsection{Unconditional Association between Commodity Prices and Luminosity}

To provide a benchmark for how resource extraction affects economic activity, we examine the unconditional association between world commodity prices and luminosity. We use Eq. (3) but replace Production with Luminosity. Figure 4 graphs the $\beta_{1}$ coefficient estimates and $95 \%$ confidence intervals for cells with radii from 10 to 50 kilometers. The association between luminosity and commodity prices is positive for all radii and statistically significant for a radius of 10 kilometers when we include Property $\times$ Commodity and Year fixed effects, and for all reported radii when we replace Year with Region $\times$ Year fixed effects. At 10 kilometers, the $\beta_{1}$ coefficient estimate implies an elasticity of luminosity to world commodity prices of approximately 0.05 . Consistent with the increase in luminosity 
being attributable to the extraction facility, regardless of the fixed effect structure, the association between resource prices and luminosity monotonically declines in the radius of the cell. ${ }^{13}$

\subsubsection{Contribution of Resource Extraction to Development}

To examine how foreign corruption regulation affects the mapping of resource extraction into economic activity, we estimate the following regression:

$$
\begin{aligned}
\operatorname{Ln}\left(\text { Luminosity }_{c, t}\right)= & \beta_{1} F C R_{i} \times \text { Year }_{t} \times \operatorname{Ln}\left(\text { Price }_{m}\right) \\
& +\beta_{2} F C R_{i} \times \text { Year }_{t}+\text { Fixed Effects }+\varepsilon_{c, t}
\end{aligned}
$$

Similar to Eq. (1), we first estimate the treatment effect by year. As in Eq. (1), we include Property $\times$ Commodity and Commodity $\times$ Year fixed effects. In addition, we include $F C R \times$ Year fixed effects to control for time-trends in luminosity that differ between cells where facilities are subject to foreign corruption regulation and those that are not. We test for statistical significance using Conley (1999) standard errors corrected for spatial correlation within a $500-\mathrm{km}$ radius.

Figure 5 Panel A graphs the results from estimating Eq. (4). The estimated counterfactual treatment effects in the pre-treatment period are close to zero and statistically indistinguishable from the benchmark period. In the post-period, variation in resource production in treated cells, as captured by changes in world commodity prices, exhibits an increasing association with luminosity relative to control cells. The treatment effect stabilizes at an increase in the elasticity between luminosity and commodity prices of around 0.025 - an approximately $50 \%$ increase relative to the unconditional association between luminosity and commodity prices in a 10-kilometer radius, reported in Figure 4.

\footnotetext{
${ }^{13}$ Consistent with the evidence in Mamo et al. (2019), the positive association between resource extraction and luminosity also provides evidence against a strong form of the resource curse in Africa-although it does not preclude a less extreme version of the resource curse whereby the positive economic impact of resource extraction is less than what it would have been in the absence of corruption.
} 
In Table 5 Panel B, we report the magnitude of the average increase in extraction activities' contribution to economic growth over the entire post-2004 period and report several robustness tests. The baseline results reported in Column (1) suggest that, in the pre-period, the effect of extraction activities on economic growth is higher in areas with a facility subject to foreign corruption regulation relative to areas that are not, but the difference is not statistically significant (the $F C R \times \operatorname{Ln}($ Price) coefficient is 0.085$)$. More importantly, the estimated treatment effect of foreign corruption regulation, FCR $\times$ Post $2004 \times \operatorname{Ln}$ (Price), is 0.020 and statistically significant. The magnitude of the coefficient estimate implies a $40 \%$ increase relative to the unconditional association between luminosity and commodity prices in the 10-kilometer radius reported in Figure 4.

In Figure 5 Panel B, we graph the $F C R \times$ Post $2004 \times \operatorname{Ln}($ Price) coefficient estimates and their corresponding 95\% confidence intervals for cells with radii of 10 to 50 kilometers. We find that the impact of foreign corruption regulation on the association between production and luminosity decreases monotonically in the length of the radius around the extraction sites. The point estimates are positive for the radii up to 25 kilometers but statistically significant only within 10 kilometers of the extraction site.

In Table 5 Panel B Columns (2) to (5), we present the results of the same four sensitivity tests we report in Table 3. First, the estimated treatment effect increases to 0.026 in Column (2) when we transform our luminosity variable using the inverse hyperbolic sine. Second, we find results almost identical to the baseline model when we measure luminosity based on the donut-shaped 1-10 km area around the extraction site (coefficient of 0.019 compared to 0.020 in Column 1). Third, when we control for time-varying factors that are correlated with Africa's five regions in Column (4), the estimated treatment effect attenuates from 0.020 to 0.017 but remains statistically significant at the $10 \%$ level. Fourth, in Column (5), we find no evidence that a facility's being under US jurisdiction or being 
headquartered in an OECD country is associated with a treatment effect absent an increase in FCPA enforcement.

Overall, consistent with firms and local officials in and around the extraction sector altering their business practices after the post-2004 increase in FCPA enforcement, the evidence in this section suggests that extraction firms' contribution to local economic activity is higher in the presence of foreign corruption regulation.

\subsection{New Firms Entering the Extraction Sector}

Our findings that perceived corruption decreases and economic growth increases after foreign corruption regulation could be explained by extraction facilities being acquired by firms that do not pay bribes (perhaps because they are more productive than bribe-paying firms). In this section, we examine whether changes in ownership can explain the increase in extraction firms' contribution to local economic development.

To assess whether new owners drive the observed increase in economic activity, in Internet Appendix Section IA6, we examine changes in luminosity around mine ownership changes in the post-2004 period. These results indicate that, among extraction sites that change owners, the increase in growth mainly occurs before the ownership change. This suggests that the increase in economic activity is more likely attributable to changes in how existing owners operate extraction sites than new (non-bribe paying firms) entering the market. ${ }^{14}$

\footnotetext{
${ }^{14}$ This finding raises the question of how firms can continue to operate without paying bribes. One possibility is that firms appease local officials by engaging in business practices that are more beneficial to the local communities where they operate (but that were more expensive than paying a bribe prior to the increase in FCPA enforcement). In Internet Appendix Section IA7, we report some of the activities firms report engaging in that could potentially benefit the local communities where they operate. Based on micro survey data from 2010 (Boly et al. 2015), we show (crosssectionally) that OECD firms operating in Africa report that they are more likely than non-OECD firms to hire local suppliers, train local employees, and pay their employees more.
} 


\section{Conclusion}

Recognizing the negative economic impact of corruption in developing countries, governments in many developed countries have enacted regulations to curb the bribery of foreign public officials. The most prominent and widely enforced of these foreign corruption regulations is the US FCPA. We examine the impact of a significant increase in FCPA enforcement on economic development in the corruption-prone African extraction sector. Measuring local economic activity by nighttime luminosity, we document that, after the increase in FCPA enforcement, economic activity increases by $14 \%$ within a radius of 10 kilometers of extraction facilities whose owners are subject to the FCPA. This increase in economic development is concentrated in areas with weak political institutions, where we expect that the resource curse is most prevalent. Consistent with a decline in corruption contributing to the increase in economic activity, local perceptions of corruption decline, and peoples' satisfaction with the local government increases. We find no evidence of a decline in employment in the extraction sector. Rather, consistent with the increase in economic activity being driven (at least in part) by extraction firms shifting to business practices that are more beneficial (or less detrimental) to the local communities where they operate, the association between extraction activities and local economic activity increases by $40 \%$.

Our findings suggest that foreign corruption regulation can be an effective policy instrument for changing corporate behavior and that, despite any increase in the costs of operating in high-corruption-risk countries, foreign corruption regulation originating in developed countries can have a positive impact on the economic conditions in developing countries - that is, it can (to some extent) mitigate factors that contribute to the political resource curse. This is important because developing countries may not themselves have the institutional strength or political will to address misconduct by multinational corporations. 


\section{References}

Acemoglu, D., and Robinson, J. A. (2012). Why Nations Fail: The Origins of Power, Prosperity and Poverty. New York: Crown Publishers.

Aragón, F.M., and Rud, J.P. (2013). "Natural Resources and Local Communities: Evidence from a Peruvian Gold Mine." American Economic Journal: Economic Policy, 5 (2): 1-25.

Aragón, F.M., and Rud, J.P. (2016). "Polluting Industries and Agricultural Productivity: Evidence from Mining in Ghana." Economic Journal, 126: 1980-2011.

Armand, A., Coutts, A., Vicente, P. C., and Vilela, I. (2020). "Does Information Break the Political Resource Curse? Experimental Evidence from Mozambique.” American Economic Review, 110(11): 3431-53.

Auty, R.M. (1993). Sustaining Development in Mineral Economies: The Resource Curse Thesis. New York: Routledge.

Avis, E., Ferraz, C., and Finan, F. (2018). "Do Government Audits Reduce Corruption? Estimating the Impacts of Exposing Corrupt Politicians." Journal of Political Economy, 126: 1912-1964.

Bauer, P., and Beard, V.P. (2004). "Data Codebook for the Twelve-Country Merged Data Set compiled from Round 1 Afrobarometer Surveys in Botswana, Ghana, Lesotho, Malawi, Mali, Namibia, Nigeria, South Africa, Tanzania, Uganda, Zambia and Zimbabwe." Afrobarometer

Beck, P. J., Maher, M. W., and Tschoegl, A. E. (1991). "The Impact of the Foreign Corrupt Practices Act on US Exports." Managerial \& Decision Economics, 12(4), 295-303.

BenYishay, A., Rotberg, R., Wells, J., Lv, Z., Goodman, S., Kovacevic, L., and Runfola, D. (2017). Geocoding Afrobarometer Rounds 1-6: Methodology \& Data Quality. AidData.

Berman, N., Couttenier, M., Rohner, D., and Thoenig, M. (2017). "This Mine is Mine! How Minerals Fuel Conflicts in Africa." American Economic Review, 107(6), 1564-1610.

Bertrand, M., Bombardini, M., Fisman, R., and Trebbi, F. (2020). "Tax-Exempt Lobbying: Corporate Philanthropy as a Tool for Political Influence." American Economic Review, 110 (7): 2065-2102.

Blundell-Wignall, A., and Roulet, C. (2017). "Foreign Direct Investment, Corruption and the OECD Anti-Bribery Convention." OECD Working Papers on International Investment, 2017/01. Paris: OECD Publishing.

Bobonis, G. J., Camara Fuertes, L. R., and Schwabe, R. (2016). "Monitoring Corruptible Politicians." American Economic Review, 106(8), 2371-2405.

Boly, A., Coniglio, N. D., Prota, F., and Seric, A. (2015). "Which Domestic Firms Benefit from FDI? Evidence from Selected African Countries". Development Policy Review, 33(5), 615-636.

Brewster, R., and Buell, S. W. (2017). "The Market for Global Anticorruption Enforcement." Law and Contemporary Problems, 80(1), 193-214.

Christensen, H., Maffett, M., and Rauter, T. (2020). "Policeman for the World: The Impact of Extraterritorial FCPA Enforcement on Foreign Investment and Internal Controls." Working Paper.

Chuhan-Pole, P., Dabalen, A., and Land, B. (2017). Mining in Africa. Are Local Communities Better Off? Washington, DC: World Bank.

Colonnelli, E., and Prem, M. (2020). "Corruption and Firms." Working Paper.

Conley, T.G. (1999). "GMM Estimation with Cross Sectional Dependence." Journal of Econometrics 92 (1): 1-45.

Corden, W., and Neary, J. (1982). "Booming Sector and De-Industrialisation in a Small Open Economy." The Economic Journal, 92(368), 825-848.

Croson, R., and Gneezy, U. (2009). "Gender Differences in Preferences." Journal of Economic Literature, 47 (2): 448-74.

Cuervo-Cazurra, A. (2006). "Who Cares about Corruption?" Journal of International Business Studies 37(6): 803-822. 
Cuervo-Cazurra, A. (2008). "The Effectiveness of Laws against Bribery Abroad." Journal of International Business Studies, 39(4), 634-651.

D'Acunto, F. (2020). "Identity and Choice Under Risk." Working Paper.

D'Souza, A. (2012). "The OECD Anti-Bribery Convention: Changing the Currents of Trade." Journal of Development Economics 97: 73-87.

Deaton, A. (1999). "Commodity Prices and Growth in Africa." Journal of Economic Perspectives, 13 (3): 23-40.

Dube, O., and Vargas, J. F. (2013). "Commodity Price Shocks and Civil Conflict: Evidence from Colombia." Review of Economic Studies, 80(4), 1384-1421.

Dutt, P., and Traca, D. (2010). "Corruption and Bilateral Trade Flows: Extortion or Evasion." Review of Economics and Statistics, 92(4): 843-860.

Ferraz, C., and Finan, F. (2008). "Exposing Corrupt Politicians: The Effects of Brazil's Publicly Released Audits on Electoral Outcomes." Quarterly Journal of Economics, 123(2), 703-745.

Graham, J. L. (1984). "The Foreign Corrupt Practice Act: A New Perspective." Journal of International Business Studies, 15(3), 107-121.

Guidolin, M., and Ferrara, E. L. (2007). "Diamonds Are Forever, Wars Are Not: Is Conflict Bad for Private Firms?" American Economic Review, 97 (5): 1978-1993.

Guiso, L., Sapienza, P., and Zingales, L. (2009). "Cultural Biases in Economic Exchange." Quarterly Journal of Economics, 1095-1131.

Henderson, J.V., Storeygard, A., and Weil, D.N. (2011). "A Bright Idea for Measuring Economic Growth.” American Economic Review: Papers \& Proceedings 2011, 101:3, 194-199.

Henderson, J.V., Storeygard, A., and Weil, D.N. (2012). "Measuring Economic Growth from Outer Space." American Economic Review, 102 (2), 994-1028.

Hines, J. Jr. (1995). "Forbidden Payment: Foreign Bribery and American Business after 1977." National Bureau of Economic Research. Working Paper.

Hodler, R., and Raschky, P. (2014). "Regional Favouritism." Quarterly Journal of Economics, 129(2), 995-1033.

Hsieh, C., and Klenow, P. (2009). "Misallocation and Manufacturing TFP in China and India." Quarterly Journal of Economics, 124(4), 1403-1448.

Humphreys, M., Sachs, J., and Stiglitz, J. E. (2007). Escaping the Resource Curse. New York: Columbia University Press.

Hunt, J. (2004). "Trust and Bribery: The Role of the Quid Pro Quo and the Link with Crime.” NBER Working Paper, No. 10510.

Huskins, P. C. (2008). "FCPA Prosecutions: Liability Trend to Watch.” Stanford Law Review, 60(5), 1447-1457.

Johnson, S., Larson, W., Papageorgiou, C., and Subramanian, A. (2009). "Is Newer Better? Penn World Table Revisions and Their Impact on Growth Estimates." National Bureau of Economic Research Working Paper 1545.

Karpoff, J., Lee, D. S., and Martin, G. S. (2017). "Foreign Bribery: Incentives and Enforcement." Working Paper.

Mamo, N., Bhattacharyya, S., and Moradi, A. (2019). "Intensive and Extensive Margins of Mining and Development: Evidence from Sub-Saharan Africa." Journal of Development Economics 139: $28-49$

Martin, G., Karpoff, J., Lee, D., and Cooper, J. (2012). “The Foreign Corrupt Practices Act: An Empirical Examination of Enforcement Trends." Working paper.

Mauro, P. (1995). “Corruption and Growth.” Quarterly Journal of Economics, 110(3): 681-712.

Mehlum, H., Moene, K., and Torvik, R. (2006). "Institutions and the Resource Curse." Economic Journal, 116: 1-20. 
Melgar, N., Rossi, M., and Smith, T.W. (2010). "The Perception of Corruption." International Journal of Public Opinion Research, 22 (1): 120-131.

Michalopoulos, S., and Papaioannou, E. (2013). "Pre-Colonial Ethnic Institutions and Contemporary African Development." Econometrica, 81: 113-152.

Michalopoulos, S., and Papaioannou, E. (2014). "National Institutions and Subnational Development in Africa." Quarterly Journal of Economics, 129(1), 151-213.

Mocan, N. (2004). "What Determines Corruption? International Evidence from Micro Data." NBER Working Paper, No. 10460.

OECD. (2014). Foreign Bribery Report: An Analysis of the Crime of Bribery of Foreign Public Officials. Paris: OECD Publishing.

OECD. (2016). Corruption in the Extractive Value Chain - Typology of Risks, Mitigation Measures and Incentives. OECD.

OECD. (2019). 2018 Enforcement of the Anti-Bribery Convention - Investigations, proceedings, and sanctions. OECD Working Group on Bribery, December 2019

Olken, B. A. (2007). "Monitoring Corruption: Evidence from a Field Experiment in Indonesia." Journal of Political Economy 115(2), 200-249.

Olken, B. A., and Pande, R. (2012). "Corruption in Developing Countries." Annual Review of Economics, 4(1), 479-509.

Ortiz-Ospina, E., and Roser, M. (2016). "Corruption." Our World in Data. Retrieved from: https://ourworldindata.org/corruption.

Ramey, G., and Ramey, V. (1995). "Cross-Country Evidence on the Link between Volatility and Growth." American Economic Review, 85(5), 1138-1151.

Rauter, T. (2020). "The Impact of Mandatory Extraction Payment Disclosures on Corporate Payment and Investment Policies Abroad." Journal of Accounting Research. Forthcoming.

Robinson, J. A., Torvik, R., and Verdier, T. (2006). "Political Foundations of the Resource Curse." Journal of Development Economics, 79(2), 447-468.

Sachs, J., and Warner, A. (1995). "Natural Resource Abundance and Economic Growth." NBER Working Paper, No 5398.

Sanseverino, A. (2020). "The Impact of Anti-Corruption Laws: Evidence from the U.K. Bribery Act's Extraterritorial Reach." Working Paper.

Sarr, M., Bulte, E., Meissner, C., and Swanson, T. (2011). "On the Looting of Nations." Public Choice, 148: 353-380.

Smith, B. (2015). "The Resource Curse Exorcised: Evidence from a Panel of Countries." Journal of Development Economics, 116, 57-73.

Shleifer, A., and Vishny, R.W. (1993). "Corruption.” Quarterly Journal of Economics 108(3), 599617.

Torgler, B., and Valev, N.T. (2006). "Corruption and Age." Journal of Bioeconomics 8:133-145

UNCTAD. (2012). "Extractive industries: Optimizing Value Retention in Host Countries." UNCTAD/SUC. New York and Geneva, United Nations

US Department of Justice and US Securities and Exchange Commission. (2012). A Resource Guide to the US Foreign Corrupt Practices Act. Washington D.C.: US. Department of Justice. Retrieved from: https://www.justice.gov/criminal-fraud/fcpa-guidance.

US Securities and Exchange Commission. (2017). In the Matter of Halliburton Company. Release No. 81222. Retrieved from: https://www.sec.gov/litigation/admin/2017/34-81222.pdf

Zamboni, Y., and Litschig, S. (2018). "Audit Risk and Rent Extraction: Evidence from a Randomized Evaluation in Brazil." Journal of Development Economics, (134), 133-149.

Zeume, S. (2017). "Bribes and Firm Value." Review of Financial Studies, 30(5), 1457-1489. 
Figure 1: Geographical Distribution of Extraction Facilities and Commodities

Panel A: Treated and Control Extraction Facilities

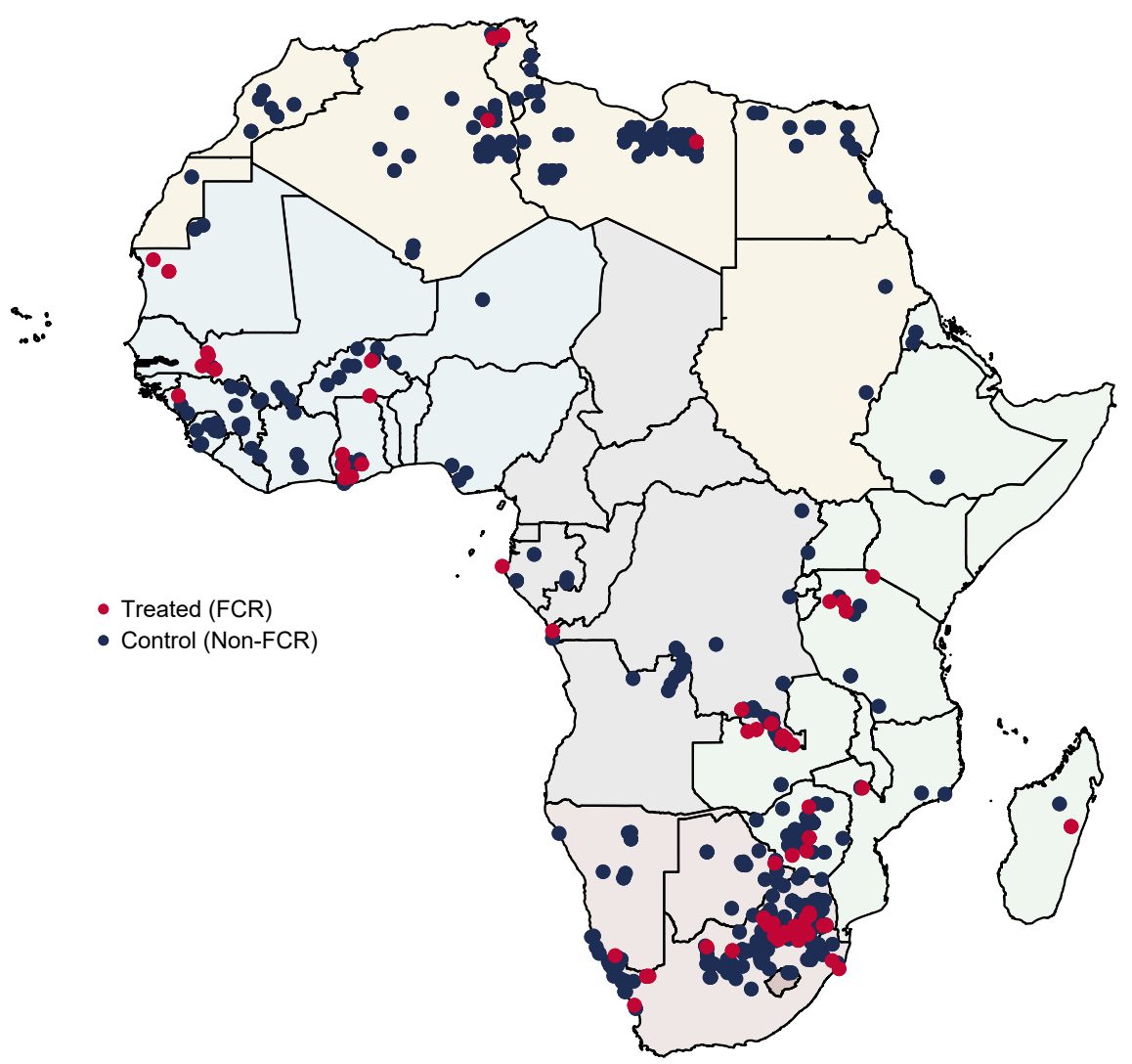

Panel B: Extraction Facilities by Commodity

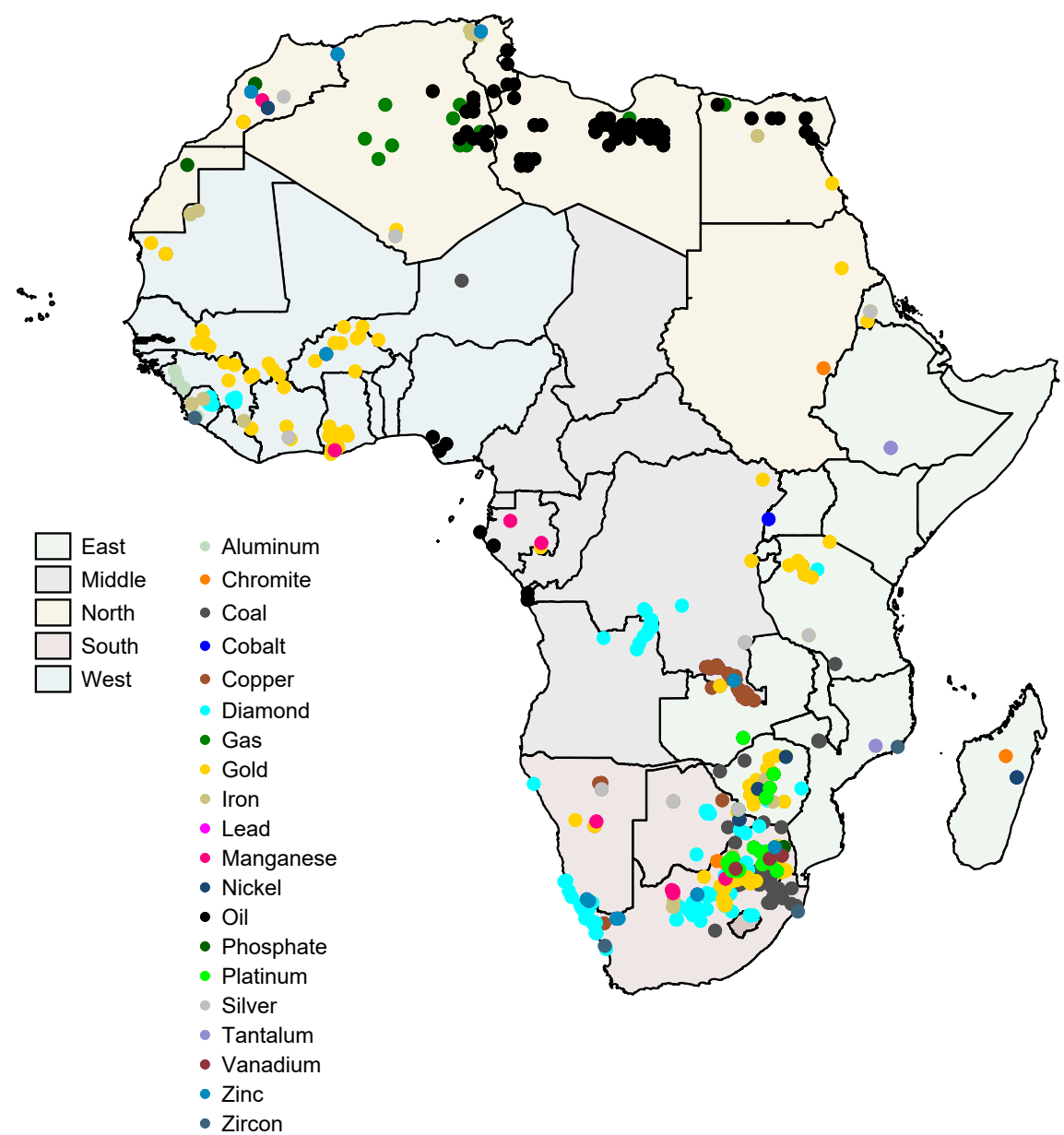

Notes: Panel A shows the geographical location of treated and control facilities in our sample. Treated extraction facilities have at least one significant owner (with an ownership stake of $20 \%$ or more) in 2004 who is headquartered, cross-listed, or operates a segment in the US and is from a signatory country of the OECD Anti-Bribery Convention. All other extraction facilities belong to the control group. Panel B shows the geographical location of extraction facilities in our sample by commodity. Both figures also show the five main geographic regions of Africa. 


\section{Figure 2: Foreign Corruption Regulation and Economic Activity in Extraction Areas}

Panel A: Event-time Chart

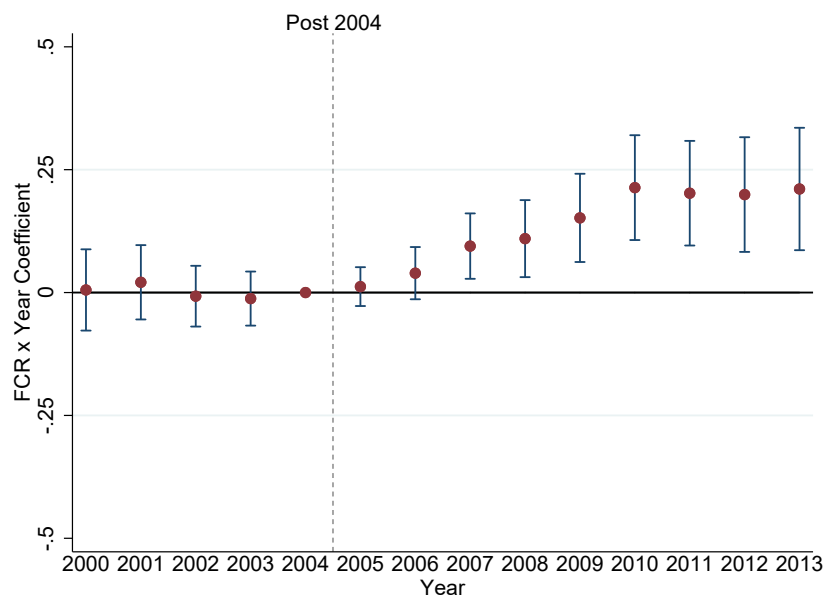

Panel B: Spatial Diffusion of Luminosity Effect

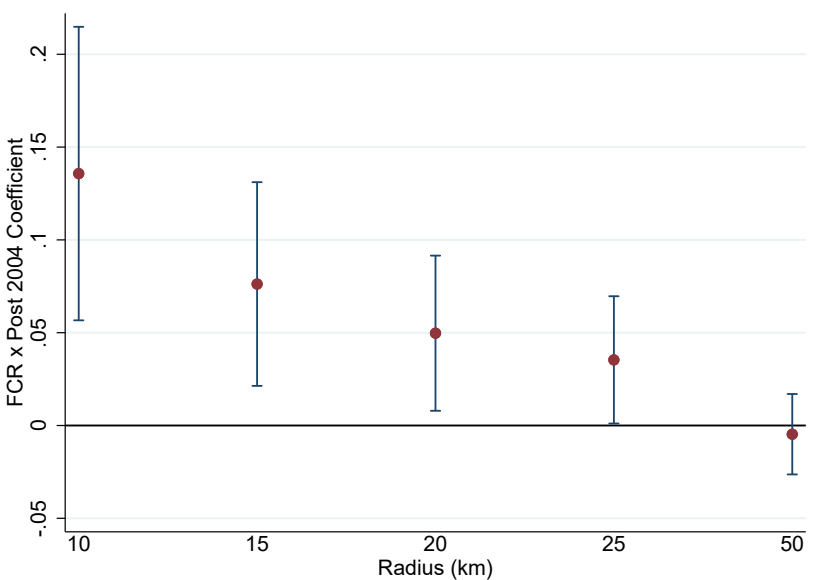

Panel C: The Role of Political Institutions

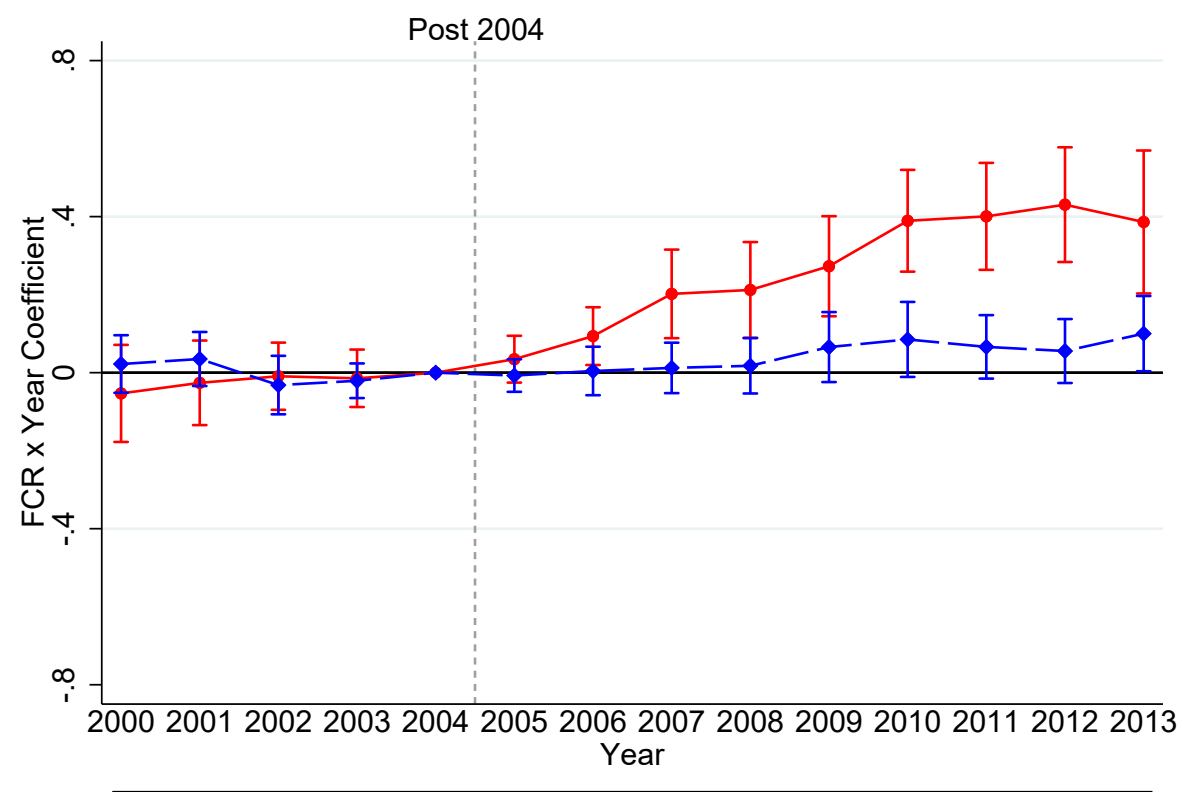

$\longrightarrow$ Weak Political Institution Countries —ઐ - Strong Political Institution Countries

Notes: Panel A shows coefficient estimates and 95\% confidence intervals for OLS regressions estimating the effect of the post-2004 increase in FCPA enforcement on nighttime luminosity. We estimate the model from Column (1) of Table 3 but replace the $F C R \times$ Post 2004 indicator with separate interactions for each of the years in our sample (except for 2004, which serves as the benchmark). Panel B shows coefficient estimates of FCR $\times$ Post 2004 and $95 \%$ confidence intervals for cell areas with radii of $10 \mathrm{~km}, 15 \mathrm{~km}, 20 \mathrm{~km}, 25 \mathrm{~km}$, and $50 \mathrm{~km}$, respectively. We estimate the model from Column (1) of Table 3 but use different cell areas. Panel $\mathrm{C}$ shows coefficient estimates and 95\% confidence intervals for OLS regressions estimating the effect of the post-2004 increase in FCPA enforcement on nighttime luminosity for weak and strong political institution countries, respectively. We estimate the model from Columns (6) and (7) of Table 3 but replace the FCR $\times$ Post 2004 indicator with separate interactions for each of the years in our sample (except for 2004, which serves as the benchmark). 


\section{Figure 3: Foreign Corruption Regulation, Perceptions of Corruption, and Satisfaction with Local Officials}

Panel A: Corrupt Government

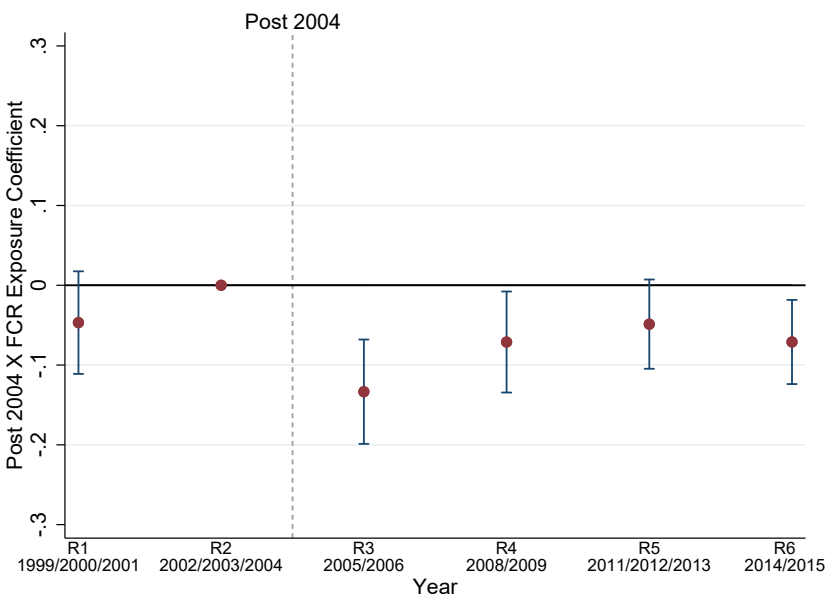

Panel B: Satisfied with Local Government

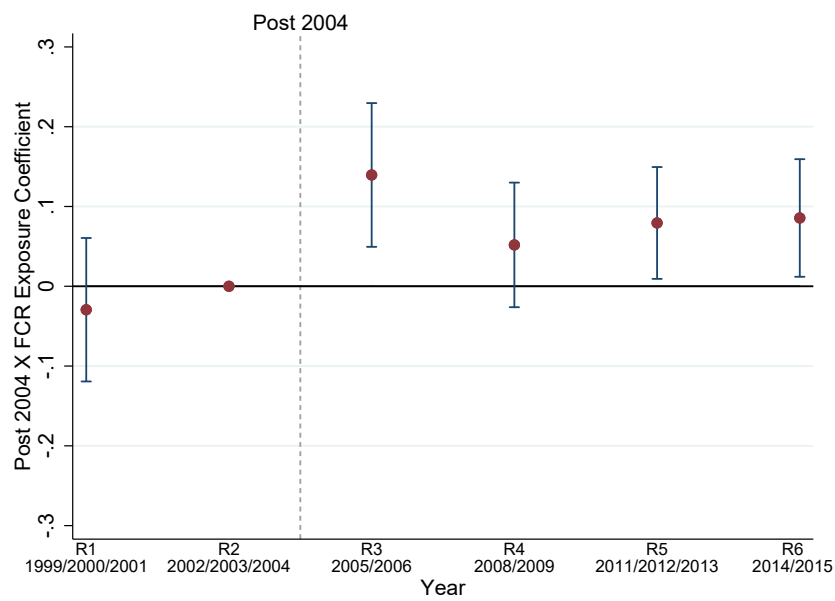

Notes: Panel A shows coefficient estimates and 95\% confidence intervals for OLS regressions estimating the effect of the post-2004 increase in FCPA enforcement on the perceived corruption of government officials. We estimate the model from Column (1) of Table 4 Panel B but replace the FCR Exposure $\times$ Post 2004 indicator with separate interactions for each survey round in our sample (except for round 2, which serves as the benchmark). Panel B shows coefficient estimates and 95\% confidence intervals for OLS regressions estimating the effect of the post-2004 increase in FCPA enforcement on the perceived satisfaction with local governments. We estimate the model from Column (3) of Table 4 Panel B but replace the FCR Exposure $\times$ Post 2004 indicator with separate interactions for each survey round in our sample (except for round 2, which serves as the benchmark).

\section{Figure 4: Unconditional Association between Commodity Prices and Luminosity}

Panel A: With Property $\times$ Commodity and Year Fixed Effects

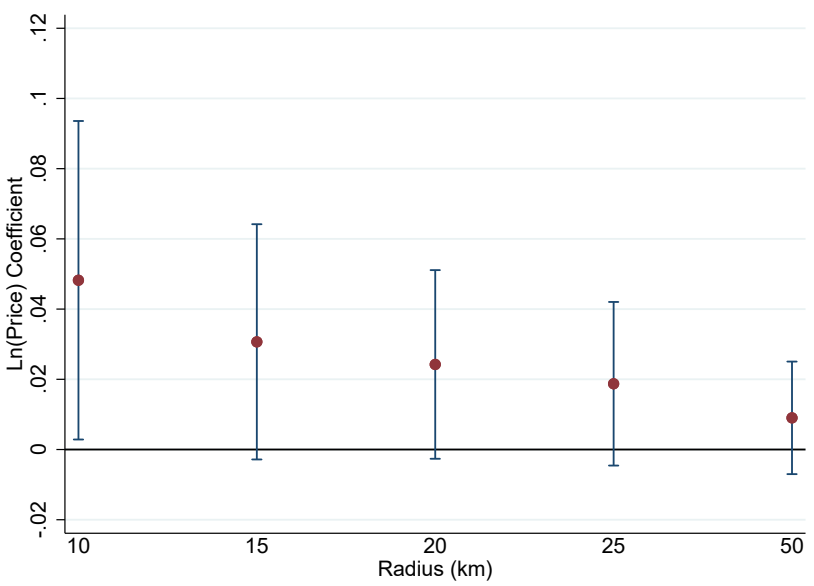

Panel B: With Property $\times$ Commodity and Region $\times$ Year Fixed Effects

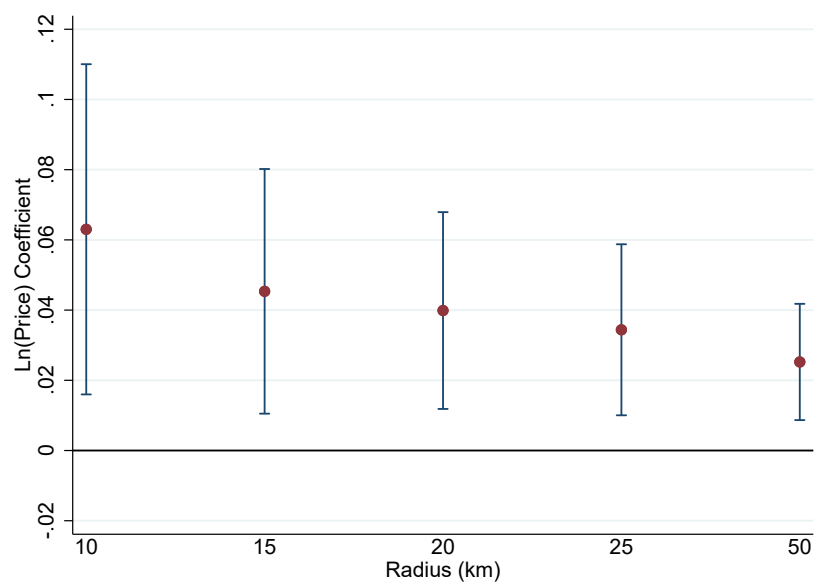

Notes: This figure shows the coefficient estimates and 95\% confidence intervals of OLS regressions estimating the association between world commodity prices and nighttime luminosity for cell areas with radii of $10 \mathrm{~km}, 15 \mathrm{~km}, 20 \mathrm{~km}, 25 \mathrm{~km}$, and $50 \mathrm{~km}$, respectively. 


\title{
Figure 5: Foreign Corruption Regulation and the Contribution of Resource Extraction to Development
}

\author{
Panel A: Event-time Chart
}

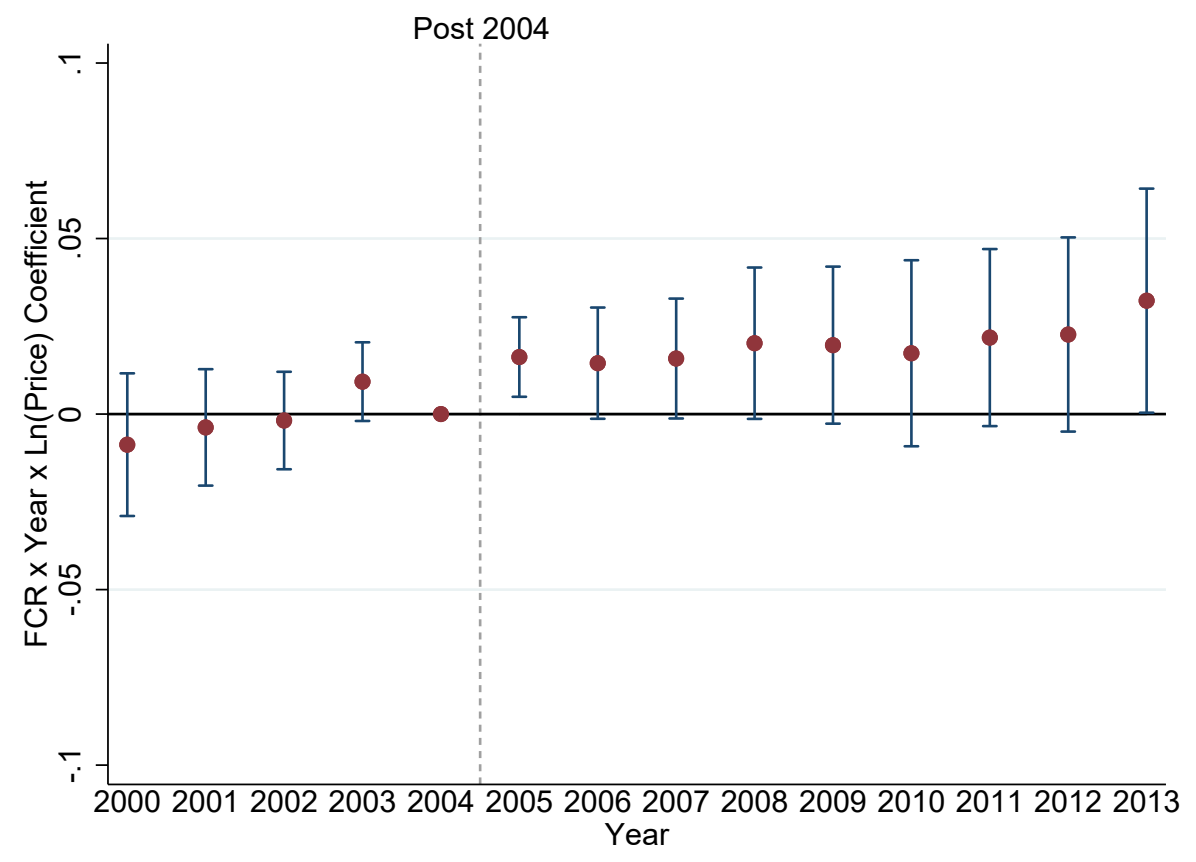

Notes: Panel A shows coefficient estimates and 95\% confidence intervals for OLS regressions estimating the effect of the post-2004 increase in FCPA enforcement on the association between world commodity prices and nighttime luminosity. We estimate the model from Column (1) of Table 5 Panel B but replace the FCR $\times$ Post $2004 \times$ Ln (Price) indicator with separate interactions for each of the years in our sample (except for 2004, which serves as the benchmark).

Panel B: Spatial Diffusion of Luminosity Effect

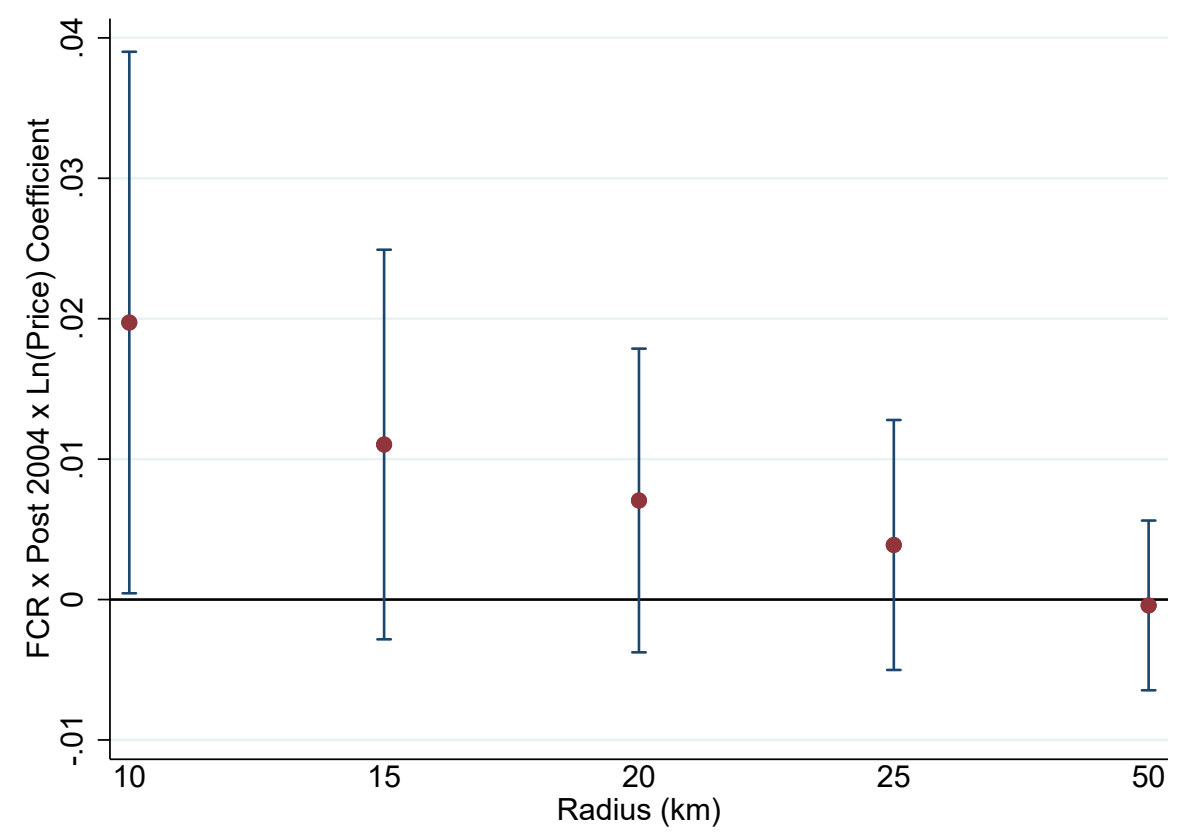

Notes: Panel B shows coefficient estimates of FCR $\times$ Post $2004 \times$ Ln(Price) and $95 \%$ confidence intervals for cell areas with radii of $10 \mathrm{~km}, 15 \mathrm{~km}, 20 \mathrm{~km}, 25 \mathrm{~km}$, and $50 \mathrm{~km}$, respectively. We estimate the model from Column (1) of Table 5 Panel B but use different cell areas for our dependent variable Ln(Luminosity +1$)$. 


\section{Table 1: Characteristics of Extraction Areas}

\section{Panel A: Perceived Corruption of Foreign Businessmen}

\begin{tabular}{lccc}
\hline \hline & $\begin{array}{c}\text { Number of } \\
\text { Respondents }\end{array}$ & $\begin{array}{c}\text { Perceived Corruption of } \\
\text { Foreign Businessmen }\end{array}$ & $\begin{array}{c}\text { Difference Extraction vs. } \\
\text { Non-Extraction Areas } \\
\text { (p-value) }\end{array}$ \\
\hline Extraction Areas (0-50km) & 15,165 & 0.0714 & $0.0711(0.000)$ \\
Non-Extraction Areas & 15,190 & 0.0004 & \\
\hline
\end{tabular}

Notes: This table presents descriptive statistics for corruption perceptions of foreign businessmen in extraction and non-extraction areas. P-values of the mean comparison t-tests are reported in parentheses. We de-mean Perceived Corruption of Foreign Businessmen before computing averages for extraction areas and non-extraction areas. A survey location is in an extraction area if the distance between the survey location and the closest extraction property is less than or equal to $50 \mathrm{~km}$. A survey location is in a non-extraction area if the distance between the survey location and the closest extraction property is more than $50 \mathrm{~km}$. Perceived Corruption of Foreign Businessmen is the average response value for the Afrobarometer survey question: How many of the following people do you think are involved in corruption, or haven't you heard enough about them to say: Foreign businessmen? $0=$ None, $1=$ Some of them, $2=$ Most of them, $3=$ All of them.

\section{Panel B: Employment in Mining Sector}

\begin{tabular}{cccc}
\hline \hline & & & Number of \\
Respondents & $\begin{array}{c}\text { Fraction of } \\
\text { Mine Workers }\end{array}$ & $\begin{array}{c}\text { Difference Mining vs. } \\
\text { Non-Mining Areas } \\
\text { (p-value) }\end{array}$ \\
\hline Mining Areas: & 1,407 & 0.182 & $0.173(0.000)$ \\
$0-10 \mathrm{~km}$ & 2,369 & 0.179 & $0.170(0.000)$ \\
$0-15 \mathrm{~km}$ & 3,709 & 0.166 & $0.157(0.000)$ \\
$0-20 \mathrm{~km}$ & 5,115 & 0.154 & $0.145(0.000)$ \\
$0-25 \mathrm{~km}$ & 15,874 & 0.097 & $0.088(0.000)$ \\
$0-50 \mathrm{~km}$ & 18,044 & 0.009 & \\
\hline
\end{tabular}

Notes: This table presents descriptive statistics for mining-related employment in mining and non-mining areas. P-values of the mean comparison t-tests are reported in parentheses. A survey location is in a mining area if the distance between the survey location and the closest mine is less than or equal to $10 \mathrm{~km}, 15 \mathrm{~km}$, $20 \mathrm{~km}, 25 \mathrm{~km}$, and $50 \mathrm{~km}$, respectively. A survey location is in a non-mining area if the distance between the survey location and the closest mine is more than $50 \mathrm{~km}$. Fraction of Mine Workers is the fraction of workers that indicated their main occupation as Miner based on the Afrobarometer survey question: What is your main occupation? (If unemployed, retired, or disabled, what was your last main occupation?). 


\section{Table 2: Descriptive Statistics for Luminosity Analyses}

\begin{tabular}{|c|c|c|c|c|c|c|c|c|}
\hline & $\mathrm{N}$ & Mean & $\mathrm{SD}$ & $\mathrm{P} 1$ & P25 & P50 & P75 & P99 \\
\hline Luminosity (10) & 10,318 & 7.662 & 10.399 & 0.000 & 0.476 & 3.046 & 10.317 & 44.141 \\
\hline Luminosity (1-10) & 10,318 & 7.596 & 10.369 & 0.000 & 0.449 & 2.964 & 10.158 & 44.151 \\
\hline Luminosity (15) & 10,318 & 6.190 & 8.566 & 0.000 & 0.439 & 2.336 & 8.843 & 37.104 \\
\hline Luminosity (20) & 10,318 & 5.361 & 7.329 & 0.000 & 0.393 & 2.071 & 7.750 & 32.284 \\
\hline Luminosity (25) & 10,318 & 4.786 & 6.396 & 0.000 & 0.396 & 2.045 & 7.099 & 28.341 \\
\hline Luminosity (50) & 10,318 & 3.544 & 4.619 & 0.000 & 0.308 & 1.651 & 4.824 & 20.418 \\
\hline$F C R$ & 10,318 & 0.155 & 0.362 & 0.000 & 0.000 & 0.000 & 0.000 & 1.000 \\
\hline USJ Non-OECD & 10,318 & 0.199 & 0.400 & 0.000 & 0.000 & 0.000 & 0.000 & 1.000 \\
\hline Non-USJ OECD & 10,318 & 0.141 & 0.348 & 0.000 & 0.000 & 0.000 & 0.000 & 1.000 \\
\hline Post 2004 & 10,318 & 0.643 & 0.479 & 0.000 & 0.000 & 1.000 & 1.000 & 1.000 \\
\hline Price & 8,694 & $6,430.251$ & $10,334.401$ & 0.024 & 1.450 & 51.800 & $10,400.000$ & $38,200.000$ \\
\hline
\end{tabular}

Notes: This table presents descriptive statistics for the luminosity analyses in Table 3 and Table 5 Panel B We describe the sample selection in Internet Appendix Section IA2. The sample is from 2000 to 2013. Luminosity (X) is the stable light mean unsaturated nighttime luminosity within an $\mathrm{X} \mathrm{km}$ radius of the respective property, where we consider $\mathrm{X}$ values of $10,1-10,15,20,25$, and 50 . FCR is a binary indicator equal to one if an extraction facility has at least one significant owner (with an ownership stake of $20 \%$ or more) in 2004 who is headquartered, cross-listed, or operates a segment in the US and is from a signatory country of the OECD Anti-Bribery Convention. USJ Non-OECD is a binary indicator equal to one if a property has at least one significant owner (with an ownership stake of $20 \%$ or more) in 2004 who is cross-listed or operates a segment in the US but is not from a signatory country of the OECD Anti-Bribery Convention. Non-USJ OECD is a binary indicator equal to one if a property has at least one significant owner (with an ownership stake of $20 \%$ or more) in 2004 who is from a signatory country of the OECD Anti-Bribery Convention but is not cross-listed and does not operate a segment in the US. Post 2004 is a binary indicator equal to one for years after 2004. Price (in USD) is the world price of a given commodity in a given year.

\section{Table 3: Foreign Corruption Regulation and Economic Activity in Extraction Areas}

\begin{tabular}{|c|c|c|c|c|c|c|c|}
\hline \multirow[b]{3}{*}{$\begin{array}{l}\text { Dependent Variable: } \\
\text { Ln(Luminosity }(10)+1)\end{array}$} & \multirow{3}{*}{$\begin{array}{l}\frac{\text { Baseline }}{(1)} \\
\text { 0-10 km } \\
\text { Radius }\end{array}$} & \multicolumn{4}{|c|}{ Sensitivity Analyses } & \multicolumn{2}{|c|}{ Role of Institutions } \\
\hline & & $(2)$ & (3) & $(4)$ & (5) & $\begin{array}{c}(6) \\
\text { Weak }\end{array}$ & $\begin{array}{c}(7) \\
\text { Strong }\end{array}$ \\
\hline & & $\begin{array}{c}\text { Asinh } \\
\text { (Luminosity) }\end{array}$ & $\begin{array}{l}1-10 \mathrm{~km} \\
\text { Radius }\end{array}$ & $\begin{array}{c}\text { Within } \\
\text { Region } \times \text { Year }\end{array}$ & $\begin{array}{l}\text { USJ Non-OECD } \\
\text { and Non-USJ OECD }\end{array}$ & $\begin{array}{l}\text { Political } \\
\text { Institutions }\end{array}$ & $\begin{array}{l}\text { Political } \\
\text { Institutions }\end{array}$ \\
\hline FCR $\times$ Post 2004 & $\begin{array}{c}0.136 \\
(0.040)\end{array}$ & $\begin{array}{c}0.184 \\
(0.052)\end{array}$ & $\begin{array}{c}0.130 \\
(0.039)\end{array}$ & $\begin{array}{c}0.141 \\
(0.039)\end{array}$ & $\begin{array}{c}0.134 \\
(0.041)\end{array}$ & $\begin{array}{l}0.290 \\
(0.074)\end{array}$ & $\begin{array}{c}0.043 \\
(0.043)\end{array}$ \\
\hline USJ Non-OECD $\times$ Post 2004 & & & & & $\begin{array}{l}-0.030 \\
(0.040)\end{array}$ & & \\
\hline Non-USJ OECD $\times$ Post 2004 & & & & & $\begin{array}{c}0.043 \\
(0.039)\end{array}$ & & \\
\hline \multicolumn{8}{|l|}{ Difference in Coefficients (p-value): } \\
\hline $\begin{array}{l}{[\text { FCR-USJ Non-OECD }] \times \text { Post } 2004} \\
{[\text { FCR-Non-USJ OECD }] \times \text { Post } 2004} \\
\text { Weak-Strons Political Institutions }\end{array}$ & & & & & $\begin{array}{l}0.00 \\
0.08\end{array}$ & & \\
\hline $\begin{array}{l}\text { Weak-Strong Political Institutions } \\
\text { Fixed Effects: }\end{array}$ & & & & & & & \\
\hline Property $\times$ Commodity & Yes & Yes & Yes & Yes & Yes & Yes & Yes \\
\hline Region $\times$ Year & No & No & No & Yes & No & No & No \\
\hline Commodity $\times$ Year & Yes & Yes & Yes & Yes & Yes & Yes & Yes \\
\hline Property-Commodity-Year Observations & 10,318 & 10,318 & 10,318 & 10,318 & 10,318 & 3,836 & 5,824 \\
\hline
\end{tabular}

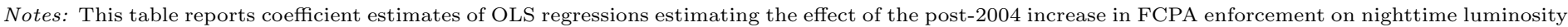

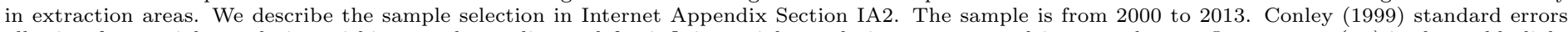

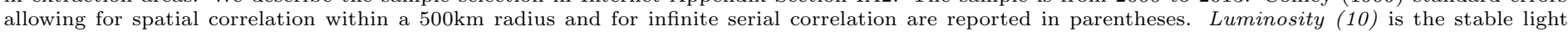

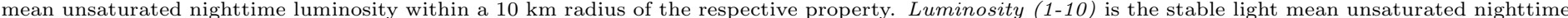

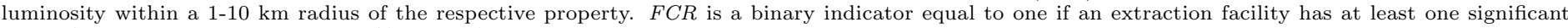

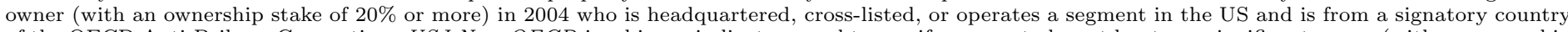

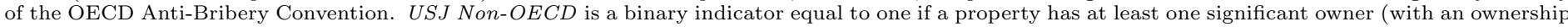

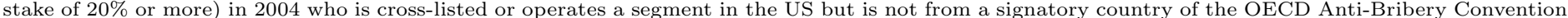

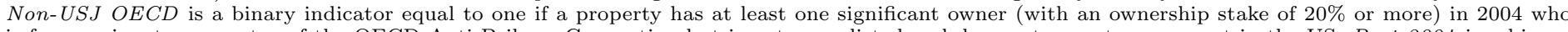

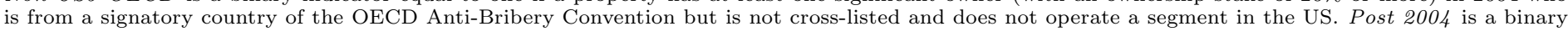
indicator equal to one for years after 2004 
Table 4: Effect of Foreign Corruption Regulation on Perceptions of
Corruption and Satisfaction with Local Officials

\section{Panel A: Descriptive Statistics}

\begin{tabular}{|c|c|c|c|c|c|c|c|c|}
\hline & $\mathrm{N}$ & Mean & $\mathrm{SD}$ & P1 & P25 & P50 & P75 & P99 \\
\hline FCR Exposure & 56,276 & 0.176 & 0.381 & 0.000 & 0.000 & 0.000 & 0.000 & 1.000 \\
\hline Corrupt Government & 56,276 & 0.444 & 0.497 & 0.000 & 0.000 & 0.000 & 1.000 & 1.000 \\
\hline Post 2004 & 56,276 & 0.767 & 0.423 & 0.000 & 1.000 & 1.000 & 1.000 & 1.000 \\
\hline Female & 56,276 & 0.489 & 0.500 & 0.000 & 0.000 & 0.000 & 1.000 & 1.000 \\
\hline Urban & 56,276 & 0.438 & 0.496 & 0.000 & 0.000 & 0.000 & 1.000 & 1.000 \\
\hline Age & 56,276 & 37.151 & 14.779 & 18.000 & 25.000 & 34.000 & 46.000 & 79.000 \\
\hline & $\mathrm{N}$ & Mean & SD & P1 & P25 & P50 & P75 & P99 \\
\hline FCR Exposure & 54,423 & 0.185 & 0.389 & 0.000 & 0.000 & 0.000 & 0.000 & 1.000 \\
\hline Satisfied with Local Government & 54,423 & 0.528 & 0.499 & 0.000 & 0.000 & 1.000 & 1.000 & 1.000 \\
\hline Post 2004 & 54,423 & 0.769 & 0.421 & 0.000 & 1.000 & 1.000 & 1.000 & 1.000 \\
\hline Female & 54,423 & 0.492 & 0.500 & 0.000 & 0.000 & 0.000 & 1.000 & 1.000 \\
\hline Urban & 54,423 & 0.428 & 0.495 & 0.000 & 0.000 & 0.000 & 1.000 & 1.000 \\
\hline Age & 54,423 & 37.386 & 14.907 & 18.000 & 26.000 & 34.000 & 46.000 & 79.000 \\
\hline
\end{tabular}

Notes: This table presents descriptive statistics for the perception analyses in Table 4 Panel B We define all variables in Table 4 Panel B The sample is from 1999 to 2015.

\section{Panel B: Regressions}

\begin{tabular}{|c|c|c|c|c|}
\hline & \multicolumn{2}{|c|}{ Corrupt Government } & \multicolumn{2}{|c|}{ Satisfied with Local Government } \\
\hline & (1) & $\begin{array}{c}(2) \\
\text { Including }\end{array}$ & (3) & $\begin{array}{c}(4) \\
\text { Including }\end{array}$ \\
\hline & Baseline & Controls & Baseline & Controls \\
\hline FCR Exposure $\times$ Post 2004 & $\begin{array}{l}-0.043 \\
(0.019)\end{array}$ & $\begin{array}{l}-0.044 \\
(0.019)\end{array}$ & $\begin{array}{c}0.103 \\
(0.025)\end{array}$ & $\begin{array}{c}0.103 \\
(0.025)\end{array}$ \\
\hline FCR Exposure & $\begin{array}{c}-0.002 \\
(0.017)\end{array}$ & $\begin{array}{c}0.005 \\
(0.017)\end{array}$ & $\begin{array}{c}-0.052 \\
(0.024)\end{array}$ & $\begin{array}{c}-0.060 \\
(0.024)\end{array}$ \\
\hline \multicolumn{5}{|l|}{ Controls: } \\
\hline Female & & $\begin{array}{c}-0.021 \\
(0.004)\end{array}$ & & $\begin{array}{c}0.010 \\
(0.004)\end{array}$ \\
\hline Urban & & $\begin{array}{c}0.055 \\
(0.006)\end{array}$ & & $\begin{array}{c}-0.069 \\
(0.007)\end{array}$ \\
\hline $\operatorname{Ln}(A g e)$ & & $\begin{array}{l}-0.019 \\
(0.006)\end{array}$ & & $\begin{array}{c}0.051 \\
(0.006)\end{array}$ \\
\hline \multicolumn{5}{|l|}{ Fixed Effects: } \\
\hline Region $\times$ Year & Yes & Yes & Yes & Yes \\
\hline Commodity & Yes & Yes & Yes & Yes \\
\hline \multicolumn{5}{|l|}{ Standard Error Clusters: } \\
\hline Village & 4,531 & 4,531 & 4,340 & 4,340 \\
\hline Adjusted R-Squared & 0.051 & 0.055 & 0.051 & 0.057 \\
\hline Observations & 56,276 & 56,276 & 54,423 & 54,423 \\
\hline
\end{tabular}

Notes: This table reports coefficient estimates of OLS regressions estimating the effect of the post-2004 increase in FCPA enforcement on the perceived corruption of government officials and the perceived satisfaction with local governments. The sample is from 1999 to 2015. Standard errors clustered at the village level are reported in parentheses. FCR Exposure is a binary indicator equal to one if the closest extraction facility within $100 \mathrm{~km}$ of a survey respondent has at least one significant owner (with an ownership stake of $20 \%$ or more) in 2004 who is headquartered, cross-listed, or operates a segment in the US and is from a signatory country of the OECD Anti-Bribery Convention. Corrupt Government is a binary indicator equal to one if the response value to the following Afrobarometer survey question equals "Most of them" or "All of them": How many of the following people do you think are involved in corruption, or haven't you heard enough about them to say: Government officials?. Satisfied with Local Government is a binary indicator equal to one if the response value to the following Afrobarometer survey question equals "Approve" or "Strongly approve": Do you approve or disapprove of the way the following people have performed their jobs over the past twelve months, or haven't you heard enough about them to say: Your Local Government/official/assembly?. Post 2004 is a binary indicator equal to one for years after 2004. Female is a binary indicator equal to one if the respondent's gender is female. Urban is a binary indicator equal to one if the respondent lives in an urban area. Age is the age of the respondent. 


\section{Table 5: Extraction Activities' Contribution to Economic Growth}

\section{Panel A: Association between World Commodity Prices and Local Commodity Production}

\begin{tabular}{lcc}
\hline \hline & $(1)$ & $(2)$ \\
Dependent Variable: & Ln(Production +1$)$ & $\operatorname{Ln}($ Production +1$)$ \\
\hline Ln(Price) & 0.807 & 0.760 \\
& $(0.351)$ & $(0.343)$ \\
\hline Fixed Effects: & & Yes \\
Property $\times$ Commodity & Yes & No \\
Year & Yes & Yes \\
Region $\times$ Year & No & 7,350 \\
\hline Property-Commodity-Year Observations & 7,350 & \\
\hline
\end{tabular}

Notes: This table reports the coefficient estimates of OLS regressions estimating the association between world commodity prices and property-level production. We describe the sample selection in Internet Appendix Section IA2. The sample is from 2000 to 2013. Conley (1999) standard errors allowing for spatial correlation within a 500km radius and for infinite serial correlation are reported in parentheses. Price (in USD) is the world price of a given commodity in a given year. Production is the reported actual production of the respective commodity (in metric tonnes) in a given year multiplied by the world commodity price in 2000.

\section{Panel B: Foreign Corruption Regulation and the Contribution of Resource Extraction to Development}

\begin{tabular}{|c|c|c|c|c|c|}
\hline \multirow{4}{*}{$\begin{array}{l}\text { Dependent Variable: } \\
\text { Ln(Luminosity }(10)+1)\end{array}$} & \multirow{4}{*}{$\begin{array}{c}\frac{\text { Baseline }}{(1)} \\
0-10 \mathrm{~km} \\
\text { Radius }\end{array}$} & \multicolumn{4}{|c|}{ Sensitivity Analyses } \\
\hline & & $(2)$ & (3) & $(4)$ & $(5)$ \\
\hline & & Asinh & $1-10 \mathrm{~km}$ & Within & USJ Non-OECD \\
\hline & & (Luminosity) & Radius & Region $\times$ Year & and Non-USJ OECD \\
\hline$F C R \times$ Post $2004 \times \operatorname{Ln}($ Price $)$ & $\begin{array}{c}0.020 \\
(0.010)\end{array}$ & & $\begin{array}{c}0.019 \\
(0.010)\end{array}$ & $\begin{array}{c}0.017 \\
(0.010)\end{array}$ & $\begin{array}{c}0.010 \\
(0.004)\end{array}$ \\
\hline$F C R \times \operatorname{Ln}($ Price $)$ & $\begin{array}{l}0.085 \\
(0.070)\end{array}$ & & $\begin{array}{c}0.086 \\
(0.066)\end{array}$ & $\begin{array}{c}0.083 \\
(0.067)\end{array}$ & $\begin{array}{c}0.122 \\
(0.055)\end{array}$ \\
\hline FCR $\times$ Post $2004 \times A \sinh ($ Price $)$ & & $\begin{array}{c}0.026 \\
(0.012)\end{array}$ & & & \\
\hline$F C R \times \operatorname{Asinh}($ Price $)$ & & $\begin{array}{c}0.118 \\
(0.092)\end{array}$ & & & \\
\hline USJ Non-OECD $\times$ Post $2004 \times \operatorname{Ln}($ Price $)$ & & & & & $\begin{array}{l}-0.006 \\
(0.014)\end{array}$ \\
\hline USJ Non-OECD $\times \operatorname{Ln}($ Price $)$ & & & & & $\begin{array}{l}-0.054 \\
(0.053)\end{array}$ \\
\hline Non-USJ OECD $\times$ Post $2004 \times \operatorname{Ln}($ Price $)$ & & & & & $\begin{array}{c}0.004 \\
(0.003)\end{array}$ \\
\hline Non-USJ OECD $\times \operatorname{Ln}($ Price $)$ & & & & & $\begin{array}{c}0.079 \\
(0.046)\end{array}$ \\
\hline Difference in Coefficients (p-value): & & & & & \\
\hline $\begin{array}{l}{[\text { FCR }- \text { USJ Non-OECD }] \times \text { Post } 2004 \times \operatorname{Ln}(\text { Price })} \\
{[\text { FCR }- \text { Non-USJ OECD }] \times \text { Post } 2004 \times \operatorname{Ln}(\text { Price })}\end{array}$ & & & & & $\begin{array}{l}0.26 \\
0.16\end{array}$ \\
\hline Fixed Effects: & & & & & \\
\hline Property $\times$ Commodity & Yes & Yes & Yes & Yes & Yes \\
\hline Region $\times$ Year & No & No & No & Yes & No \\
\hline Commodity $\times$ Year & Yes & Yes & Yes & Yes & Yes \\
\hline $\mathrm{FCR} \times$ Year & Yes & Yes & Yes & Yes & Yes \\
\hline Property-Commodity-Year Observations & 8,694 & 8,694 & 8,694 & 8,694 & 8,694 \\
\hline
\end{tabular}

Notes: This table reports coefficient estimates of OLS regressions estimating the effect of the post-2004 increase in FCPA enforcement on the association between world commodity prices and nighttime luminosity. We describe the sample selection in Internet Appendix Section IA2. The sample is from 2000 to 2013. Conley (1999) standard errors allowing for spatial correlation within a 500km radius and for infinite serial correlation are reported in parentheses. Luminosity (10) is the stable light mean unsaturated nighttime luminosity within a $10 \mathrm{~km}$ radius of the respective property. Luminosity (1-10) is the stable light mean unsaturated nighttime luminosity within a $1-10 \mathrm{~km}$ radius of the respective property. $F C R$ is a binary indicator equal to one if an extraction facility has at least one significant owner (with an ownership stake of $20 \%$ or more) in 2004 who is headquartered, cross-listed, or operates a segment in the US and is from a signatory country of the OECD Anti-Bribery Convention. USJ Non-OECD is a binary indicator equal to one if a property has at least one significant owner (with an ownership stake of $20 \%$ or more) in 2004 who is cross-listed or operates a segment in the US but is not from a signatory country of the OECD Anti-Bribery Convention. Non-USJ OECD is a binary indicator equal to one if a property has at least one significant owner (with an ownership stake of $20 \%$ or more) in 2004 who is from a signatory country of the OECD Anti-Bribery Convention but is not cross-listed and does not operate a segment in the US. Post 2004 is a binary indicator equal to one for years after 2004. Price (in USD) is the world price of a given commodity in a given year. 
For Online Publication

\title{
Reversing the Resource Curse: \\ Foreign Corruption Regulation and Economic Development
}

\author{
By Hans B. Christensen, Mark Maffett, and Thomas RaUter
}

December 2020

\section{Table of Contents}

Section IA1: Reasons for and Timing of the FCPA Enforcement Increase

IA1.1: Reasons for the FCPA Enforcement Increase after 2004

IA1.2: Revealed Corporate Awareness of the FCPA Enforcement Increase

Section IA2: Sample and Composition

IA2.1 Sample Selection Criteria

IA2.2 Sample Composition by Commodity

IA2.3 Sample Composition by Facility Country and Region

IA2.4 Sample Composition by Owner Country

Section IA3: Supplementary Tests for Luminosity Analyses

IA3.1 Jackknife Procedure Excluding Individual Commodities

IA3.2 Excluding Overlapping Extraction Areas

IA3.3 Keeping only the Main Commodity

IA3.4 Ln(Luminosity) as an Alternative Outcome Variable

IA3.5 Placebo Treatment Effects

IA3.6 Controlling for Economic Conditions in Headquarter Countries

Section IA4: Changes in the Size of the Extraction Sector

Section IA5: Supplementary Tests for Analyses of Changes in the Extraction Sector

IA5.1 Composition of Afrobarometer Survey Sample

IA5.2 Commodity Price Variation

Section IA6: New Firms Entering the Extraction Sector

Section IA7: How Firms Operate without Paying Bribes 


\section{Section IA1: Reasons for and Timing of the FCPA Enforcement Increase}

\section{IA1.1: Reasons for the FCPA Enforcement Increase after 2004 ${ }^{1}$}

Figure IA1.1 plots the total number of FCPA enforcement actions per year from 1977 to 2017 . We collect all enforcement actions against corporations from the Stanford Law School FCPA Database. FCPA cases increase sharply after 2005. The first spike in enforcement actions occurs in 2007, which, given that a typical FCPA investigation, from initiation until the filing of an enforcement action, takes multiple years, is consistent with an onset of the ramp up in enforcement around 2005. Importantly, SEC-registered firms are generally required to publicly disclose FCPA investigations when they become aware of them. Evidence in Cassin (2018) suggests that public disclosure typically occurs a few years before cases are resolved. From 1977 until 2004 there were 53 FCPA enforcement actions (fewer than 2 per year); since then, there have been 284 cases (more than 20 per year).

Figure IA1.1: FCPA Enforcement Actions from 1977 to 2017

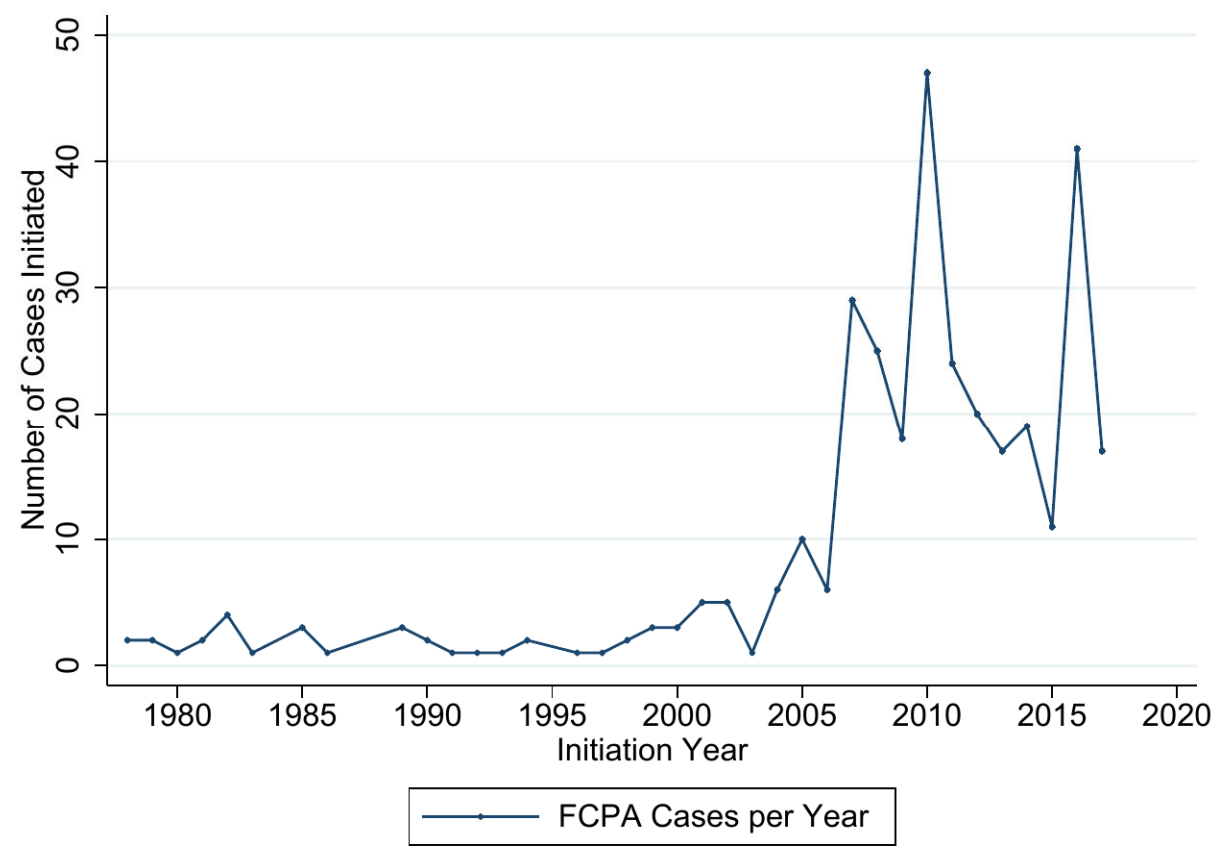

Notes: This figure shows the annual number of FCPA enforcement actions filed by the SEC and DOJ against corporations from 1977 to 2017.

A confluence of factors, all occurring in 2004, help to explain the timing of the FCPA enforcement increase. Below, we discuss these factors in detail.

United States v. Kay

A 2004 ruling by the US Court of Appeals in United States $v$. Kay expanded the legal definition of a bribe paid to "obtain or retain" business, and thereby broadened the scope of the FCPA beyond

\footnotetext{
1 The discussion in this section is based on Christensen et al. (2020): "Policeman for the World: The Impact of Extraterritorial FCPA Enforcement on Foreign Investment and Internal Controls."
} 
government procurement contracts to include a variety of potential interactions with public officials when conducting business abroad (e.g., payments for customs duties, licenses, permits, taxes, etc.). Consistent with the importance of the Kay decision, Martin et al. (2012) find that, compared to the period from 1977 to 2004, the percentage of FCPA enforcement actions targeting activities besides government procurement contracts nearly doubled after 2005 .

\section{Deferred Prosecution and Non-Prosecution Agreements}

In late 2004, the DOJ used a non-prosecution agreement for the first time in a case against InVision Technologies and General Electric. Previously, the DOJ relied on filing formal charges as its only FCPA enforcement option. In January of 2005, the DOJ, again for the first time, employed a deferred-prosecution agreement in a case against Monsanto. These alternative resolution vehicles forgo formal charges in favor of allowing the accused to acknowledge wrongdoing, pay a monetary penalty, and prospectively demonstrate good conduct. The possibility of using these agreements greatly reduced the likelihood that the DOJ would have to fulfill the burden of proof in court, and thus increased the agency's willingness to pursue cases.

Although the possibility of using deferred and non-prosecution agreements existed before 2005, their usage in FCPA cases beginning in 2004 appears to reflect a change in tactics by the DOJ. Mark Mendelsohn, the former deputy chief of the DOJ's FCPA enforcement unit, whose tenure at the DOJ began in 2005, stated publicly that if the agency did not have the option of resolving FCPA enforcement cases with non-prosecution or deferred-prosecution agreements, it would "certainly bring fewer cases" (Corporate Crime Reporter 2010). Consistent with this argument, Martin et al. (2012) show that since 2004 the DOJ has resolved $75 \%$ of all corporate FCPA enforcement actions with non- or deferred-prosecution agreements.

\section{The Sarbanes-Oxley Act (SOX)}

Regulatory changes arising from SOX increased the consequences to firms and their senior corporate officers for failing to maintain adequate internal control systems, such as those required under the FCPA's accounting provisions (98\% of all successful FCPA cases after 2005 involve violations of the FCPA's accounting provisions. see Christensen et al. 2020 for further details). SOX Section 404, which became effective in November 2004 (for most firms), requires SEC registrants and their external auditors to assess the effectiveness of firms' internal control systems, including the firm's FCPA compliance programs, and to publicly disclose the results in the auditor's report. Increased scrutiny under SOX made it more likely that internal control failures and questionable transactions would be detected. An increased awareness of potential improprieties, coupled with the requirement under SOX Section 302 that senior corporate officers certify the accuracy of the firm's financial statements, increased the incentives for managers to self-report potential FCPA violations. Because the SEC and DOJ consider the extent of a company's cooperation, self-reporting misconduct upon discovery can also lead to less severe sanctions (SEC and DOJ 2012).

The DOJ has referenced SOX Sections 404 and 302 as important drivers of the increase in FCPA enforcement. During a 2010 Senate FCPA hearing a DOJ representative stated: "We are getting a significant number of disclosures from corporations about their own criminal conduct. I think that, in part, relates to the passage of Sarbanes-Oxley legislation, which encourages corporations to review their own books and records." In 2011 the same official stated "...one likely cause for this increase in cases is disclosures by companies consistent with their obligations under the Sarbanes- 
Oxley Act, which requires senior corporate officers to certify the accuracy of their financial statements. This has led to more companies discovering FCPA violations and making the decision to disclose them to the SEC and DOJ" (Koehler 2019).

\section{IA1.2: Revealed Corporate Awareness of the FCPA Enforcement Increase}

The three regulatory events discussed in Section IA1.1 can explain why FCPA enforcement actions increased after 2004. A related question is when multinational firms became aware of the FCPA enforcement increase and, hence, when the deterrent effect started to materialize. One empirical approach to assess when firms became aware of the enforcement threat is to examine the timing of changes in corporate policies that (i) respond to increased enforcement of foreign corruption regulation and (ii) are relatively easy to adjust and hence are expected to occur soon after firms become aware of an increase in enforcement.

The level of new investments in high-corruption-risk countries is a relatively fast-moving outcome that we expect to change when firms become aware of the increase in FCPA enforcement. Since forgoing marginal investment opportunities likely does not entail significant adjustment costs, multinational firms can quickly change their investments in a given host country. Zeume (2017) and Sanseverino (2020) find that multinational firms slow their expansion to high-corruption-risk countries almost immediately after an increase in anti-corruption enforcement due to the passage of the UK Bribery Act. Based on these papers, we gauge when multinational firms likely became aware of the increase in FCPA enforcement by looking at when their new investments in highcorruption-risk countries change relative to their investments in low-corruption-risk countries.

To do so, we compare changes in bilateral foreign direct investment (FDI) flows for firms headquartered in OECD countries (that are subject to the FCPA because their home country signed the OECD Anti-Bribery Convention) versus non-OECD firms in high-versus low-corruption-risk countries. We use the same data sources and essentially the same empirical model (excluding control variables) as in Christensen et al. (2020). In Figure IA1.2, we plot the yearly coefficient estimates of the treatment effect relative to 2001, which serves as the benchmark year. Before 2005, OECD firms have almost identical patterns in FDI flows as non-OECD firms. However, starting in 2005, OECD firms sharply curtail their new investments in high-corruption-risk countries. This decrease in FDI flows persists through the end of our sample period.

Taken together, the timing of the investment reduction suggests that multinational firms subject to the FCPA became aware of the enforcement increase beginning in 2005. Thus, we choose 2005 as the onset of the treatment period (i.e., when the deterrent effect of the FCPA most likely starts to materialize for our sample firms). 
Figure IA1.2: Foreign Investments in High-Corruption-Risk Areas around FCPA Enforcement Increase

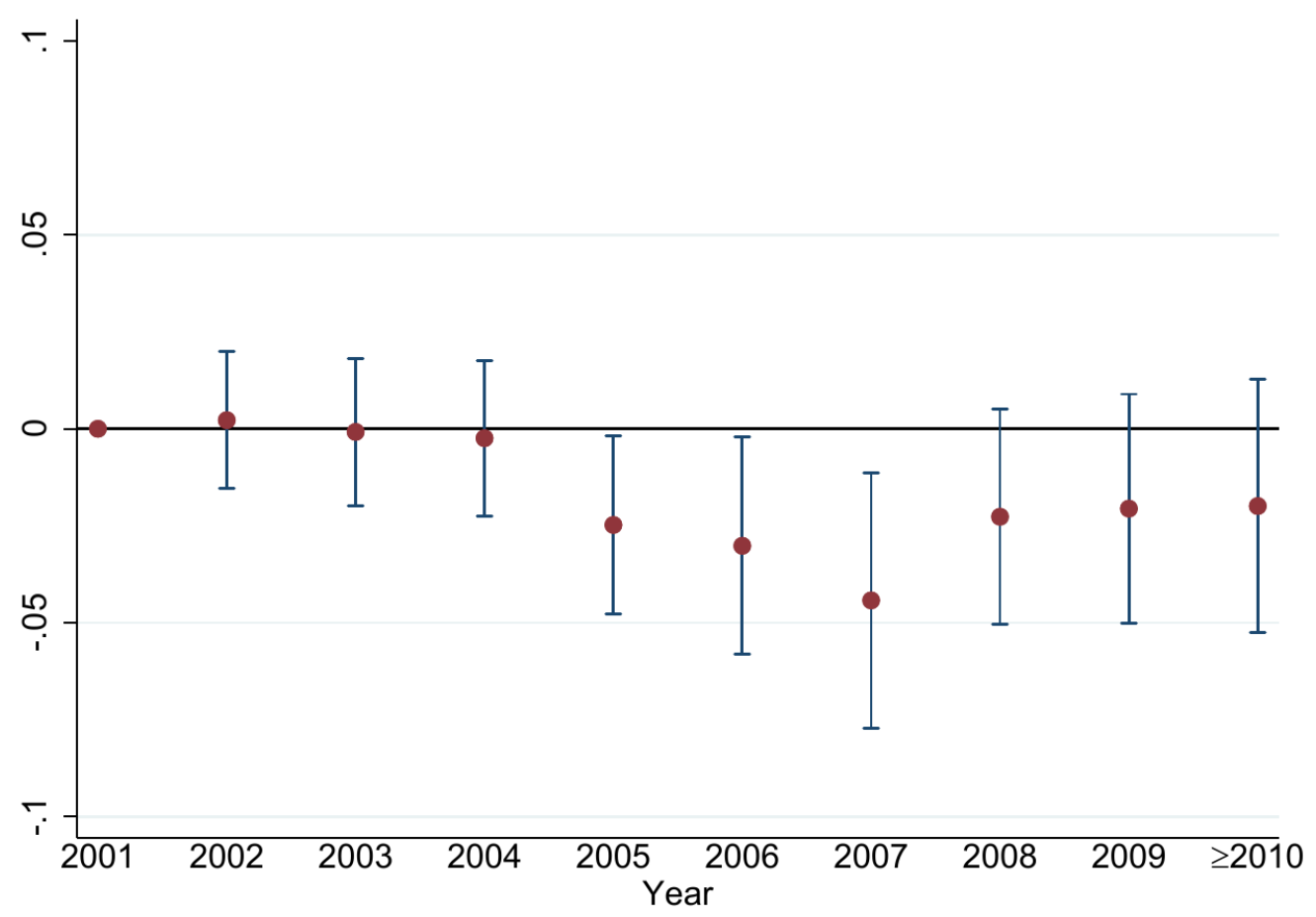

Notes: This figure shows coefficient estimates and 95\% confidence intervals for OLS regressions estimating the effect of increased FCPA enforcement on foreign direct investments in highcorruption-risk countries. 


\section{Section IA2: Sample Selection and Composition}

\section{IA2.1 Sample Selection Criteria}

In Table IA2.1, we describe how we construct the sample for our luminosity analyses and provide a breakdown of the number of observations affected by each step of the sample selection for the mining facilities (Panel A) and the oil and gas facilities (Panel B).

For the mining sample (Table IA2.1 Panel A), there are 3,842 extraction facilities in the $S N L$ Database in December 2018. However, most of the extraction sites $(3,355)$ report zero production for our sample period (2000 to 2013). After excluding these facilities, we have 487 unique facilities and 186 of these facilities extract two minerals. We perform the main analysis at the facility $\times$ mineral level and when we account for multiple minerals at the same facility, we have 673 facility-mineral observations (we provide results only including the main mineral in Section IA3.3). For each facility, we have 14 years of data and we exclude facilities without price data and singletons. After applying all selection criteria, the baseline mine-mineral-year sample consist of 8,736 observations.

For the oil and gas sample (Table IA2.1 Panel B), there are 3,026 wells in the Enverus International database in June 2019. However, after excluding duplicates, wells without location data, and wells that opened after 2004 (i.e., the year before treatment), there are 2,404 wells. Oil and gas wells are often located close together in blocks, which makes it difficult to isolate each well's contribution to growth. To address this issue, we exclude blocks with multiple owners (2,132 wells). We further exclude offshore wells because our measure of growth makes little sense for non-land environments. Finally, we exclude abandoned, shut in, depleted and newly discovered wells, as well as, one well for which we have no luminosity data, which results in 113 wells left in our final sample. Again, for each well we have 14 years of data and exclude facilities without price data and singletons. After applying all selection criteria, the baseline oil well sample consists of 1,582 observations.

Our combined sample of mining and oil facilities consists of $10,318(8,736+1,582)$ observations. 


\section{Table IA2.1: Sample Selection Criteria}

\section{Panel A: Mining Sample}

\begin{tabular}{lcc}
\hline \hline & & \\
& & Mine \\
Sample Selection Step & $\begin{array}{c}\text { Lumity } \\
\text { Observations }\end{array}$ & $\Delta$ \\
\hline Raw mine level data (downloaded from the SNL Database in Dec. 2018) & 3,842 & \\
(1) Raw mine observations & 487 & $-3,355$ \\
(2) Excluding mines with zero reported production from 2000 to 2013 & +186 \\
(3) Adding observations for mines that produce multiple minerals & 673 & \\
Luminosity data & & 9,422 \\
(4) Luminosity observations at the mine-mineral-year level & 8,778 & -644 \\
(5) Excluding minerals with no price data & 8,736 & -42 \\
(6) Excluding singletons & & 8,736 \\
\hline Final baseline sample of mine-mineral-year observations & & \\
\hline
\end{tabular}

\section{Panel B: Oil and Gas Sample}

\begin{tabular}{|c|c|c|c|}
\hline Sample Selection Step & $\begin{array}{c}\text { Oil Well } \\
\text { Observations }\end{array}$ & $\begin{array}{l}\text { Luminosity } \\
\text { Observations }\end{array}$ & $\Delta$ \\
\hline \multicolumn{4}{|l|}{ Raw oil well data (downloaded from Enverus International in June 2019) } \\
\hline (1) Raw oil well observations & 3,026 & & \\
\hline (2) Excluding duplicate observations & 3,021 & & -5 \\
\hline (3) Excluding observations with no location data & 3,012 & & -9 \\
\hline (4) Excluding wells discovered after 2004 & 2,404 & & -608 \\
\hline (5) Excluding wells located in blocks where multiple firms operate & 272 & & $-2,132$ \\
\hline (6) Excluding offshore wells & 193 & & -79 \\
\hline (8) Excluding abandoned, shut in, depleted, or discovery wells & 114 & & -79 \\
\hline (9) Excluding wells with no luminosity data & 113 & & -1 \\
\hline \multicolumn{4}{|l|}{ Luminosity data } \\
\hline (10) Luminosity observations at the well-year level & & 1,582 & $\times 14$ \\
\hline Final baseline sample of well-year observations & & 1,582 & \\
\hline
\end{tabular}

Notes: This table describes the sample selection process for our luminosity analyses. The sample is from 2000 to 2013. 


\section{IA2.2 Sample Composition by Commodity}

Table IA2.2 reports the distribution of extraction facilities across commodity types. Our sample includes facilities that extract 20 different commodities, with the largest concentration in gold (23\%), followed by coal (14\%), and oil (13\%).

Table IA2.2: Sample Composition by Commodity

\begin{tabular}{lcccccc}
\hline \hline Unique & $\begin{array}{c}\text { Unique Foreign } \\
\text { Properties }\end{array}$ & $\begin{array}{c}\text { Unique USJ } \\
\text { Properties }\end{array}$ & $\begin{array}{c}\text { Unique } \\
\text { FCR } \\
\text { Properties }\end{array}$ & $\begin{array}{c}\text { Property-Year } \\
\text { Observations }\end{array}$ & $\begin{array}{c}\text { FCR } \\
\text { Property-Year } \\
\text { Observations }\end{array}$ \\
\hline Aluminum & 5 & 3 & 2 & 2 & 70 & 28 \\
Chromite & 18 & 10 & 10 & 8 & 252 & 112 \\
Coal & 102 & 35 & 46 & 31 & 1,428 & 434 \\
Cobalt & 22 & 15 & 9 & 5 & 308 & 70 \\
Copper & 73 & 37 & 28 & 13 & 1,022 & 182 \\
Diamond & 85 & 43 & 9 & 1 & 1,190 & 14 \\
Gas & 14 & 1 & 1 & 1 & 196 & 14 \\
Gold & 170 & 78 & 87 & 28 & 2,380 & 392 \\
Iron & 19 & 2 & 6 & 2 & 266 & 28 \\
Lead & 7 & 5 & 5 & 3 & 98 & 42 \\
Manganese & 11 & 5 & 3 & 2 & 154 & 28 \\
Nickel & 36 & 11 & 13 & 2 & 504 & 28 \\
Oil & 99 & 19 & 7 & 4 & 1,386 & 56 \\
Phosphate & 4 & 0 & 0 & 0 & 56 & 0 \\
Platinum & 39 & 12 & 15 & 1 & 546 & 14 \\
Silver & 12 & 7 & 3 & 1 & 168 & 0 \\
Tantalum & 3 & 0 & 0 & 0 & 42 & 28 \\
Vanadium & 3 & 2 & 2 & 2 & 42 & 84 \\
Zinc & 11 & 8 & 9 & 6 & 154 & 28 \\
Zircon & 4 & 3 & 2 & 2 & 56 & 1,596 \\
\hline Total & 737 & 296 & 257 & 114 & 10,318 & \\
\hline
\end{tabular}

Notes: This table presents descriptive statistics by commodity for our luminosity sample. We describe the sample selection in Internet Appendix Section IA2. The sample is from 2000 to 2013. FCR properties have at least one significant owner (with an ownership stake of $20 \%$ or more) in 2004 who is headquartered, cross-listed, or operates a segment in the US and is from a signatory country of the OECD Anti-Bribery Convention.

\section{IA2.3 Sample Composition by Facility Country and Region}

Table IA2.3 provides descriptive statistics on the sample composition by facility country (Panel A) and facility region (Panel B). Of note is the fact that, within many countries, there are relatively few treated and control properties. Indeed, in 14 countries there are no treated properties and in 7 countries there is only one treated property. However, within region there is much more variation in treated and control properties. Northern Africa has the lowest fraction of treated properties $(4.80 \%)$ and East Africa has the highest fraction of treated properties $(26.74 \%)$. The lack of treated properties in many African countries is why we do not include Country $\times$ Year fixed effects and instead report results with Region $\times$ Year fixed effects. 
Table IA2.3: Sample Composition by Country and Region Panel A: By Country

\begin{tabular}{|c|c|c|c|}
\hline & $\begin{array}{c}\text { Unique } \\
\text { Properties }\end{array}$ & $\begin{array}{c}\text { Treated } \\
\text { Properties }\end{array}$ & $\begin{array}{c}\% \text { Treated } \\
\text { Properties } \\
\text { within Country }\end{array}$ \\
\hline Algeria & 31 & 2 & 6.45 \\
\hline Angola & 10 & 1 & 10.00 \\
\hline Botswana & 21 & 1 & 4.76 \\
\hline Burkina Faso & 11 & 2 & 18.18 \\
\hline Cote d'Ivoire & 6 & 0 & 0.00 \\
\hline Dem. Rep. Congo & 36 & 7 & 19.44 \\
\hline Egypt & 11 & 0 & 0.00 \\
\hline Eritrea & 4 & 0 & 0.00 \\
\hline Ethiopia & 2 & 0 & 0.00 \\
\hline Gabon & 7 & 1 & 14.29 \\
\hline Ghana & 17 & 5 & 29.41 \\
\hline Guinea & 9 & 1 & 11.11 \\
\hline Lesotho & 3 & 0 & 0.00 \\
\hline Liberia & 1 & 0 & 0.00 \\
\hline Libya & 57 & 2 & 3.51 \\
\hline Madagascar & 3 & 2 & 66.67 \\
\hline Mali & 9 & 3 & 33.33 \\
\hline Mauritania & 6 & 3 & 50.00 \\
\hline Morocco & 13 & 0 & 0.00 \\
\hline Mozambique & 5 & 1 & 20.00 \\
\hline Namibia & 20 & 1 & 5.00 \\
\hline Niger & 2 & 0 & 0.00 \\
\hline Nigeria & 7 & 0 & 0.00 \\
\hline Senegal & 1 & 1 & 100.00 \\
\hline Sierra Leone & 8 & 0 & 0.00 \\
\hline South Africa & 351 & 59 & 16.81 \\
\hline Sudan & 2 & 0 & 0.00 \\
\hline Swaziland & 1 & 0 & 0.00 \\
\hline Tanzania & 12 & 6 & 50.00 \\
\hline Tunisia & 10 & 2 & 20.00 \\
\hline Uganda & 1 & 0 & 0.00 \\
\hline Western Sahara & 1 & 0 & 0.00 \\
\hline Zambia & 23 & 7 & 30.43 \\
\hline Zimbabwe & 36 & 7 & 19.44 \\
\hline Total & 737 & 114 & \\
\hline
\end{tabular}

Panel B: By Region

\begin{tabular}{lccc}
\hline \hline & & & Unique \\
& $\begin{array}{c}\text { Treated } \\
\text { Properties }\end{array}$ & $\begin{array}{c}\text { Properties } \\
\text { Properties }\end{array}$ & $\begin{array}{c}\text { Prithin Region } \\
\text { with }\end{array}$ \\
\hline East Africa & 86 & 23 & 26.74 \\
Middle Africa & 53 & 9 & 16.98 \\
North Africa & 125 & 6 & 4.80 \\
Southern Africa & 396 & 61 & 15.40 \\
West Africa & 77 & 15 & 19.48 \\
\hline Total & 737 & 114 & \\
\hline
\end{tabular}

Notes: This table presents descriptive statistics by country and region for our luminosity sample. We describe the sample selection in Internet Appendix Section IA2. The sample is from 2000 to 2013. Treated properties have at least one significant owner (with an ownership stake of $20 \%$ or more) in 2004 who is headquartered, cross-listed, or operates a segment in the US and is from a signatory country of the OECD Anti-Bribery Convention. 


\section{IA2.4 Sample Composition by Owner Country}

Table IA2.4 reports the number of facility owners by headquarter country and treatment or control group. We focus on parent companies with an ownership stake in the given extraction facility of at least $20 \%$ in 2004. Most of our treated properties are owned by firms located in Canada (27\%), the United Kingdom (25\%), Switzerland (19\%), Australia (14\%), and the US (6\%). Properties owned by domestic firms that are neither subject to US jurisdiction nor located in the OECD are primarily from South Africa (43\%), Libya (13\%), Algeria (6\%), the Democratic Republic of Congo (5\%), and Zimbabwe (4\%).

Table IA2.4: Sample Composition by Owner Country

\begin{tabular}{|c|c|c|c|c|c|}
\hline Owner Country & $\begin{array}{c}\text { FCR } \\
\text { Properties }\end{array}$ & $\begin{array}{l}\text { USJ Non-OECD } \\
\text { Properties }\end{array}$ & $\begin{array}{c}\text { Non-USJ OECD } \\
\text { Properties }\end{array}$ & $\begin{array}{l}\text { Non-USJ Non-OECD } \\
\text { Foreign Properties }\end{array}$ & $\begin{array}{l}\text { Non-USJ Non-OECD } \\
\text { Domestic Properties }\end{array}$ \\
\hline Algeria & 0 & 0 & 0 & 0 & 26 \\
\hline Angola & 0 & 0 & 0 & 0 & 7 \\
\hline Australia & 16 & 0 & 17 & 0 & 0 \\
\hline Austria & 0 & 0 & 1 & 0 & 0 \\
\hline Barbados & 0 & 0 & 0 & 2 & 0 \\
\hline Bermuda & 0 & 13 & 0 & 1 & 0 \\
\hline Botswana & 0 & 0 & 0 & 0 & 12 \\
\hline Brazil & 1 & 0 & 1 & 0 & 0 \\
\hline British Virgin Islands & 0 & 0 & 0 & 4 & 0 \\
\hline Burkina Faso & 0 & 0 & 0 & 0 & 1 \\
\hline Canada & 31 & 0 & 31 & 0 & 0 \\
\hline Cayman Islands & 0 & 0 & 0 & 1 & 0 \\
\hline China & 0 & 3 & 0 & 2 & 0 \\
\hline Cote d'Ivoire & 0 & 0 & 0 & 0 & 1 \\
\hline Cyprus & 0 & 0 & 0 & 1 & 0 \\
\hline Dem. Rep. Congo & 0 & 0 & 0 & 0 & 20 \\
\hline Egypt & 0 & 0 & 0 & 0 & 9 \\
\hline Eritrea & 0 & 0 & 0 & 0 & 4 \\
\hline Ethiopia & 0 & 0 & 0 & 0 & 2 \\
\hline France & 3 & 0 & 3 & 0 & 0 \\
\hline Gabon & 0 & 0 & 0 & 0 & 2 \\
\hline Germany & 0 & 0 & 1 & 0 & 0 \\
\hline Ghana & 0 & 0 & 0 & 0 & 4 \\
\hline Guinea & 0 & 0 & 0 & 0 & 5 \\
\hline Indonesia & 0 & 0 & 0 & 2 & 0 \\
\hline Ireland & 0 & 0 & 1 & 0 & 0 \\
\hline Italy & 4 & 0 & 0 & 0 & 0 \\
\hline Lesotho & 0 & 0 & 0 & 0 & 2 \\
\hline Liberia & 0 & 0 & 0 & 0 & 1 \\
\hline Libya & 0 & 0 & 0 & 0 & 53 \\
\hline Luxembourg & 1 & 0 & 20 & 0 & 0 \\
\hline Madagascar & 0 & 0 & 0 & 0 & 1 \\
\hline Mali & 0 & 0 & 0 & 0 & 8 \\
\hline Malta & 0 & 0 & 0 & 2 & 0 \\
\hline Mauritania & 0 & 0 & 0 & 0 & 3 \\
\hline Morocco & 0 & 0 & 0 & 0 & 13 \\
\hline Mozambique & 0 & 0 & 0 & 0 & 3 \\
\hline Namibia & 0 & 0 & 0 & 0 & 12 \\
\hline Netherlands & 0 & 0 & 4 & 0 & 0 \\
\hline Niger & 0 & 0 & 0 & 0 & 1 \\
\hline Nigeria & 0 & 0 & 0 & 1 & 6 \\
\hline Portugal & 0 & 0 & 1 & 0 & 0 \\
\hline Russia & 0 & 0 & 0 & 3 & 0 \\
\hline Sierra Leone & 0 & 0 & 0 & 0 & 7 \\
\hline South Africa & 0 & 123 & 0 & 6 & 177 \\
\hline Sudan & 0 & 0 & 0 & 0 & 2 \\
\hline Swaziland & 0 & 0 & 0 & 0 & 1 \\
\hline Switzerland & 22 & 0 & 2 & 0 & 0 \\
\hline Tanzania & 0 & 0 & 0 & 0 & 4 \\
\hline Tunisia & 0 & 0 & 0 & 0 & 5 \\
\hline USA & 7 & 0 & 0 & 0 & 0 \\
\hline Uganda & 0 & 0 & 0 & 0 & 1 \\
\hline United Arab Emirates & 0 & 0 & 0 & 2 & 0 \\
\hline United Kingdom & 29 & 0 & 26 & 0 & 0 \\
\hline Western Sahara & 0 & 0 & 0 & 0 & 1 \\
\hline Zambia & 0 & 0 & 0 & 1 & 3 \\
\hline Zimbabwe & 0 & 0 & 0 & 0 & 18 \\
\hline
\end{tabular}

Notes: This table presents descriptive statistics by owner country for our luminosity sample. We consider the headquarter country of all owners with an ownership stake of $20 \%$ or more in 2004. If ownership information of a property is missing, we consider the property to be domestically owned. 


\section{Section IA3: Supplementary Tests for Luminosity Analyses}

\section{IA3.1 Jackknife Procedure Excluding Individual Commodities}

In Table IA3.1, we present results dropping each commodity from the sample in turn. Excluding the two commodities with the largest number of observations, coal and gold (see Table IA2.2), significantly impacts the estimated treatment effects. Excluding coal increases the estimated treatment effect and excluding gold decreases it.

Table IA3.1: Jackknife Procedure Excluding Individual Commodities

\begin{tabular}{|c|c|c|c|c|c|c|c|c|c|c|}
\hline Dependent Variable: $\operatorname{Ln}($ Luminosity $(10)+1)$ & $\begin{array}{c}(1) \\
\text { Excluding } \\
\text { Aluminum }\end{array}$ & $\begin{array}{c}(2) \\
\text { Excluding } \\
\text { Chromite }\end{array}$ & $\begin{array}{c}(3) \\
\text { Excluding } \\
\text { Coal }\end{array}$ & $\begin{array}{c}(4) \\
\text { Excluding } \\
\text { Cobalt }\end{array}$ & $\begin{array}{c}(5) \\
\text { Excluding } \\
\text { Copper }\end{array}$ & $\begin{array}{c}6) \\
\text { Excluding } \\
\text { Diamond }\end{array}$ & $\begin{array}{c}(7) \\
\text { Excluding } \\
\text { Gas }\end{array}$ & $\begin{array}{l}(8) \\
\text { Excluding } \\
\text { Gold }\end{array}$ & $\begin{array}{c}(9) \\
\text { Excluding } \\
\text { Iron }\end{array}$ & $\begin{array}{c}(10) \\
\text { Excluding } \\
\text { Lead }\end{array}$ \\
\hline FCR $\times$ Post 2004 & $\begin{array}{c}0.136 \\
(0.041)\end{array}$ & $\begin{array}{c}0.132 \\
(0.042)\end{array}$ & $\begin{array}{c}0.186 \\
(0.049)\end{array}$ & $\begin{array}{c}0.142 \\
(0.042)\end{array}$ & $\begin{array}{c}0.117 \\
(0.041)\end{array}$ & $\begin{array}{c}0.138 \\
(0.041)\end{array}$ & $\begin{array}{c}0.125 \\
(0.039)\end{array}$ & $\begin{array}{c}0.068 \\
(0.041)\end{array}$ & $\begin{array}{c}0.136 \\
(0.041)\end{array}$ & $\begin{array}{c}0.143 \\
(0.041)\end{array}$ \\
\hline $\begin{array}{l}\text { Fixed Effects: } \\
\text { Property } \times \text { Commodity }\end{array}$ & Yes & Yes & Yes & Yes & Yes & Yes & Yes & Yes & Yes & Yes \\
\hline Region $\times$ Year & No & No & No & No & No & No & No & No & No & No \\
\hline Commodity $\times$ Year & Yes & Yes & Yes & Yes & Yes & Yes & Yes & Yes & Yes & Yes \\
\hline Property-Commodity-Year Observations & 10,248 & 10,066 & 8,890 & 10,010 & 9,296 & 9,128 & 10,122 & 7,938 & 10,052 & 10,220 \\
\hline
\end{tabular}

\begin{tabular}{|c|c|c|c|c|c|c|c|c|c|c|}
\hline Dependent Variable: $\operatorname{Ln}($ Luminosity $(10)+1)$ & $\begin{array}{c}(1) \\
\text { Excluding } \\
\text { Manganese }\end{array}$ & $\begin{array}{c}(2) \\
\text { Excluding } \\
\text { Nickel }\end{array}$ & $\begin{array}{c}(3) \\
\text { Excluding } \\
\text { Oil }\end{array}$ & $\begin{array}{c}(4) \\
\text { Excluding } \\
\text { Phosphate }\end{array}$ & \begin{tabular}{l}
\multicolumn{1}{c}{$(5)$} \\
Excluding \\
Platinum
\end{tabular} & $\begin{array}{c}(6) \\
\text { Excluding } \\
\text { Silver }\end{array}$ & $\begin{array}{c}(7) \\
\text { Excluding } \\
\text { Tantalum }\end{array}$ & $\begin{array}{c}(8) \\
\text { Excluding } \\
\text { Vanadium }\end{array}$ & $\begin{array}{c}(9) \\
\text { Excluding } \\
\text { Zinc }\end{array}$ & $\begin{array}{c}(10) \\
\text { Excluding } \\
\text { Zircon }\end{array}$ \\
\hline FCR $\times$ Post 2004 & $\begin{array}{c}0.136 \\
(0.041)\end{array}$ & $\begin{array}{c}0.134 \\
(0.041)\end{array}$ & $\begin{array}{c}0.145 \\
(0.042)\end{array}$ & $\begin{array}{c}0.136 \\
(0.040)\end{array}$ & $\begin{array}{c}0.136 \\
(0.041)\end{array}$ & $\begin{array}{c}0.142 \\
(0.040)\end{array}$ & $\begin{array}{c}0.136 \\
(0.040)\end{array}$ & $\begin{array}{c}0.135 \\
(0.041)\end{array}$ & $\begin{array}{c}0.144 \\
(0.042)\end{array}$ & $\begin{array}{c}0.139 \\
(0.041)\end{array}$ \\
\hline Fixed Effects: & & & & & & & & & & \\
\hline Property $\times$ Commodity & Yes & Yes & Yes & Yes & Yes & Yes & Yes & Yes & Yes & Yes \\
\hline Region $\times$ Year & No & No & No & No & No & No & No & No & No & No \\
\hline Commodity $\times$ Year & Yes & Yes & Yes & Yes & Yes & Yes & Yes & Yes & Yes & Yes \\
\hline Property-Commodity-Year Observations & 10,164 & 9,814 & 8,932 & 10,262 & 9,772 & 10,150 & 10,276 & 10,276 & 10,164 & 10,262 \\
\hline
\end{tabular}

Notes: This table reports coefficient estimates of OLS regressions estimating the effect of the post-2004 increase in FCPA enforcement on nighttime luminosity. We estimate the model from Column (1) of Table 3 in the Manuscript, but separately exclude individual commodities. We describe the sample selection in Internet Appendix Section IA2. The sample is from 2000 to 2013. Conley (1999) standard errors allowing for spatial correlation within a 500km radius and for infinite serial correlation are reported in parentheses. Luminosity (10) is the stable light mean unsaturated nighttime luminosity within a $10 \mathrm{~km}$ radius of the respective property, $F C R$ is a binary indicator equal to one if an extraction facility has at least one significant owner (with an ownership stake of $20 \%$ or more) in 2004 who is headquartered, cross-listed, or operates a segment in the US and is from a signatory country of the OECD Anti-Bribery Convention. Post 2004 is a binary indicator equal to one for years after 2004.

In Figure IA3.1, we plot the treatment effect of the FCPA on luminosity in event time excluding gold. In the pre-treatment period, there are no statistically significant differences between the treatment and control groups. In the post-treatment period, the path looks similar to the baseline specification including gold (reported in the Manuscript in Figure 2 Panel A) but the magnitude of the estimated treatment effects is generally lower. 
Figure IA3.1: Luminosity Effects in Event-Time Excluding Gold

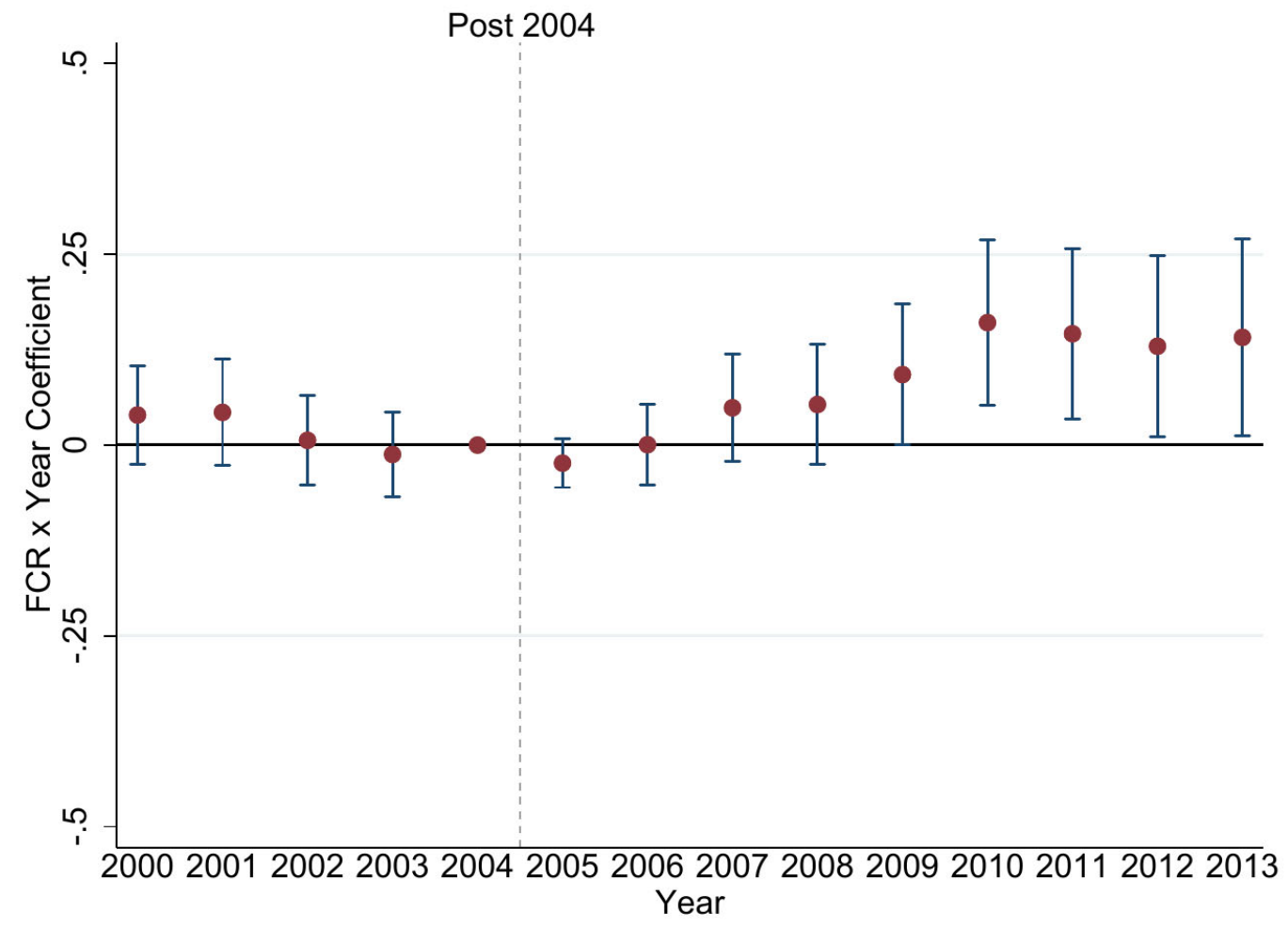

Notes: This figure shows coefficient estimates and 95\% confidence intervals for OLS regressions estimating the effect of the post-2004 increase in FCPA enforcement on nighttime luminosity. We estimate the model from Column (1) of Table 3 in the Manuscript but exclude extraction areas around gold mines and replace the FCR $\times$ Post 2004 indicator with separate interactions for each of the years in our sample (except for 2004, which serves as the benchmark). 


\section{IA3.2 Excluding Overlapping Extraction Areas}

In the Manuscript, our main unit of observation is the 10-kilometer circular geographic area around an active extraction facility. For facilities located near each other, these areas might overlap. When the observed increase in luminosity in treated areas spills over to overlapping control areas, measurement error is introduced and our estimated treatment effects understate the development effects of foreign corruption regulation. In Figure IA3.2 and Table IA3.2, we assess the effect of treatment spillovers by excluding extraction areas that overlap within a 10-kilometer radius. Consistent with these spillovers biasing our estimates towards zero, the economic magnitude of our main results becomes larger. For example, the coefficient on FCR $\times$ Post 2004 increases from 0.136 in Table 3 of the Manuscript to 0.281 in Table IA3.2. However, excluding overlapping areas makes the difference in estimated treatment effects for countries with strong and weak political institutions statistically insignificant.

\section{Figure IA3.2: Luminosity Effects in Event-Time Excluding Overlapping Extraction Areas}

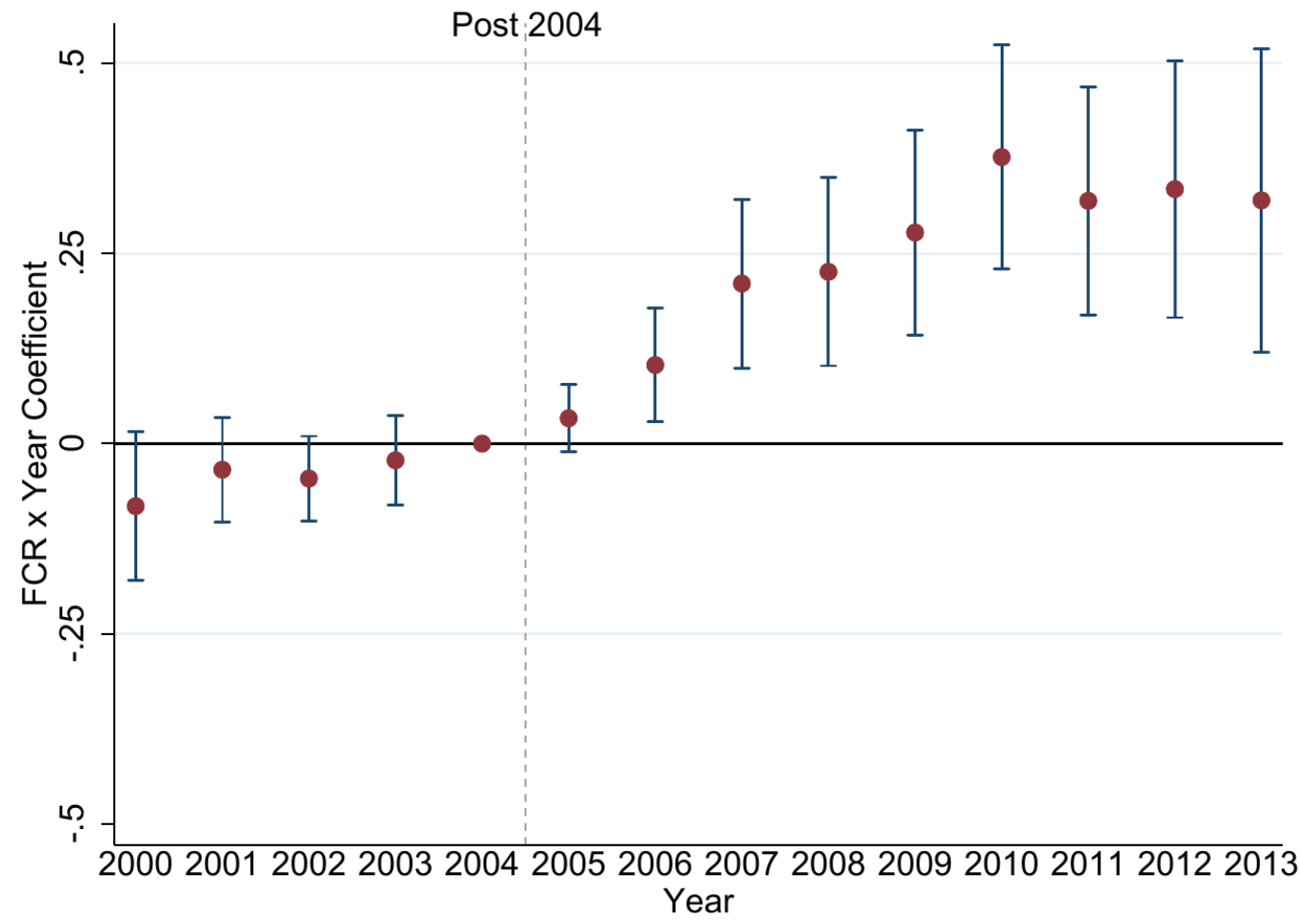

Notes: This figure shows coefficient estimates and 95\% confidence intervals for OLS regressions estimating the effect of the post-2004 increase in FCPA enforcement on nighttime luminosity. We estimate the model from Column (1) of Table 3 in the Manuscript but exclude extraction areas that overlap within a 10-kilometer radius, and replace the $F C R \times$ Post 2004 indicator with separate interactions for each of the years in our sample (except for 2004, which serves as the benchmark). 


\section{Table IA3.2: Luminosity Effects Excluding Overlapping Extraction Areas}

\begin{tabular}{|c|c|c|c|c|c|c|c|}
\hline \multirow{3}{*}{$\begin{array}{l}\text { Dependent Variable: } \\
\text { Ln(Luminosity }(10)+1)\end{array}$} & \multirow{3}{*}{$\begin{array}{c}\frac{\text { Baseline }}{(1)} \\
0-10 \mathrm{~km} \\
\text { Radius }\end{array}$} & \multicolumn{4}{|c|}{ Sensitivity Analyses } & \multicolumn{2}{|c|}{ Role of Institutions } \\
\hline & & $(2)$ & (3) & (4) & (5) & $\begin{array}{c}(6) \\
\text { Weak }\end{array}$ & $\begin{array}{c}(7) \\
\text { Strong }\end{array}$ \\
\hline & & Asinh & $1-10 \mathrm{~km}$ & Within & USJ Non-OECD & Political & $\begin{array}{l}\text { Political } \\
\text { Pnstitutions }\end{array}$ \\
\hline$\frac{\text { Ln(Luminosity }(10)+1)}{F C R \times \text { Post } 2004}$ & $\begin{array}{c}\text { Radius } \\
0.281 \\
(0.065)\end{array}$ & $\begin{array}{c}\text { (Luminosity) } \\
0.372 \\
(0.082)\end{array}$ & $\begin{array}{c}\text { Radius } \\
0.271 \\
(0.064)\end{array}$ & $\begin{array}{c}\text { Region } \times \text { Year } \\
0.302 \\
(0.064)\end{array}$ & $\begin{array}{c}\text { and Non-USJ OECD } \\
0.289 \\
(0.067)\end{array}$ & $\begin{array}{c}\text { Institutions } \\
0.263 \\
(0.088)\end{array}$ & $\begin{array}{c}\text { Institutions } \\
0.348 \\
(0.097)\end{array}$ \\
\hline USJ Non-OECD $\times$ Post 2004 & & & & & $\begin{array}{c}-0.054 \\
(0.091)\end{array}$ & & \\
\hline Non-USJ OECD $\times$ Post 2004 & & & & & $\begin{array}{c}0.060 \\
(0.054) \\
\end{array}$ & & \\
\hline \multicolumn{8}{|l|}{ Difference in Coefficients ( $\mathrm{p}$-value): } \\
\hline $\begin{array}{l}{[\text { FCR-USJ Non-OECD }] \times \text { Post } 2004} \\
{[\text { FCR-Non-USJ OECD }] \times \text { Post } 2004} \\
\text { Weak-Strong Political Institutions }\end{array}$ & & & & & $\begin{array}{l}0.00 \\
0.00\end{array}$ & & \\
\hline Fixed Effects: & & & & & & & \\
\hline Property $\times$ Commodity & Yes & Yes & Yes & Yes & Yes & Yes & Yes \\
\hline Region $\times$ Year & No & No & No & Yes & No & No & No \\
\hline Commodity $\times$ Year & Yes & Yes & Yes & Yes & Yes & Yes & Yes \\
\hline Property-Commodity-Year Observations & 5,194 & 5,194 & 5,194 & 5,194 & 5,194 & 3,234 & 1,596 \\
\hline
\end{tabular}

Notes: This table reports coefficient estimates of OLS regressions estimating the effect of the post-2004 increase in FCPA enforcement on nighttime luminosity. We exclude extraction areas that overlap within a 10-kilometer radius. We describe the sample selection in Internet Appendix Section IA2. The sample is from 2000 to 2013. Conley (1999) standard errors allowing for spatial correlation within a $500 \mathrm{~km}$ radius and for infinite serial correlation are reported in parentheses. Luminosity (10) is the stable light mean unsaturated nighttime luminosity within a $10 \mathrm{~km}$ radius of the respective property. Luminosity in parentheses. Luminosity (10) is the stable light mean unsaturated nighttime luminosity within a $10 \mathrm{~km}$ radius of the respective property. Luminosity $(1-10)$ is the stable light mean unsaturated nighttime luminosity within a $1-10 \mathrm{~km}$ radius of the respective property. FCR is a binary indicator equal to one
if an extraction facility has at least one significant owner (with an ownership stake of $20 \%$ or more) in 2004 who is headquartered, cross-listed, or operates a if an extraction facility has at least one significant owner (with an ownership stake of $20 \%$ or more) in 2004 who is headquartered, cross-listed, or operates a segment in the US and is from a signatory country of the OECD Anti-Bribery Convention. USJ Non-OECD is a binary indicator equal to one if a property
has at least one significant owner (with an ownership stake of $20 \%$ or more) in 2004 who is cross-listed or operates a segment in the US but is not from a signatory country of the OECD Anti-Bribery Convention. Non-USJ OECD is a binary indicator equal to one if a property has at least one significant owner (with an ownership stake of $20 \%$ or more) in 2004 who is from a signatory country of the OECD Anti-Bribery Convention but is not cross-listed and does not operate a segment in the US. Post 2004 is a binary indicator equal to one for years after 2004. 


\section{IA3.3 Keeping only the Main Commodity}

In our baseline sample, $16 \%$ of the mines ( 77 out of 478 mines) produce more than one commodity. If more than one commodity is extracted on the same site, that cell appears in our dataset as a separate observation for each commodity. Our approach implicitly assumes that commodities from the same facility are independent from each other, which they likely are not, given that these commodities are, in most cases, jointly extracted at the same site. The potential interdependence of observations could bias our inferences. As a robustness test, we include each extraction facility only once, based on the commodity with the highest production value. In Figure IA3.3 and Table IA3.3, we find that the estimated treatment effects are generally larger if we keep only the commodity with the highest production value.

\section{Figure IA3.3: Luminosity Effects in Event-Time Keeping Only the Main Commodity}

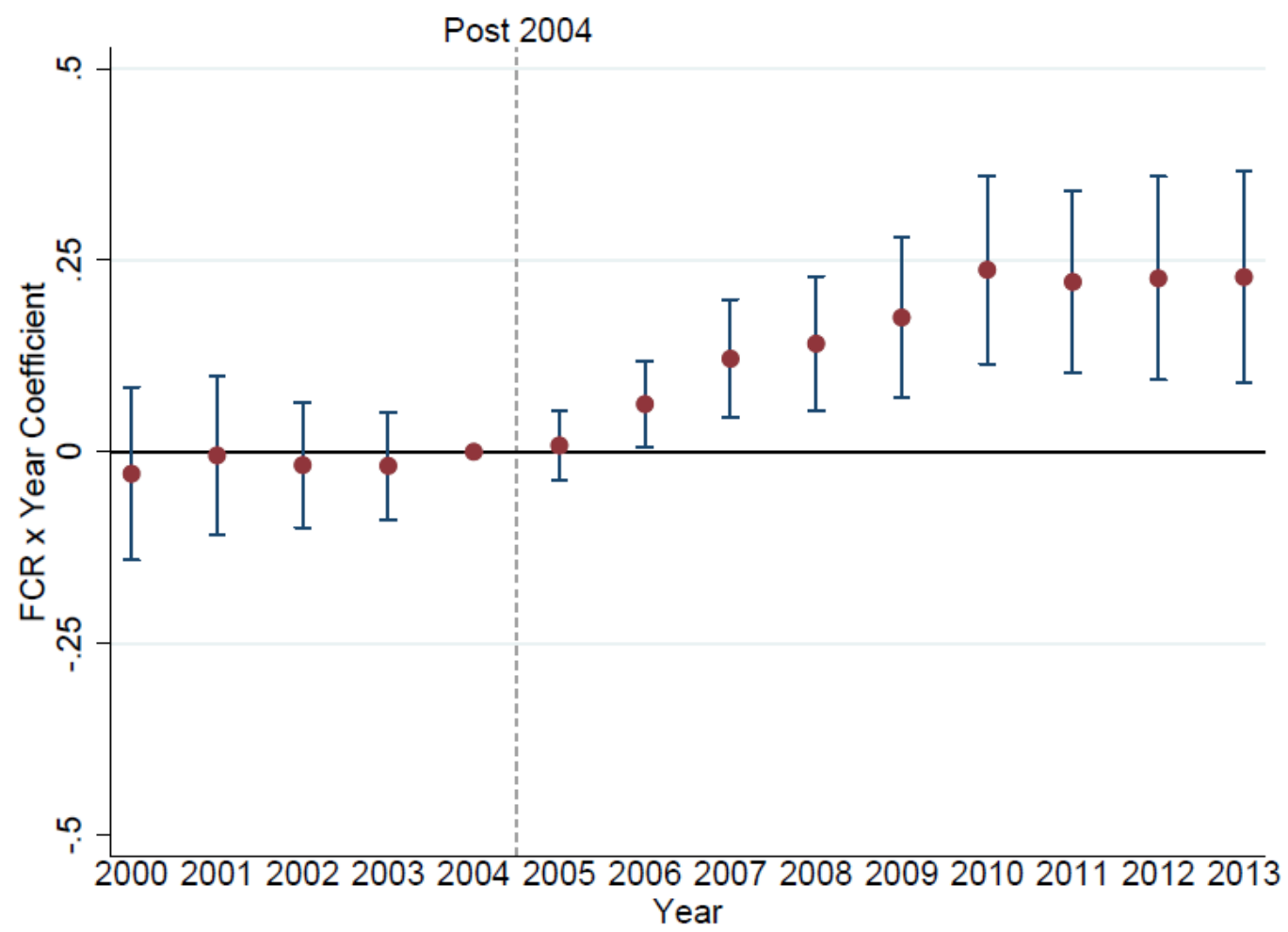

Notes: This figure shows coefficient estimates and 95\% confidence intervals for OLS regressions estimating the effect of the post-2004 increase in FCPA enforcement on nighttime luminosity. We estimate the model from Column (1) of Table 3 in the Manuscript but only keep the main commodity of each mine, and replace the FCR $\times$ Post 2004 indicator with separate interactions for each of the years in our sample (except for 2004, which serves as the benchmark). 
Table IA3.3: Luminosity Effects Keeping Only the Main Commodity

\begin{tabular}{|c|c|c|c|c|c|c|c|}
\hline \multirow[b]{3}{*}{$\begin{array}{l}\text { Dependent Variable: } \\
\text { Ln(Luminosity }(10)+1)\end{array}$} & \multirow{3}{*}{$\begin{array}{c}\frac{\text { Baseline }}{(1)} \\
0-10 \mathrm{~km} \\
\text { Radius }\end{array}$} & \multicolumn{4}{|c|}{ Sensitivity Analyses } & \multicolumn{2}{|c|}{ Role of Institutions } \\
\hline & & $(2)$ & (3) & (4) & $(5)$ & $\begin{array}{c}(6) \\
\text { Weak }\end{array}$ & $\begin{array}{l}(7) \\
\text { Strong }\end{array}$ \\
\hline & & $\begin{array}{c}\text { Asinh } \\
\text { (Luminosity) }\end{array}$ & $\begin{array}{c}1-10 \mathrm{~km} \\
\text { Radius }\end{array}$ & $\begin{array}{l}\text { Within } \\
\text { Region } \times \text { Year }\end{array}$ & $\begin{array}{l}\text { USJ Non-OECD } \\
\text { and Non-USJ OECD }\end{array}$ & $\begin{array}{c}\text { Political } \\
\text { Institutions }\end{array}$ & $\begin{array}{c}\text { Political } \\
\text { Institutions }\end{array}$ \\
\hline$F C R \times$ Post 2004 & $\begin{array}{c}0.172 \\
(0.045)\end{array}$ & $\begin{array}{c}0.226 \\
(0.057)\end{array}$ & $\begin{array}{c}0.167 \\
(0.044)\end{array}$ & $\begin{array}{c}0.183 \\
(0.043)\end{array}$ & $\begin{array}{c}0.158 \\
(0.045)\end{array}$ & $\begin{array}{c}0.311 \\
(0.087)\end{array}$ & $\begin{array}{c}0.091 \\
(0.047)\end{array}$ \\
\hline USJ Non-OECD $\times$ Post 2004 & & & & & $\begin{array}{l}-0.102 \\
(0.046)\end{array}$ & & \\
\hline Non-USJ OECD $\times$ Post 2004 & & & & & $\begin{array}{c}0.052 \\
(0.046) \\
\end{array}$ & & \\
\hline \multicolumn{8}{|l|}{ Difference in Coefficients (p-value): } \\
\hline $\begin{array}{l}{[\text { FCR-USJ Non-OECD }] \times \text { Post } 2004} \\
{[\text { FCR-Non-USJ OECD }] \times \text { Post } 2004} \\
\text { Weak-Strong Political Institutions }\end{array}$ & & & & & $\begin{array}{l}0.00 \\
0.08\end{array}$ & & \\
\hline Fixed Effects: & & & & & & & \\
\hline Property $\times$ Commodity & Yes & Yes & Yes & Yes & Yes & Yes & Yes \\
\hline Region $\times$ Year & No & No & No & Yes & No & No & No \\
\hline Commodity $\times$ Year & Yes & Yes & Yes & Yes & Yes & Yes & Yes \\
\hline Property-Commodity-Year Observations & 8,246 & 8,246 & 8,246 & 8,246 & 8,246 & 3,332 & 4,382 \\
\hline
\end{tabular}

Notes: This table reports coefficient estimates of OLS regressions estimating the effect of the post-2004 increase in FCPA enforcement on nighttime luminosity. We only keep the main commodity of each mine, determined by maximum production value over the sample period. We describe the sample selection in Internet Appendix Section IA2. The sample is from 2000 to 2013. Conley (1999) standard errors allowing for spatial correlation within a 500km radius and for infinite serial correlation are reported in parentheses. Luminosity (10) is the stable light mean unsaturated nighttime luminosity within a $10 \mathrm{~km}$ radius of the respective property, Luminosity $(1-10)$ is the stable light mean unsaturated nighttime luminosity within a $1-10 \mathrm{~km}$ radius of the respective property. $F C R$ is a binary indicator equal to one if an extraction facility has at least one significant owner (with an ownership stake of $20 \%$ or more) in 2004 who is $F C R$ is a binary indicator equal to one if an extraction facility has at least one significant owner (with an ownership stake of $20 \%$ or more) in 2004 who is
headquartered, cross-listed, or operates a segment in the US and is from a signatory country of the OECD Anti-Bribery Convention. USJ Non-OECD is a binary indicator equal to one if a property has at least one significant owner (with an ownership stake of $20 \%$ or more) in 2004 who is cross-listed or operate a segment in the US but is not from a signatory country of the OECD Anti-Bribery Convention. Non-USJ OECD is a binary indicator equal to one if a property has at least one significant owner (with an ownership stake of $20 \%$ or more) in 2004 who is from a signatory country of the OECD Anti-Bribery Convention but is not cross-listed and does not operate a segment in the US. Post 2004 is a binary indicator equal to one for years after 2004. 


\section{IA3.4 Ln(Luminosity) as an Alternative Outcome Variable}

In the Manuscript, our main dependent variable is the natural logarithm of Luminosity plus 1 (we also report results using the inverse hyperbolic sine in sensitivity analyses reported in Tables 3 and 5 of the Manuscript). We include observations with a value of zero because a luminosity value of zero does not necessarily imply an absence of economic activity (Hodler and Raschky 2014). In Figure IA3.4 and Table IA3.4, we drop zero-value observations and use Ln(Luminosity) as the dependent variable. In these alternative specifications, we find that the estimated treatment effects mostly increase in magnitude relative to those reported in the Manuscript.

\section{Figure IA3.4: Luminosity Effects using Ln(Luminosity) as Outcome Variable}

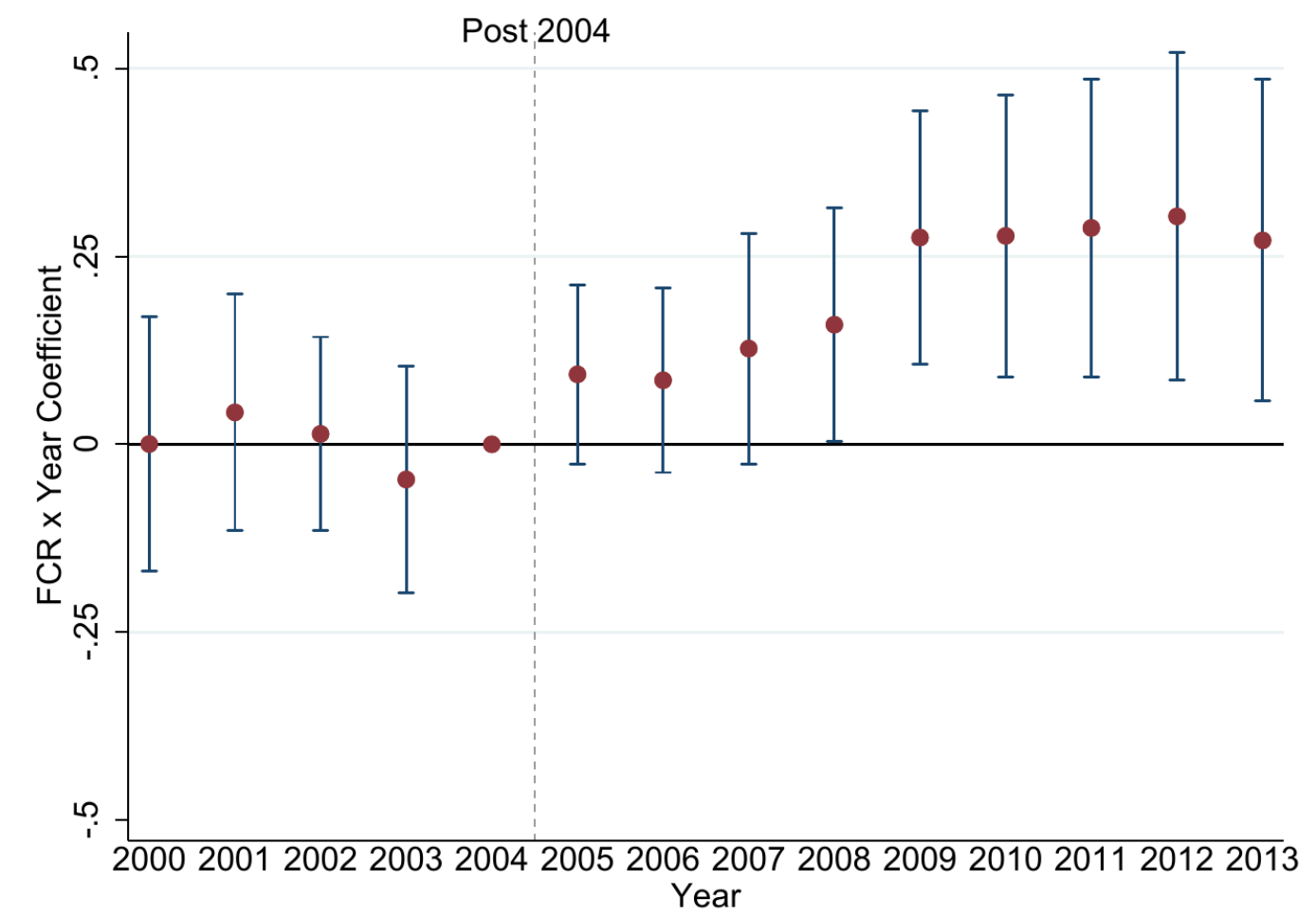

Notes: This figure shows coefficient estimates and 95\% confidence intervals for OLS regressions estimating the effect of the post-2004 increase in FCPA enforcement on nighttime luminosity. We estimate the model from Column (1) of Table 3 in the Manuscript but do not add 1 when log transforming Luminosity, and replace the FCR $\times$ Post 2004 indicator with separate interactions for each of the years in our sample (except for 2004, which serves as the benchmark). 


\section{Table IA3.4: Luminosity Effects using Ln(Luminosity) as Outcome Variable}

\begin{tabular}{|c|c|c|c|c|c|c|c|}
\hline \multirow[b]{3}{*}{$\begin{array}{l}\text { Dependent Variable: } \\
\text { Ln(Luminosity (10)) }\end{array}$} & \multirow{3}{*}{$\begin{array}{c}\frac{\text { Baseline }}{(1)} \\
0-10 \mathrm{~km} \\
\text { Radius }\end{array}$} & \multicolumn{4}{|c|}{ Sensitivity Analyses } & \multicolumn{2}{|c|}{ Role of Institutions } \\
\hline & & (2) & (3) & (4) & (5) & $\begin{array}{c}(6) \\
\text { Weak }\end{array}$ & $\begin{array}{c}(7) \\
\text { Strong }\end{array}$ \\
\hline & & $\begin{array}{c}\text { Asinh } \\
\text { (Luminosity) }\end{array}$ & $\begin{array}{l}1-10 \mathrm{~km} \\
\text { Radius }\end{array}$ & $\begin{array}{c}\text { Within } \\
\text { Region } \times \text { Year }\end{array}$ & $\begin{array}{l}\text { USJ Non-OECD } \\
\text { and Non-USJ OECD }\end{array}$ & $\begin{array}{l}\text { Political } \\
\text { Institutions }\end{array}$ & $\begin{array}{c}\text { Political } \\
\text { Institutions }\end{array}$ \\
\hline FCR $\times$ Post 2004 & $\begin{array}{c}0.207 \\
(0.072)\end{array}$ & $\begin{array}{c}0.138 \\
(0.051)\end{array}$ & $\begin{array}{c}0.202 \\
(0.072)\end{array}$ & $\begin{array}{c}0.207 \\
(0.072)\end{array}$ & $\begin{array}{c}0.216 \\
(0.076)\end{array}$ & $\begin{array}{c}0.532 \\
(0.140)\end{array}$ & $\begin{array}{l}0.064 \\
(0.075)\end{array}$ \\
\hline USJ Non-OECD $\times$ Post 2004 & & & & & $\begin{array}{l}-0.037 \\
(0.067)\end{array}$ & & \\
\hline Non-USJ OECD $\times$ Post 2004 & & & & & $\begin{array}{c}0.157 \\
(0.116)\end{array}$ & & \\
\hline \multicolumn{8}{|l|}{ Difference in Coefficients (p-value): } \\
\hline [FCR-USJ Non-OECD] $\times$ Post 2004 & & & & & 0.00 & & \\
\hline [FCR-Non-USJ OECD] $\times$ Post 2004 & & & & & 0.64 & \multirow{2}{*}{\multicolumn{2}{|c|}{0.02}} \\
\hline Weak-Strong Political Institutions & & & & & & & \\
\hline Fixed Effects: & & & & & & & \\
\hline Property $\times$ Commodity & Yes & Yes & Yes & Yes & Yes & Yes & Yes \\
\hline Region $\times$ Year & No & No & No & Yes & No & No & No \\
\hline Commodity $\times$ Year & Yes & Yes & Yes & Yes & Yes & Yes & Yes \\
\hline Property-Commodity-Year Observations & 8,770 & 8,770 & 8,769 & 8,770 & 8,770 & 2,814 & 5,448 \\
\hline
\end{tabular}

Notes: This table reports coefficient estimates of OLS regressions estimating the effect of the post-2004 increase in FCPA enforcement on nighttime luminosity. We do not add 1 when log transforming Luminosity. We describe the sample selection in Internet Appendix Section IA2. The sample is from 2000 to 2013. Conley (1999) standard errors allowing for spatial correlation within a 500km radius and for infinite serial correlation are reported in parentheses. Luminosity (10) is the stable light mean unsaturated nighttime luminosity within a $10 \mathrm{~km}$ radius of the respective property. Luminosity (1-10) is the stable light mean unsaturated nighttime luminosity within a $1-10 \mathrm{~km}$ radius of the respective property. $F C R$ is a binary indicator equal to one if an extraction facility has at least one significant owner (with an ownership stake of $20 \%$ or more) in 2004 who is headquartered, cross-listed, or operates a segment in the US and is from a signatory country of the OECD Anti-Bribery Convention. USJ Non-OECD is a binary indicator equal to one if a property has at least one significant owner (with an ownership stake of $20 \%$ or more) in 2004 who is cross-listed or operates a segment in the US but is not from a signatory country of the OECD Anti-Bribery Convention. Non-USJ OECD is a binary indicator equal to one if a property has at least one significant owner (with an ownership stake of $20 \%$ or more) in 2004 who is from a signatory country of the OECD Anti-Bribery Convention but is not cross-listed and does not operate a segment in the US. Post 2004 is a binary indicator equal to one for years after 2004 


\section{IA3.5 Placebo Treatment Effects}

In Table 3 Column (5) of the Manuscript, we assess the concern that either being under US jurisdiction or being headquartered in an OECD country is associated with factors (unrelated to foreign corruption regulation) that change around 2005 and explain our results (e.g., a financial market shock). In Table IA3.5, we present all of the results from Table 3 including the two additional USJ Non-OECD $\times$ Post 2004 and Non-USJ OECD $\times$ Post 2004 interaction terms. Across all specifications, we find no evidence of a statistically significant counterfactual treatment effect from being under US jurisdiction or being headquartered in an OECD country absent an increase in the threat of FCPA enforcement. Moreover, the FCR $\times$ Post 2004 coefficient is significantly larger (at the $10 \%$ level or better) than both other coefficients throughout.

Table IA3.5: Placebo Treatment Effects

\begin{tabular}{|c|c|c|c|c|c|c|c|}
\hline \multirow{4}{*}{$\begin{array}{l}\text { Dependent Variable: } \\
\text { Ln(Luminosity }(10)+1)\end{array}$} & \multirow{4}{*}{$\begin{array}{c}\frac{\text { Baseline }}{(1)} \\
0-10 \mathrm{~km} \\
\text { Radius }\end{array}$} & \multicolumn{4}{|c|}{ Sensitivity Analyses } & \multicolumn{2}{|c|}{ Role of Institutions } \\
\hline & & $(2)$ & (3) & (4) & $(5)$ & & $\begin{array}{c}(7) \\
\text { Strong }\end{array}$ \\
\hline & & Asinh & $1-10 \mathrm{~km}$ & Within & USJ Non-OECD & $\begin{array}{l}\text { Weak } \\
\text { Political }\end{array}$ & Political \\
\hline & & (Luminosity) & Radius & Region $\times$ Year & and Non-USJ OECD & Institutions & Institutions \\
\hline FCR $\times$ Post 2004 & $\begin{array}{c}0.134 \\
(0.041)\end{array}$ & $\begin{array}{c}0.184 \\
(0.053)\end{array}$ & $\begin{array}{c}0.128 \\
(0.040)\end{array}$ & $\begin{array}{c}0.149 \\
(0.040)\end{array}$ & $\begin{array}{c}0.134 \\
(0.041)\end{array}$ & $\begin{array}{c}0.283 \\
(0.079)\end{array}$ & $\begin{array}{c}0.047 \\
(0.045)\end{array}$ \\
\hline USJ Non-OECD $\times$ Post 2004 & $\begin{array}{l}-0.030 \\
(0.040)\end{array}$ & $\begin{array}{l}-0.037 \\
(0.050)\end{array}$ & $\begin{array}{l}-0.029 \\
(0.040)\end{array}$ & $\begin{array}{l}0.006 \\
(0.037)\end{array}$ & $\begin{array}{l}-0.030 \\
(0.040)\end{array}$ & $\begin{array}{l}-0.065 \\
(0.130)\end{array}$ & $\begin{array}{c}0.001 \\
(0.037)\end{array}$ \\
\hline Non-USJ OECD $\times$ Post 2004 & $\begin{array}{c}0.043 \\
(0.039) \\
\end{array}$ & $\begin{array}{c}0.064 \\
(0.050) \\
\end{array}$ & $\begin{array}{c}0.039 \\
(0.038)\end{array}$ & $\begin{array}{c}0.051 \\
(0.037)\end{array}$ & $\begin{array}{c}0.043 \\
(0.039) \\
\end{array}$ & $\begin{array}{c}0.006 \\
(0.088)\end{array}$ & $\begin{array}{c}0.046 \\
(0.045) \\
\end{array}$ \\
\hline $\begin{array}{l}\text { Difference in Coefficients (p-value): } \\
{[\text { FCR-USJ Non-OECD }] \times \text { Post } 2004} \\
{[\text { FCR-Non-USJ OECD }] \times \text { Post } 2004} \\
\text { Weak-Strong Political Institutions }\end{array}$ & $\begin{array}{l}0.00 \\
0.08\end{array}$ & $\begin{array}{l}0.00 \\
0.07\end{array}$ & $\begin{array}{l}0.00 \\
0.08\end{array}$ & $\begin{array}{l}0.00 \\
0.05\end{array}$ & $\begin{array}{l}0.00 \\
0.08\end{array}$ & $\begin{array}{l}0.01 \\
0.00\end{array}$ & $\begin{array}{l}0.36 \\
0.98\end{array}$ \\
\hline $\begin{array}{l}\text { Fixed Effects: } \\
\text { Property } \times \text { Commodity } \\
\text { Region } \times \text { Year } \\
\text { Commodity } \times \text { Year } \\
\text { Property-Commodity-Year Observations }\end{array}$ & $\begin{array}{c}\text { Yes } \\
\text { No } \\
\text { Yes } \\
10,318\end{array}$ & $\begin{array}{l}\text { Yes } \\
\text { No } \\
\text { Yes } \\
10,318\end{array}$ & $\begin{array}{l}\text { Yes } \\
\text { No } \\
\text { Yes } \\
10,318\end{array}$ & $\begin{array}{c}\text { Yes } \\
\text { Yes } \\
\text { Yes } \\
10,318\end{array}$ & $\begin{array}{l}\text { Yes } \\
\text { No } \\
\text { Yes } \\
10,318\end{array}$ & $\begin{array}{l}\text { Yes } \\
\text { No } \\
\text { Yes } \\
3,836\end{array}$ & $\begin{array}{l}\text { Yes } \\
\text { No } \\
\text { Yes } \\
5,824\end{array}$ \\
\hline $\begin{array}{l}\text { Notes: This table reports coefficient estimat } \\
\text { controlling for USJ Non-OECD and Non- } \\
2000 \text { to } 2013 \text {. Conley (1999) standard er } \\
\text { parentheses. Luminosity (10) is the stab } \\
\text { (1-10) is the stable light mean unsaturated } \\
\text { if an extraction facility has at least one sign } \\
\text { segment in the US and is from a signatory } \\
\text { has at least one significant owner (with an } \\
\text { signatory country of the OECD Anti-Briber } \\
\text { (with an ownership stake of } 20 \% \text { or more) } \\
\text { not operate a segment in the US. Post } 200\end{array}$ & $\begin{array}{l}\text { s of OLS r } \\
S J O E C D \\
\text { ors allowin } \\
\text { light mea } \\
\text { ighttime } 1 \\
\text { ficant own } \\
\text { puntry of } \mathrm{t} \\
\text { wnership } \\
\text { Conventic } \\
2004 \text { whe }\end{array}$ & $\begin{array}{l}\text { ressions estima } \\
\text { roperties. We } \\
\text { for spatial co } \\
\text { unsaturated n } \\
\text { minosity withi } \\
\text { (with an owne } \\
\text { OECD Anti- } \\
\text { ake of } 20 \% \text { or } \\
\text { Non-USJ O } \\
\text { is from a signa } \\
\text { indicator equa }\end{array}$ & $\begin{array}{l}\text { ing the eff } \\
\text { lescribe th } \\
\text { relation w } \\
\text { ghttime lu } \\
\text { a } 1-10 \mathrm{~km} \\
\text { ship stake } \\
\text { ribery Con } \\
\text { nore) in } 20 \\
C D \text { is a bi } \\
\text { ory countr } \\
\text { to one for }\end{array}$ & $\begin{array}{l}\text { of the post- } 200 \\
\text { ample selection } \\
\text { in a } 500 \mathrm{~km} \mathrm{rac} \\
\text { nosity within a } \\
\text { dius of the resp } \\
20 \% \text { or more) i } \\
\text { ntion. USJ Non } \\
\text { who is cross-lis } \\
\text { ry indicator equ } \\
\text { of the OECD A } \\
\text { ears after } 2004\end{array}$ & $\begin{array}{l}\text { ncrease in FCPA enforc } \\
\text { Internet Appendix Se } \\
\text { 1s and for infinite seri } \\
0 \mathrm{~km} \text { radius of the res } \\
\text { tive property. FCR is } \\
2004 \text { who is headquart } \\
D E C D \text { is a binary indic } \\
\mathrm{d} \text { or operates a segme } \\
\text { to one if a property ha } \\
\text { i-Bribery Convention }\end{array}$ & $\begin{array}{l}\text { ment on night } \\
\text { tion IA2. The } \\
\text { l correlation } \\
\text { ective proper } \\
\text { binary indica } \\
\text { red, cross-liste } \\
\text { ator equal to o } \\
\text { in the US bi } \\
\text { at least one s } \\
\text { at is not cross }\end{array}$ & $\begin{array}{l}\text { me luminosity } \\
\text { ample is fron } \\
\text { e reported in } \\
\text { Luminosit } \\
\text { r equal to on } \\
\text { or operates } \\
\text { if a property } \\
\text { is not from } \\
\text { nificant owne } \\
\text { sted and doe }\end{array}$ \\
\hline
\end{tabular}




\section{IA3.6 Controlling for Economic Conditions in Headquarter Countries}

Our classification of treated facilities is partly determined by whether the facility's parent company (i.e., the ultimate owner of the facility) is headquartered in a country that is a member of the Organization for Economic Co-operation and Development (OECD). OECD membership requires a commitment to democracy and a market economy, implying that OECD countries differ from non-OECD countries along many dimensions. Perhaps the most concerning difference for our research design is the fact that OECD countries' macroeconomic fluctuations are highly correlated (and almost certainly more correlated than those of non-OECD countries). In our difference-indifferences design, the concern is that our estimated treatment effect of foreign corruption regulation could be biased if 1) an economic shock occurred around 2005 (i.e., concurrent to the FCPA enforcement increase), 2) this shock differentially affected OECD and non-OECD countries, and 3) macroeconomic fluctuations in headquarter countries impact how firms operate their extraction facilities in Africa.

One way to address this issue is to control for some observable macroeconomic conditions in the parent country and assess how those controls impact our estimated treatment effects. This approach directly addresses selection on the observables we control for and, to the extent observable and unobservable factors are correlated, provides a way to gauge the magnitude of any potential unobservable confound (Altonji et al., 2005). That is, we first reproduce the main results without any control variables for the sample where the control variables are available and then add the control variables and assess the change in the magnitude of the estimated treatment effect.

We select variables that are likely highly associated with macroeconomic shocks that could potentially provide alternative explanations for our results, particularly factors that may affect firms' ability to expand their operations abroad. We focus on GDP growth and unemployment rates. GDP growth is likely associated with financial shocks and unemployment levels are likely associated with labor market constraints (i.e., a higher labor supply increases a firm's ability to expand operations).

Table IA3.6 Panel A mirrors Table 3 of the Manuscript but conditions the sample on non-missing macroeconomic controls. The results are virtually identical to those reported in the Manuscript. In Table IA3.6 Panel B, we use the same regression sample but include the unemployment rate and GDP growth of the owner's headquarter country as control variables (stand alone and interacted with Post 2004). The coefficients on the control variables have the expected signs (GDP growth and higher unemployment increase the ability to expand abroad). The estimated treatment effects attenuate slightly in Columns (1) to (3) but, in the more stringent specifications in Columns (4) and (5), they become slightly stronger. The difference in treatment effects between countries with weak and strong political institutions in Columns (6) and (7) is virtually unchanged.

Overall, these results suggest that observable, and correlated unobservable, macroeconomic factors in the headquarter country of a facility's owner are unlikely to explain our results. 
Table IA3.6: Controlling for Economic Conditions in Headquarter Countries

Panel A: Without Macroeconomic Controls

\begin{tabular}{|c|c|c|c|c|c|c|c|}
\hline \multirow[b]{3}{*}{$\begin{array}{l}\text { Dependent Variable: } \\
\text { Ln(Luminosity }(10)+1)\end{array}$} & \multirow{3}{*}{$\begin{array}{c}\frac{\text { Baseline }}{(1)} \\
0-10 \mathrm{~km} \\
\text { Radius }\end{array}$} & \multicolumn{4}{|c|}{ Sensitivity Analyses } & \multicolumn{2}{|c|}{ Role of Institutions } \\
\hline & & $(2)$ & (3) & (4) & (5) & $\begin{array}{c}(6) \\
\text { Weak }\end{array}$ & $\begin{array}{c}(7) \\
\text { Strong }\end{array}$ \\
\hline & & $\begin{array}{c}\text { Asinh } \\
\text { (Luminosity) }\end{array}$ & $\begin{array}{l}1-10 \mathrm{~km} \\
\text { Radius }\end{array}$ & $\begin{array}{l}\text { Within } \\
\text { Region } \times \text { Year }\end{array}$ & $\begin{array}{l}\text { USJ Non-OECD } \\
\text { and Non-USJ OECD }\end{array}$ & $\begin{array}{l}\text { Political } \\
\text { Institutions }\end{array}$ & $\begin{array}{l}\text { Political } \\
\text { Institutions }\end{array}$ \\
\hline FCR $\times$ Post 2004 & $\begin{array}{c}0.139 \\
(0.040)\end{array}$ & $\begin{array}{c}0.189 \\
(0.052)\end{array}$ & $\begin{array}{c}0.133 \\
(0.039)\end{array}$ & $\begin{array}{c}0.142 \\
(0.039)\end{array}$ & $\begin{array}{c}0.138 \\
(0.041)\end{array}$ & $\begin{array}{c}0.281 \\
(0.075)\end{array}$ & $\begin{array}{l}0.047 \\
(0.043)\end{array}$ \\
\hline USJ Non-OECD $\times$ Post 2004 & & & & & $\begin{array}{l}-0.036 \\
(0.043)\end{array}$ & & \\
\hline Non-USJ OECD $\times$ Post 2004 & & & & & $\begin{array}{c}0.046 \\
(0.039)\end{array}$ & & \\
\hline \multicolumn{8}{|l|}{ Difference in Coefficients (p-value): } \\
\hline $\begin{array}{l}{[\text { FCR-USJ Non-OECD }] \times \text { Post } 2004} \\
{[\text { FCR-Non-USJ OECD }] \times \text { Post } 2004} \\
\text { Weak-Strong Political Institutions }\end{array}$ & & & & & $\begin{array}{l}0.00 \\
0.08\end{array}$ & & \\
\hline Fixed Effects: & & & & & & & \\
\hline Property $\times$ Commodity & Yes & Yes & Yes & Yes & Yes & Yes & Yes \\
\hline Region $\times$ Year & No & No & No & Yes & No & No & No \\
\hline Commodity $\times$ Year & Yes & Yes & Yes & Yes & Yes & Yes & Yes \\
\hline Property-Commodity-Year Observations & 9,960 & 9,960 & 9,960 & 9,960 & 9,960 & 3,744 & 5,628 \\
\hline
\end{tabular}

\section{Panel B: With Macroeconomic Controls}

\begin{tabular}{|c|c|c|c|c|c|c|c|}
\hline \multirow[b]{3}{*}{$\begin{array}{l}\text { Dependent Variable: } \\
\text { Ln(Luminosity }(10)+1)\end{array}$} & \multirow{3}{*}{$\begin{array}{c}\frac{\text { Baseline }}{(1)} \\
0-10 \mathrm{~km} \\
\text { Radius }\end{array}$} & \multicolumn{4}{|c|}{ Sensitivity Analyses } & \multicolumn{2}{|c|}{ Role of Institutions } \\
\hline & & $(2)$ & (3) & (4) & (5) & $\begin{array}{c}(6) \\
\text { Weak }\end{array}$ & $\begin{array}{c}(7) \\
\text { Strong }\end{array}$ \\
\hline & & $\begin{array}{c}\text { Asinh } \\
\text { (Luminosity) }\end{array}$ & $\begin{array}{l}1-10 \mathrm{~km} \\
\text { Radius }\end{array}$ & $\begin{array}{c}\text { Within } \\
\text { Region } \times \text { Year }\end{array}$ & $\begin{array}{l}\text { USJ Non-OECD } \\
\text { and Non-USJ OECD }\end{array}$ & $\begin{array}{c}\text { Political } \\
\text { Institutions }\end{array}$ & $\begin{array}{l}\text { Political } \\
\text { Institutions }\end{array}$ \\
\hline FCR $\times$ Post 2004 & $\begin{array}{c}0.131 \\
(0.044)\end{array}$ & $\begin{array}{c}0.173 \\
(0.056)\end{array}$ & $\begin{array}{c}0.125 \\
(0.043)\end{array}$ & $\begin{array}{c}0.164 \\
(0.043)\end{array}$ & $\begin{array}{c}0.153 \\
(0.048)\end{array}$ & $\begin{array}{l}0.281 \\
(0.075)\end{array}$ & $\begin{array}{l}0.031 \\
(0.055)\end{array}$ \\
\hline USJ Non-OECD $\times$ Post 2004 & & & & & $\begin{array}{l}-0.045 \\
(0.049)\end{array}$ & & \\
\hline Non-USJ OECD $\times$ Post 2004 & & & & & $\begin{array}{c}0.061 \\
(0.048)\end{array}$ & & \\
\hline \multicolumn{8}{|l|}{ Owner Country Controls: } \\
\hline GDP Growth & $\begin{array}{c}0.000 \\
(0.003)\end{array}$ & $\begin{array}{c}0.000 \\
(0.004)\end{array}$ & $\begin{array}{c}0.000 \\
(0.003)\end{array}$ & $\begin{array}{l}-0.000 \\
(0.003)\end{array}$ & $\begin{array}{c}0.000 \\
(0.003)\end{array}$ & $\begin{array}{l}-0.003 \\
(0.004)\end{array}$ & $\begin{array}{l}0.006 \\
(0.004)\end{array}$ \\
\hline GDP Growth $\times$ Post 2004 & $\begin{array}{c}0.001 \\
(0.003)\end{array}$ & $\begin{array}{c}0.001 \\
(0.004)\end{array}$ & $\begin{array}{c}0.001 \\
(0.003)\end{array}$ & $\begin{array}{c}0.001 \\
(0.003)\end{array}$ & $\begin{array}{c}0.000 \\
(0.003)\end{array}$ & $\begin{array}{c}0.003 \\
(0.004)\end{array}$ & $\begin{array}{l}-0.000 \\
(0.006)\end{array}$ \\
\hline Unemployment Rate & $\begin{array}{c}0.009 \\
(0.004)\end{array}$ & $\begin{array}{c}0.013 \\
(0.005)\end{array}$ & $\begin{array}{c}0.009 \\
(0.004)\end{array}$ & $\begin{array}{c}0.005 \\
(0.004)\end{array}$ & $\begin{array}{c}0.007 \\
(0.004)\end{array}$ & $\begin{array}{c}0.005 \\
(0.006)\end{array}$ & $\begin{array}{c}0.006 \\
(0.004)\end{array}$ \\
\hline Unemployment Rate $\times$ Post 2004 & $\begin{array}{c}0.002 \\
(0.002) \\
\end{array}$ & $\begin{array}{c}0.003 \\
(0.002) \\
\end{array}$ & $\begin{array}{c}0.002 \\
(0.002) \\
\end{array}$ & $\begin{array}{c}0.004 \\
(0.002) \\
\end{array}$ & $\begin{array}{c}0.004 \\
(0.002) \\
\end{array}$ & $\begin{array}{c}0.007 \\
(0.004) \\
\end{array}$ & $\begin{array}{c}0.001 \\
(0.002) \\
\end{array}$ \\
\hline \multicolumn{8}{|l|}{ Difference in Coefficients (p-value): } \\
\hline $\begin{array}{l}{[\text { FCR-USJ Non-OECD }] \times \text { Post } 2004} \\
{[\text { FCR-Non-USJ OECD }] \times \text { Post } 2004} \\
\text { Weak-Strong Political Institutions }\end{array}$ & & & & & $\begin{array}{l}0.01 \\
0.08\end{array}$ & & \\
\hline Fixed Effects: & & & & & & & \\
\hline Property $\times$ Commodity & Yes & Yes & Yes & Yes & Yes & Yes & Yes \\
\hline Region $\times$ Year & No & No & No & Yes & No & No & No \\
\hline Commodity $\times$ Year & Yes & Yes & Yes & Yes & Yes & Yes & Yes \\
\hline Property-Commodity-Year Observations & 9,960 & 9,960 & 9,960 & 9,960 & 9,960 & 3,744 & 5,628 \\
\hline
\end{tabular}

Notes: This table reports coefficient estimates of OLS regressions estimating the effect of the post-2004 increase in FCPA enforcement on nighttime luminosity. We restrict the sample to extraction facilities whose main owner country in 2004 has non-missing GDP growth data. We describe the sample selection in Internet Appendix Section IA2. The sample is from 2000 to 2013. Conley (1999) standard errors allowing for spatial correlation within a 500km radius and for infinite serial correlation are reported in parentheses. Luminosity (10) is the stable light mean unsaturated nighttime luminosity within a $10 \mathrm{~km}$ radius of the respective property. Luminosity $(1-10)$ is the stable light mean unsaturated nighttime luminosity within a $1-10 \mathrm{~km}$ radius of the respective property. FCR is a binary indicator equal to one if an extraction facility has at least one significant owner (with an ownership stake of $20 \%$ or more) in 2004 who is headquartered, cross-listed, or operates a segment in the US and is from a signatory country of the OECD Anti-Bribery Convention. USJ Non-OECD is a binary indicator equal to one if a property has at least one significant owner (with an ownership stake of $20 \%$ or more) in 2004 who is cross-listed or operates a segment in the US but is not from a signatory country of the OECD Anti-Bribery Convention. Non-USJ OECD is a binary indicator equal operates a Anti-Bribery Couvention but is not ross-listed a ows. Post 2004 is a b GDP Growth is the annual percentage growth rate of real GDP per capita of the property's main owner country in 2004 . Unemployment Rate is the annual rate of unemployment (in percentage points) of the property's main owner country in 2004. 


\section{Section IA4: Changes in the Size of the Extraction Sector}

In Section 3.3 of the Manuscript, we discuss how the positive association between foreign corruption regulation and local economic development could be explained by a decrease in activity in the extraction sector. To assess this possibility, we compare changes in mining-related employment around the FCPA enforcement increase in mining cells with and without a controlling owner subject to the FCPA by estimating the following OLS regression:

$$
\text { Fraction of Miners } \text { c }, t_{1}=\beta_{1} F C R_{i} \times \text { Post } 2004_{t}+\text { Fixed Effects }+\varepsilon_{c, t}
$$

Fraction of Miners $c$, is the proportion of workers in cell $c$ and survey round $t$ that indicated being a miner based on the Afrobarometer survey question: "What is your main occupation?" The other variables and fixed effects are identical to Eq. (1) in the Manuscript (except that the time dimension in this analysis is the respective survey round instead of the year). Unfortunately, the analysis is constrained by two data limitations. First, Afrobarometer does not ask questions about miningrelated employment after survey round 3 in 2005/2006. Second, oil and gas-related employment is not recorded by Afrobarometer, which is why we focus on mines in this analysis.

In Table IA4, we report the results from estimating Eq. (IA.1). The $F C R \times$ Post 2004 coefficients are close to zero and statistically insignificant whether or not we additionally control for Region $\times$ Round fixed effects (Column 2) or not (Column 1).

\section{Table IA4: Effect of Foreign Corruption Regulation on Mining Occupation}

\begin{tabular}{lcc}
\hline \hline & $(1)$ & $(2)$ \\
Dependent Variable: Fraction of Miners & Without & With \\
& Region $\times$ Round FE & Region $\times$ Round FE \\
\hline FCR $\times$ Post 2004 & -0.000 & -0.006 \\
& $(0.012$ & $(0.009)$ \\
\hline Fixed Effects: & Yes & Yes \\
Property $\times$ Commodity & No & Yes \\
Region $\times$ Round & Yes & Yes \\
Commodity $\times$ Round & 1,193 & 1,193 \\
\hline Property-Commodity-Round Observations & & \\
\hline
\end{tabular}

Notes: This table reports coefficient estimates of OLS regressions estimating the effect of the post-2004 increase in FCPA enforcement on mining-related employment in mining areas. Conley (1999) standard errors allowing for spatial correlation within a $500 \mathrm{~km}$ radius and for infinite serial correlation are reported in parentheses. Fraction of Miners is the fraction of workers that indicated their main occupation as Miner based on the Afrobarometer survey question: What is your main occupation? (If unemployed, retired, or disabled, what was your last main occupation?). FCR is a binary indicator equal to one if an extraction facility has at least one significant owner (with an ownership stake of $20 \%$ or more) in 2004 who is headquartered, cross-listed, or operates a segment in the US and is from a signatory country of the OECD Anti-Bribery Convention. Post 2004 is a binary indicator equal to one for years after 2004.

The plot of the estimated treatment effect by year in Figure IA4 is consistent with the null result in Table IA4. That is, we find a flat treatment pattern throughout the limited sample period- the coefficient estimates for survey rounds 1 and 3 are almost identical and statistically indistinguishable from the benchmark period (round 2).

Overall, these results are inconsistent with a decline in activity in the extraction sector explaining the increase in economic development. 


\section{Figure IA4: Mining Occupation Effects in Event-Time}

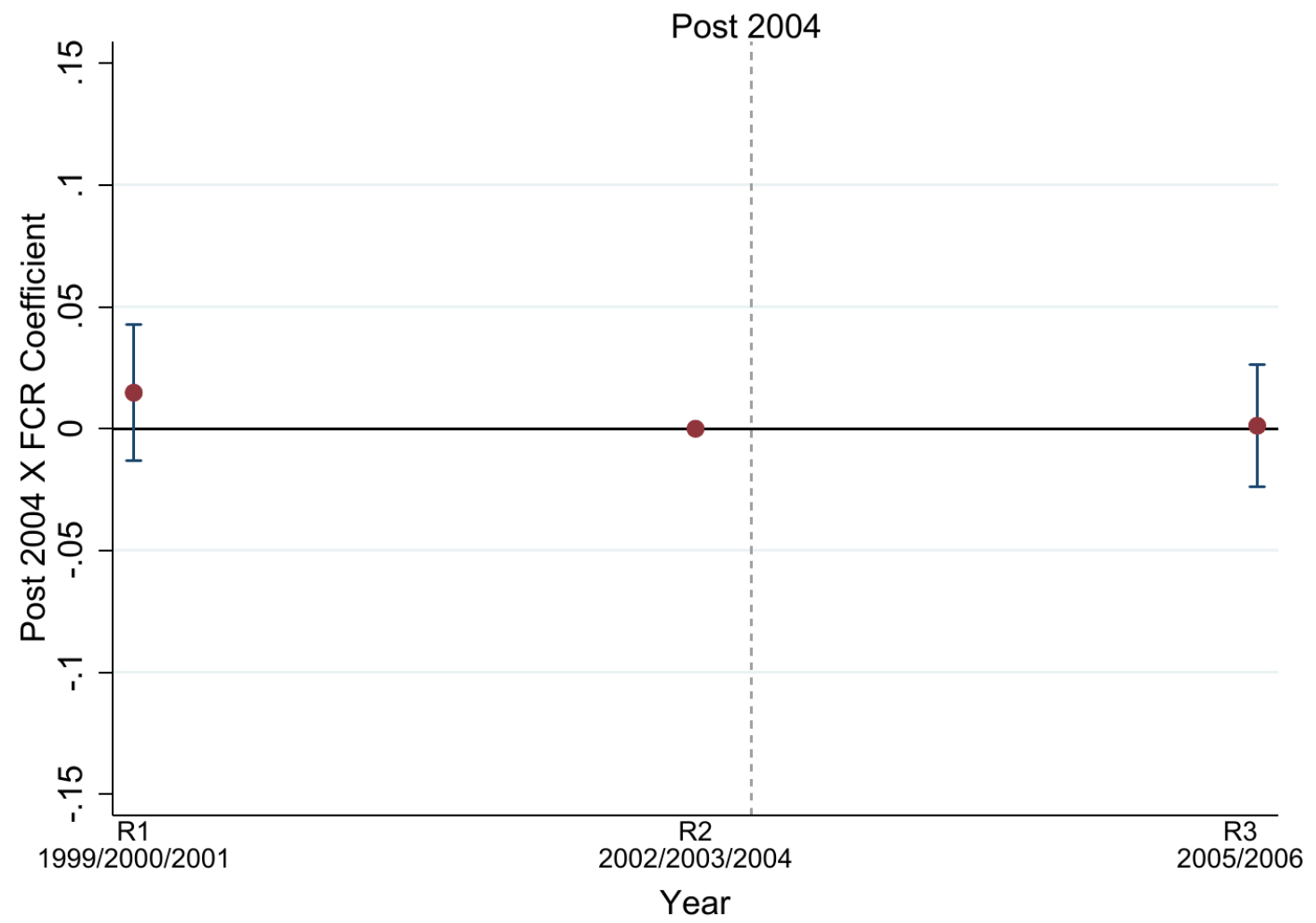

Notes: This figure shows coefficient estimates and 95\% confidence intervals for OLS regressions estimating the effect of the post-2004 increase in FCPA enforcement on mining-related employment in mining areas. We estimate the model from Column (2) of Table IA4 but replace the FCR $\times$ Post 2004 indicator with separate interactions for each survey round in our sample (except for round 2, which serves as the benchmark). 


\section{Section IA5: Supplementary Tests for Analyses of Changes in the Extraction Sector}

\section{IA5.1 Composition of Afrobarometer Survey Sample}

In Table IA5.1, we provide a breakdown of the Afrobarometer data by country and survey round. Overall, our sample covers the responses of 56,276 African citizens in 4,531 villages across 31 African countries and 6 survey rounds between 1999 and 2015. Individual survey locations are widely dispersed across Africa. The countries that contribute the most observations are South Africa (13.7\%), Zimbabwe (13.3\%), Ghana (9.7\%), Botswana (7.7\%), and Lesotho (6.9\%). Data coverage has improved over time-rounds 1 to 4 of the Afrobarometer include fewer countries and respondents (18 countries; $47.4 \%$ of observations) than rounds 5 and 6 (31 countries; $52.6 \%$ ). Nevertheless, the first two survey rounds conducted before the FCPA enforcement increase (i.e., before 2005) cover 15 countries and 13,132 observations (23.5\%), providing us with preperiod data for our difference-in-differences regressions in Table 4 of the Manuscript.

Table IA5.1: Survey Respondents in Extraction Areas by Country and Round

\begin{tabular}{|c|c|c|c|c|c|c|c|}
\hline & $\begin{array}{c}\text { All } \\
\text { Respondents }\end{array}$ & $\begin{array}{c}\text { Round 1 } \\
1999 / 2000 / 2001\end{array}$ & $\begin{array}{c}\text { Round } 2 \\
2002 / 2003 / 2004\end{array}$ & $\begin{array}{l}\text { Round 3 } \\
2005 / 2006\end{array}$ & $\begin{array}{c}\text { Round } 4 \\
2008 / 2009\end{array}$ & $\begin{array}{c}\text { Round 5 } \\
2011 / 2012 / 2013\end{array}$ & $\begin{array}{c}\text { Round } 6 \\
2014 / 2015\end{array}$ \\
\hline Algeria & 321 & & . & ( & . & 191 & 130 \\
\hline Botswana & 4,315 & 721 & 804 & 902 & 913 & 495 & 480 \\
\hline Burkina Faso & 2,035 & . & . & . & 590 & 635 & 810 \\
\hline Burundi & 509 & . & . & . & . & 230 & 279 \\
\hline Egypt & 644 & . & . & . & . & 400 & 244 \\
\hline Gabon & 277 & . & . & . & . & . & 277 \\
\hline Ghana & 5,449 & 1,189 & 569 & 514 & 612 & 1,339 & 1,226 \\
\hline Guinea & 1,621 & . & . & . & . & 808 & 813 \\
\hline Ivory Coast & 786 & . & . & . & . & 329 & 457 \\
\hline Kenya & 583 & . & 178 & 71 & 63 & 121 & 150 \\
\hline Lesotho & 3,907 & 576 & 661 & 498 & 694 & 692 & 786 \\
\hline Liberia & 856 & . & . & . & 277 & 273 & 306 \\
\hline Madagascar & 618 & . & . & 145 & 101 & 119 & 253 \\
\hline Malawi & 74 & 15 & 14 & 14 & 3 & 13 & 15 \\
\hline Mali & 1,390 & 335 & 231 & 195 & 169 & 230 & 230 \\
\hline Morocco & 418 & . & . & . & . & 224 & 194 \\
\hline Mozambique & 829 & . & 71 & 141 & 161 & 201 & 255 \\
\hline Namibia & 1,770 & 275 & 261 & 281 & 297 & 329 & 327 \\
\hline Niger & 310 & . & . & . & . & 193 & 117 \\
\hline Nigeria & 1,991 & 427 & 366 & 409 & 244 & 275 & 270 \\
\hline Senegal & 89 & . & 10 & 16 & 22 & 12 & 29 \\
\hline Sierra Leone & 2,147 & . & . & . & . & 1,143 & 1,004 \\
\hline South Africa & 7,709 & 1,112 & 1,253 & 1,286 & 1,282 & 1,316 & 1,460 \\
\hline Sudan & 43 & . & . & . & . & 15 & 28 \\
\hline Swaziland & 2,123 & . & . & . & . & 1,036 & 1,087 \\
\hline Tanzania & 2,170 & 525 & 188 & 162 & 272 & 472 & 551 \\
\hline Togo & 152 & . & . & . & . & 81 & 71 \\
\hline Tunisia & 796 & . & . & . & . & 400 & 396 \\
\hline Uganda & 2,345 & 353 & 484 & 352 & 366 & 408 & 382 \\
\hline Zambia & 2,514 & 346 & 490 & 387 & 421 & 404 & 466 \\
\hline Zimbabwe & 7,485 & 874 & 804 & 837 & 849 & 2,214 & 1,907 \\
\hline Total & 56,276 & 6,748 & 6,384 & 6,210 & 7,336 & 14,598 & 15,000 \\
\hline
\end{tabular}

Notes: This table presents the number of Afrobarometer survey respondents by country and survey round. 


\section{IA5.2 Commodity Price Variation}

In Section 4.2 of the Manuscript, we use variation in world commodity prices as an instrument for production quantities to examine whether foreign corruption regulation increases the contribution of extraction activities to local economic development. For our instrument to be effective, we need sufficient variation in world prices among commodities. If changes in commodity prices are highly correlated, the variability of our price instrument would be limited.

To examine how highly commodity prices are correlated, we plot the price paths of the 18 commodities in our sample over the sample period (note: there are no world prices for coal and gas, which is why there are only 18 commodities in Table 5 but 20 commodities in Table 3 of the Manuscript). We index all commodities to their respective price level in 2004, the year before the FCPA enforcement increase. In Figure IA5.2, we find that there is significant variation in world prices across commodities over time. The graphical evidence suggests that, in terms of variability, world commodity prices are a suitable instrument for local production quantities. Note that the large drop in price of tantalum from 2000 to 2001 is not a data error and can likely be explained by capacitor producers switching to alternative commodities in 2001 (Mancheri et al. 2018). The inclusion of tantalum does not affect our estimates (see Section IA3.1).

Figure IA5.2: Commodity Prices Over Time
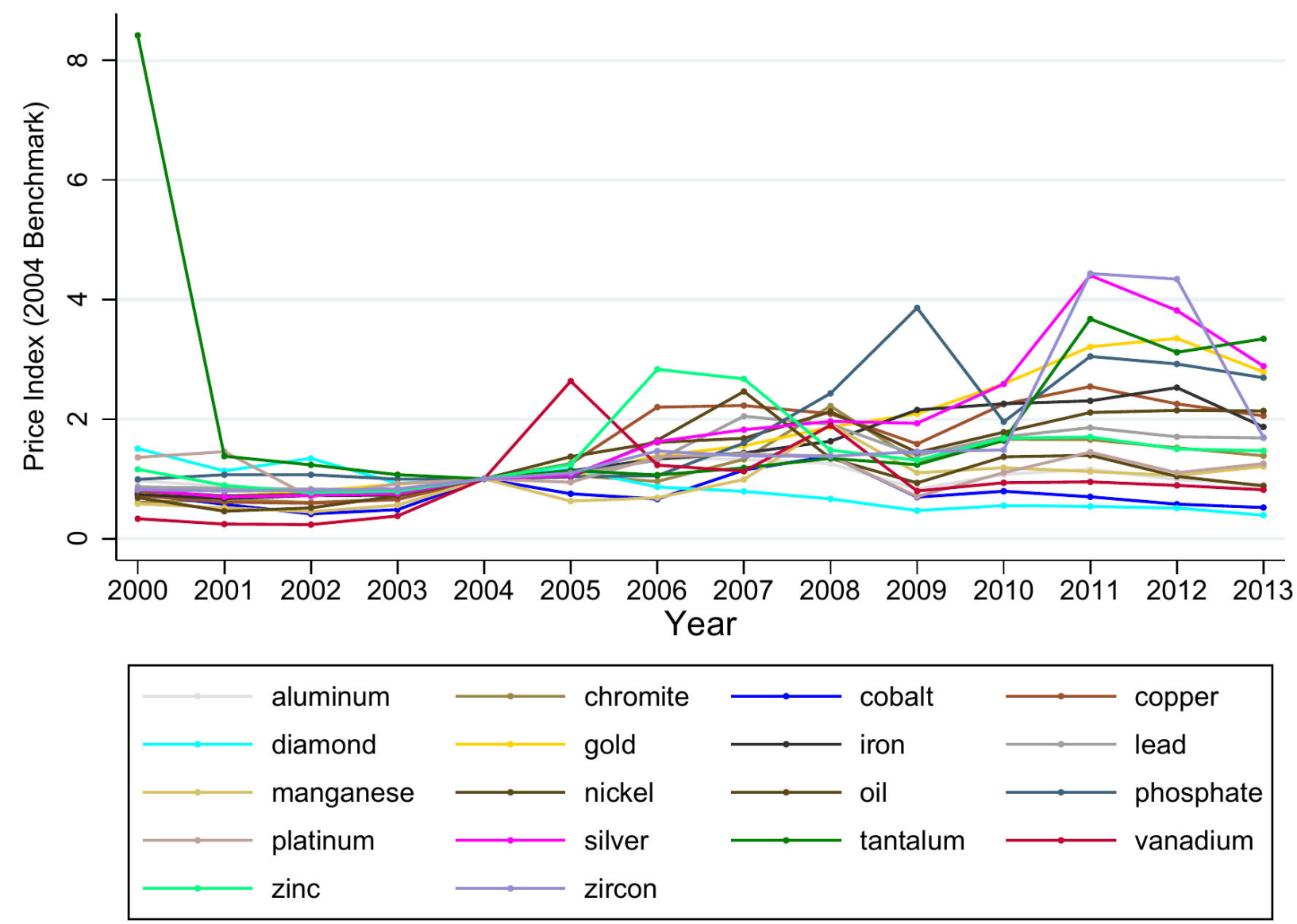

Notes: This figure shows world commodity prices from 2000 to 2013 . All prices are indexed to 2004 . 


\section{Section IA6: New Firms Entering the Extraction Sector}

In Section 4.3 of the Manuscript, we discuss the role of ownership changes. To assess whether the selection of more productive firms contributes to the observed increase in economic activity, we compare the level of luminosity around mine ownership changes in the post-2004 period, by estimating the following two OLS regressions:

$$
\begin{aligned}
& \operatorname{Ln}\left(\text { Luminosity }_{c, t}+0.01\right)=\sum_{t} \beta_{1} \text { Year Relative to Ownership Change } e_{c, t} \\
& + \text { Fixed Effects }+\varepsilon_{c, t} \\
& \operatorname{Ln}\left(\text { Luminosity }_{c, t}+0.01\right)=\sum_{t} \beta_{1} \text { Year Relative to Ownership Change } e_{c, t} \times \operatorname{Ln}\left(\text { Price }_{m, t}\right) \\
& + \text { Fixed Effects }+\varepsilon_{c, t}
\end{aligned}
$$

In Eq. (IA.2), we examine changes in the level of luminosity (without using world commodity prices as an instrument) and in Eq. (IA.3) we examine extractive activities' contribution to economic growth (by exploiting variation in commodity prices as an instrument for extractive activities). Year Relative to Ownership Change is a set of event-time indicators for each year relative to the ownership change. The other variables and fixed effects are the same as in Eq. (1) in the Manuscript. We limit our sample to mines because we cannot observe ownership changes at the facility level for oil and gas wells. To be included in our sample, we require a mine to experience at least one ownership change after 2004. To simplify the analysis, we further limit the sample to extraction facilities that are subject to the FCPA, which is why FCR is not included in the regression.

In Figure IA6 Panel A, we plot the Year Relative to Ownership Change coefficient estimates. The pattern is inconsistent with the entry of new, more productive firms explaining why economic activity is higher in the presence of foreign corruption regulation. Instead, the figure shows that increases in luminosity are concentrated in the years prior to an ownership change. After an ownership change, luminosity gradually decreases relative to the benchmark year, $t$ - 1 . Similarly, in Figure IA6 Panel B, we do not find evidence that ownership changes drive the higher contribution of resource extraction to economic development.

These results suggest that the observed increase in local economic development following foreign corruption regulation cannot be explained by ownership changes. 
Figure IA6: Foreign Corruption Regulation and Within Extraction Sector Resource Allocation

Panel A: Economic Activity in Extraction Areas

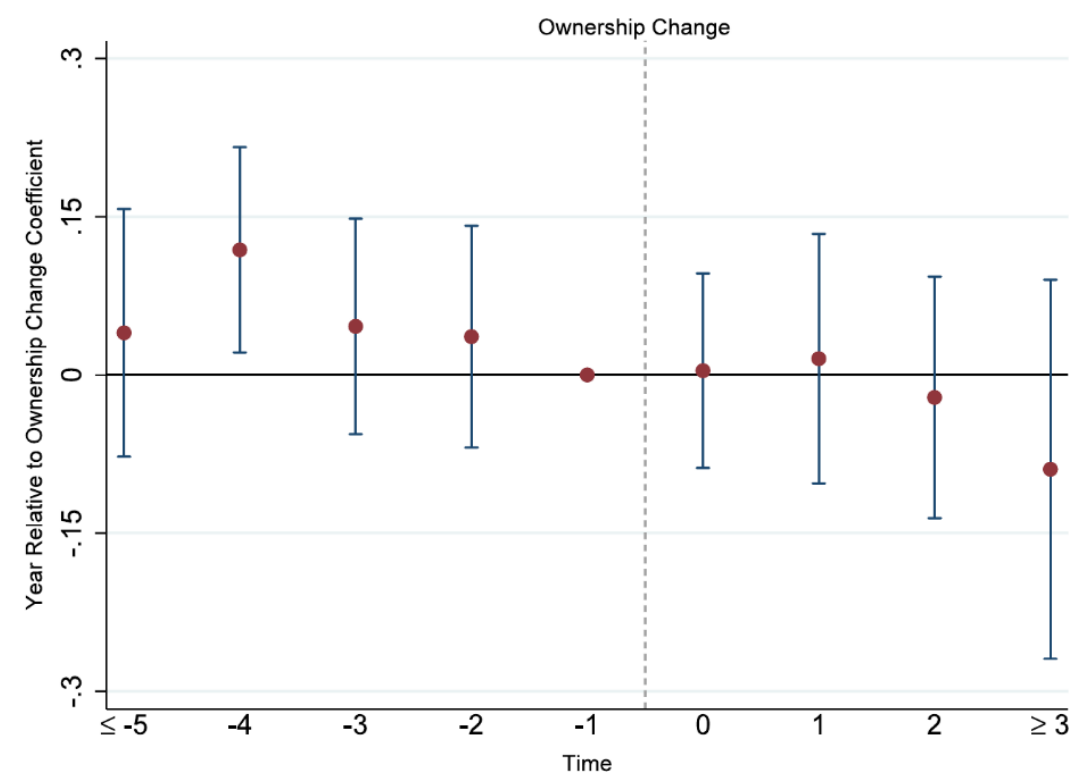

Notes: Panel A shows coefficient estimates and 95\% confidence intervals for OLS regressions examining changes in nighttime luminosity around ownership changes of FCR mines after 2004

Panel B: Contribution of Resource Extraction to Development

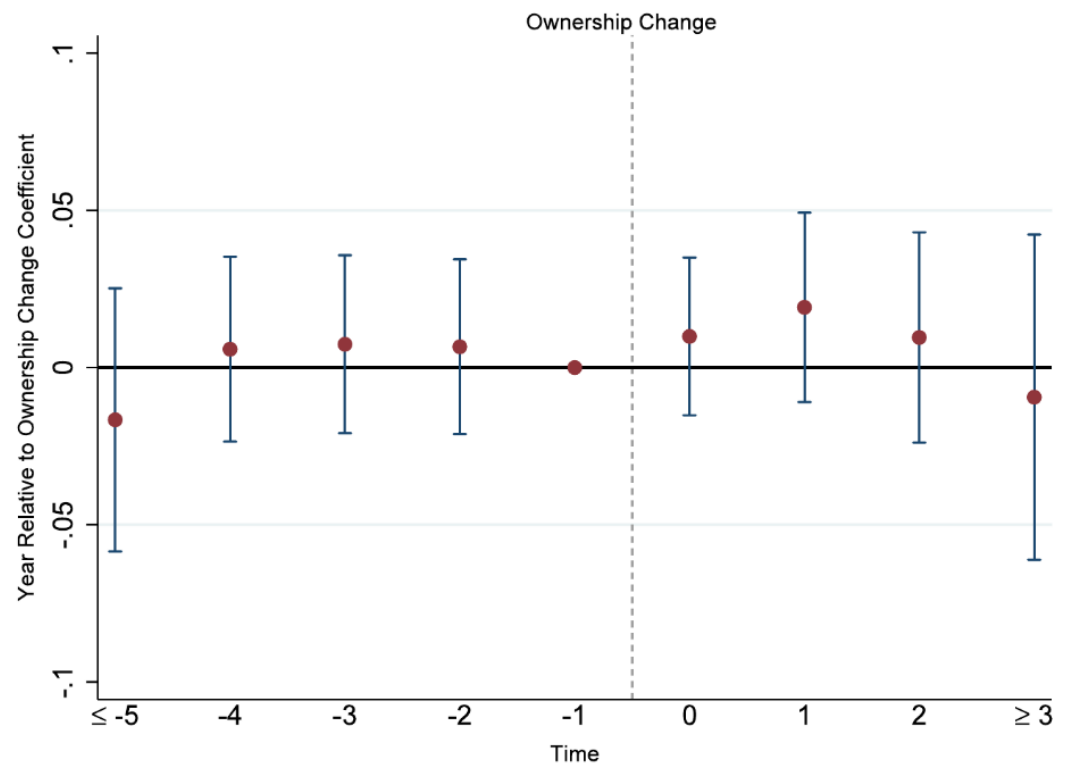

Notes: Panel B shows coefficient estimates and 95\% confidence intervals for OLS regressions examining changes in the association between commodity prices and nighttime luminosity around ownership changes of FCR mines after 2004. 


\section{Section IA7: How Firms Operate without Paying Bribes}

The results in Section 4.3 of the Manuscript raise the question of how, after the enforcement increase, firms subject to the FCPA are able to continue operating in high-corruption-risk areas without paying bribes. One possibility is that firms instead appease local officials by pursuing business practices (that were more expensive than paying a bribe prior to the increase in FCPA enforcement) that are beneficial to the local communities where they operate. For example, in a case study of a large foreign-owned Peruvian gold mining firm, Argon and Rud (2013) find that the existence of strong backward linkages between mining firms and local communities, enabled by a corporate policy aimed at increasing the participation of local firms and workers, led to a more positive association between natural resource extraction and local income growth.

To examine this channel, we look at how foreign extractive firms interact with local African communities in the post-2004 period. We obtain data on local supplier and labor policies of foreign firms from the African Investor Survey of the United Nations Industrial Development Organization (UNIDO). In 2010, UNIDO conducted a large-scale survey among foreign firms with operations in Africa to elicit their investment motives and policies (Boly et al. 2015). Our sample covers the survey responses of 155 foreign extractive firms with investments in 19 African countries. The advantage of the UN survey data is that it allows us to provide direct ground-level evidence on how foreign firms integrate local communities into their operations. The drawback is that the UN conducted this particular survey only once, in 2010, which limits our inferences to cross-sectional comparisons between foreign extractive firms. Moreover, because the survey was fully anonymized, we cannot observe the names of individual companies and assess whether they are under US jurisdiction. As an alternative, we assign treatment based on whether the firm is headquartered in an OECD country and thus is subject to the OECD Anti-Bribery Convention.

We compare local supplier and labor policies between OECD and non-OECD firms in 2010, accounting for host country and subsector fixed effects (i.e., oil/gas extraction, mining, and natural resource refining). In Table IA7, we find that OECD firms operating in Africa are more likely than non-OECD firms to purchase from local suppliers, train local employees, and pay their employees more in 2010 (after the increase in foreign corruption regulation). These results are consistent with the idea that foreign corruption regulation incentivizes firms to pursue business practices that are more beneficial to the local communities where they operate as a substitute for paying bribes. However, because our analysis relies on only one year of cross-sectional data in the post-FCR period (i.e., 2010), we cannot rule out that OECD firms already interacted more with local African communities than non-OECD firms before the increase in FCPA enforcement. Readers should interpret the results in Table IA7 with this caveat in mind. 


\title{
Table IA7: Local Suppliers and Labor Policies of OECD Firms in Africa
}

\author{
Panel A: Descriptive Statistics
}

\begin{tabular}{lrrrrrrrr}
\hline \hline & & & & & & & & \\
& $\mathrm{N}$ & Mean & $\mathrm{SD}$ & $\mathrm{P} 1$ & $\mathrm{P} 25$ & P50 & P75 & P99 \\
\hline OECD & 150 & 0.200 & 0.401 & 0.000 & 0.000 & 0.000 & 0.000 & 1.000 \\
New Local Suppliers Added & 129 & 5.519 & 14.027 & 0.000 & 0.000 & 0.000 & 4.000 & 60.000 \\
Employee Training & 150 & 0.467 & 0.501 & 0.000 & 0.000 & 0.000 & 1.000 & 1.000 \\
Wage Production Workers & 133 & 305.988 & 340.422 & 0.000 & 124.064 & 198.102 & 353.406 & $2,012.516$ \\
Wage Technical Workers & 137 & 976.088 & $1,167.823$ & 0.000 & 297.152 & 598.167 & $1,250.962$ & $6,061.056$ \\
Wage Clerical Workers & 139 & 554.985 & 782.390 & 0.000 & 158.018 & 292.036 & 535.860 & $3,804.607$ \\
\hline
\end{tabular}

Notes: This table presents descriptive statistics for the regression analyses in Table IA7 Panel B. OECD is a binary indicator equal to one if the firm is headquartered in a country that ratified the OECD Anti-Bribery Convention before 2004. New Local Suppliers Added is the number of new local suppliers that have been added to the firm's supplier list during the last three years. Employee Training is a binary indicator equal to one if the firm provides formal internal or external training to its employees. Wage Production Workers is the average monthly wage or salary paid to production workers during the last fiscal year. Wage Technical Workers is the average monthly wage or salary paid to technical, supervisory, or managerial staff during the last fiscal year. Wage Clerical Workers is the average monthly wage or salary paid to clerical or administrative staff during the last fiscal year.

\section{Panel B: Regressions}

\begin{tabular}{|c|c|c|c|c|c|}
\hline Dependent Variable: & $\begin{array}{c}(1) \\
\text { Ln(1+New Local } \\
\text { Suppliers Added })\end{array}$ & $\begin{array}{c}(2) \\
\text { Employee } \\
\text { Training }\end{array}$ & $\begin{array}{c}(3) \\
\text { Ln(1+Wage } \\
\text { Production } \\
\text { Workers })\end{array}$ & $\begin{array}{c}(4) \\
\text { Ln(1+Wage } \\
\text { Technical } \\
\text { Workers })\end{array}$ & $\begin{array}{c}(5) \\
\text { Ln(1+Wage } \\
\text { Clerical } \\
\text { Workers })\end{array}$ \\
\hline$O E C D$ & $\begin{array}{c}0.901 \\
(0.415) \\
\end{array}$ & $\begin{array}{c}0.373 \\
(0.111) \\
\end{array}$ & $\begin{array}{c}0.734 \\
(0.251) \\
\end{array}$ & $\begin{array}{c}0.954 \\
(0.320) \\
\end{array}$ & $\begin{array}{c}0.747 \\
(0.397) \\
\end{array}$ \\
\hline $\begin{array}{l}\text { Fixed Effects: } \\
\text { Host Country } \\
\text { Subsector }\end{array}$ & $\begin{array}{l}\text { Yes } \\
\text { Yes }\end{array}$ & $\begin{array}{l}\text { Yes } \\
\text { Yes }\end{array}$ & $\begin{array}{l}\text { Yes } \\
\text { Yes }\end{array}$ & $\begin{array}{l}\text { Yes } \\
\text { Yes }\end{array}$ & $\begin{array}{l}\text { Yes } \\
\text { Yes }\end{array}$ \\
\hline $\begin{array}{l}\text { Adjusted R-Squared } \\
\text { Firm Observations }\end{array}$ & $\begin{array}{l}0.07 \\
129\end{array}$ & $\begin{array}{c}0.12 \\
150\end{array}$ & $\begin{array}{c}0.14 \\
133\end{array}$ & $\begin{array}{c}0.14 \\
137\end{array}$ & $\begin{array}{c}0.26 \\
139\end{array}$ \\
\hline
\end{tabular}

Notes: This table reports coefficient estimates of OLS regressions examining the local supplier and labor policies of OECD and non-OECD firms in Africa. Standard errors clustered at the firm level are reported in parentheses. $O E C D$ is a binary indicator equal to one if the firm is headquartered in a country that ratified the OECD AntiBribery Convention before 2004. New Local Suppliers Added is the number of new local suppliers that have been added to the firm's supplier list during the last three years. Employee Training is a binary indicator equal to one if the firm provides formal internal or external training to its employees. Wage Production Workers is the average monthly wage or salary paid to production workers during the last fiscal year. Wage Technical Workers is the average monthly wage or salary paid to technical, supervisory, or managerial staff during the last fiscal year. Wage Clerical Workers is the average monthly wage or salary paid to clerical or administrative staff during the last fiscal year. 


\section{Internet Appendix References}

Altonji, J. G., Elder, T. E., and Taber, C. R. (2005). "Selection on Observed and Unobserved Variables: Assessing the Effectiveness of Catholic Schools." Journal of Political Economy, 113(1): 151-84.

Aragón, F. M., and Rud, J. P. (2013). "Natural Resources and Local Communities: Evidence from a Peruvian Gold Mine.” American Economic Journal: Economic Policy, 5(2): 1-25.

Boly, A., Coniglio, N. D., Prota, F., and Seric, A. (2015). "Which Domestic Firms Benefit from FDI? Evidence from Selected African Countries." Development Policy Review, 33(5), 615636.

Cassin, L. C. (2018). "When Do Issuers Disclose their FCPA Problems?" The FCPA Blog: https://fcpablog.com/2018/08/29/when-do-issuers-disclose-their-fcpa-problems/.

Christensen, H. B., Maffett, M.G., and Rauter, T. (2020). "Policeman for the World: The Impact of Extraterritorial FCPA Enforcement on Foreign Investment and Internal Controls." Working Paper.

Hodler, R., and Raschky, P. (2014). "Regional Favouritism." Quarterly Journal of Economics, 129(2), 995-1033.

Koehler, M. (2019). "Has the FCPA been Successful in Achieving its Objectives?" University of Illinois Law Review, 2019, 1267-1319.

Mancheri, N.A., Sprecher, B., Deetman, S., Young, S.B., Bleischwitz, R., Dong, L., Kleijn, R., and Tukker, A. (2018). "Resilience in the Tantalum Supply Chain." Resources, Conservation and Recycling, 129, 56-69.

Martin, G., Karpoff, J., Lee, D., and Cooper, J. (2012). "The Foreign Corrupt Practices Act: An Empirical Examination of Enforcement Trends." Working Paper.

Sanseverino, A. (2020). "The Impact of Anti-Corruption Laws: Evidence from the U.K. Bribery Act's Extraterritorial Reach." Working Paper.

U.S. Department of Justice and U.S. Securities and Exchange Commission. (2012). A Resource Guide to the U.S. Foreign Corrupt Practices Act. Washington D.C.: U.S. Department of Justice. Retrieved from: https:/www.justice.gov/criminal-fraud/fcpa-guidance.

Zeume, S. (2017). "Bribes and Firm Value.” Review of Financial Studies, 30(5), 1457-1489. 